\title{
Systematic review of institutional innovation literature: towards a multi-level management model
}

\author{
Hameeda A. AlMalki ${ }^{1}$. Christopher M. Durugbo ${ }^{1}$ \\ Received: 29 April 2021 / Accepted: 5 January 2022 \\ (c) The Author(s), under exclusive licence to Springer Nature Switzerland AG 2022
}

\begin{abstract}
Institutional innovation creates smart institutions that idiosyncratically thrive in a world of exponential change. Through policy-driven interventions and experiential learning, managers of institutions become adept at delivering praxis- and crisisdriven innovations required for survival and success. Similarly, the management of institutional innovation remains an interest in research due to links of this form of innovation to economic growth, and the demands of on-going major socioeconomic transformations due to technological advances, increased occurrences of major crises, and emerging socioeconomic challenges. Accordingly, a key question arising from the literature concerns the range of determinants and priorities that influence institutional innovation for delivering society value. Thus, the onus is on scholarship to capture and advance knowledge for harnessing the potency of institutional innovation. The purpose of this article is to analyse the current state of research on institutional innovation. Using the systematic review methodology, we identify and critically appraise 485 peer-reviewed scientific publications between 1969 and 2021. The review finds key determinants and management priorities with a view to developing a multi-level management model of institutional innovation. Guided by insights from the review, the article sets a research agenda for future management studies of institutional innovation.
\end{abstract}

Keywords Institutional innovation - Institutional change · Knowledge externalities · Economic conditions $\cdot$ Technology $\cdot$ Institutional theory

JEL Classification $\mathrm{O} 310$

Christopher M. Durugbo

mcmillanod@agu.edu.bh

1 Department of Innovation and Technology Management, Arabian Gulf University, Manama, Bahrain 


\section{Introduction}

For institutions like governments and businesses, pressures to stay abreast with social changes and scientific advances in society, serve as the impetus for innovation, ${ }^{1}$ i.e., institutional innovation, which changes not only global competition but also the basis of competition itself within, and between institutions. Existing viewpoints on institutional innovation expand management strategy and policy horizons for institutions to include processes such as supply chain management, product innovation, and customer relationship management. These viewpoints redefine roles and relationships across independent entities to accelerate and amplify learning and to reduce risks (Hagel and Brown 2013; Fuentelsaz et al. 2018; Gretchenko et al. 2018). The institutional innovation perspective also depends on mechanisms for building scalable, long-term trust-based relationships through learning capabilities (Hao and Yunlong 2014; Chittoor et al. 2015; Phornlaphatrachakorn 2019) and increasing awareness of environmental pressures (Chu et al. 2018; Tang et al. 2020a). Consequently, institutional innovation underpins the government, educational, training, and corporate policies that solve complex social problems, particularly through systematic collaborations between government agencies, universities, industries, and users.

In the management literature, the main problem for institutional innovation research remains questions on the legitimacy of institutions (Tingey and Webb 2020) and the necessary characteristics of novel initiatives that address socio-economic challenges such as income inequality (Biurrun 2020). Fittingly, there is on-going and increasing theoretical and empirical interest in the determinants of innovation (Molina-Morales and Mas-Verdu 2008; Li et al. 2020). For this line of inquiry, an important focus is on a working hypothesis that conformance to institutional frameworks underpinned by innovation has the potential to deliver societal value (Ventura et al. 2020; Chebrolu and Dutta 2021). Such frameworks highlight the dynamic nature of institutional environments, context-specific nature of innovations, and proactivity of innovators within institutions. Another area of interest (e.g. Pfister et al. (2021) and Tang et al. (2020b)), lies in understanding the priorities of institutions for managing the increasingly sophisticated policy toolbox used by governments to facilitate institutional innovation for public sector composition, creation of tax credits, investment in indigenous talent, intellectual property strategies, environmental protection regulations, funding for research and enterprise, etc. Here, the emphasis is on the nature of deep innovation and reviews of institutional structures needed to sustain livelihoods during times of historic change (Beunen and Kole 2021; Gongbuzeren et al. 2021; Hughes et al. 2021). In view of these on-going interests, there is a need to review and capture the current state of research

\footnotetext{
1 Innovation is defined here according to the 2018 Oslo Manual as an outcome (business innovation), i.e. "new or improved product or business process (or combination thereof) that differs significantly from the firm's previous products or business processes and that has been introduced on the market or brought into use by the firm", and as a process (innovation activities), i.e. "developmental, financial and commercial activities undertaken by a firm that are intended to result in an innovation for the firm" (OECD/ Eurostat 2018; p. 33).
} 
on institutional innovation regularly for advancing domain knowledge and highlighting paths for future research.

The aim of this article is to review existing literature on institutional innovation based on a systematic approach. The review examines the trends of research methodologies and theories in studies, analyses key determinants, and synthesises management priorities for institutional innovation. Using knowledge captured from the review process, the article proposes a multi-level management model and sets a research agenda that challenges management researchers to advance the field of institutional innovation.

For this review, the interest lies in enriching the on-going work by researchers, managers, and policymakers to analyse the main determinants and priorities of institutional innovation. Such analysis remains critical for two reasons. First, innovation management studies that link institutional factors to economic growth contribute to a wellestablished domain of management research. This domain remains the focus of current studies (Jiang and Zhang 2020; Edwards and King 2021) to underscore the role of new ventures, market creation, inclusivity, and assistance afforded by institutions for the growth of economies and technological trajectory. Here, innovative activities within institutions act a central force to economic growth because they determine sharing rules within society and complement other growth explanations such as frugality, resilience, geography, trade, and capital (Gande et al. 2020; Tomizawa et al. 2020; Nkundabanyanga et al. 2020). Second, the world is at the brink of a major socioeconomic transformation due to the effects of technological revolutions like Industry 4.0, increased occurrences of major crises (e.g., natural disasters, health emergences, regional conflicts, terrorism, and economic recessions), and emerging challenges associated with climate change, rise of populism and geo-political tensions, environmental biodegradation, and rising inequality. Coping with this transformation remains complex and challenging. With thin mind, this review intends to contribute to management research and discourse on institutional innovation based on the rationale that a multi-level management model of institutional innovation could deepen and enhance understanding of determinants and priorities for supporting economic growth and confronting emerging challenges of major socioeconomic transformations. This review confronts the following research question:

RQ What are the main determinants and management priorities of institutional innovation in the literature?

The remainder of this review proceeds as follows. The next section gives an overview of institutional innovation, followed by the review methodology and findings on key determinant and management priorities, respectively. The review then presents the multi-level management model followed by a discussion of potential future questions and challenges for management research on institutional innovation. 


\section{Institutional innovation: an overview}

Institutions are social constructs defined as "the rules of a society or of organisations that facilitate coordination among people by helping them form expectations which each person can reasonably hold in dealing with others" (Ruttan and Hayami 1984, p. 204). These rules govern behaviour, produce more longstanding facets of human systems, and steer societies along specific development paths (McCann 2004; Woodhill 2010) but depend on the will and creativity of individuals (Shaffer 1969). Through formal (e.g. laws) and informal (e.g. social norms) mechanisms, institutions concomitantly emerge from and determine socio-economic exchanges (North 1991; Scott 2006) within public and private spheres of human endeavour. In this context, some researchers argue that 'institutional void', i.e. the absence of formal institutional mechanisms, triggers the use of informal institutional mechanisms for guiding and supporting interactions (Raghubanshi et al. 2021). An alternate view argues that the emergence of institutions stems from constant-cause (same factors) and path-dependence (different factors) explanations (Parrado 2008). Recognising that institutions are 'rules of the game' (North 1990; Edquist 2006; Scott 2006), recent studies (e.g. Chebrolu and Dutta (2021) and Hughes et al. (2021)) argue that radical perturbations, such as the Coronavirus Disease 2019 (COVID-19) pandemic, are 'game changers' that cause socio-economic distress and disrupt the status quo. Yet, these perturbations also pose opportunities for innovation to reimagine existing institutions and to transform the supportive ecosystems of such institutions.

According to Hagel and Brown (2013, p. 4), institutional innovation is a shift from scalable efficiency to scalable learning, such that organisations "can become more adept at generating richer innovations at other levels, including products, services, business models, and management systems". Similarly, Raffaelli and Glynn (2015, p. 409) define institutional innovation as "novel, useful, and legitimate change that disrupts, to varying degrees, the cognitive, normative, or regulative mainstays of an organisational field". For Li et al. (2020b; p.115801), institutional innovation is "the creation of a new and more effective system to encourage people's behaviour, and the realisation of social sustainable development and innovation under the existing production and living environment". This form of innovation emerges from injections of investments and initiatives reinforced by policies and strategies as posited by the 'institutional-pump' model (Durugbo et al. 2020a), which contrasts with technology-push and market-pull theories on innovation (Martin 1994), as summarised by Fig. 1. For instance, 'pumps' of investment underscore directed actions that implement institutional changes proposed via contracts, internalisation, regulation, and referendums (Polopolus 1969; Hug 2005).

Using systems thinking, Johannessen (2008) attempts to explain changes due to institutional innovation along pattern, functional, historical, and cybernetic forms of causal processes. The author suggests these different processes account for legitimacy taken for granted (cognitive) or engrained in social pressures from institutional actors (normative). Similarly, Woodhill (2010) applies a systems 


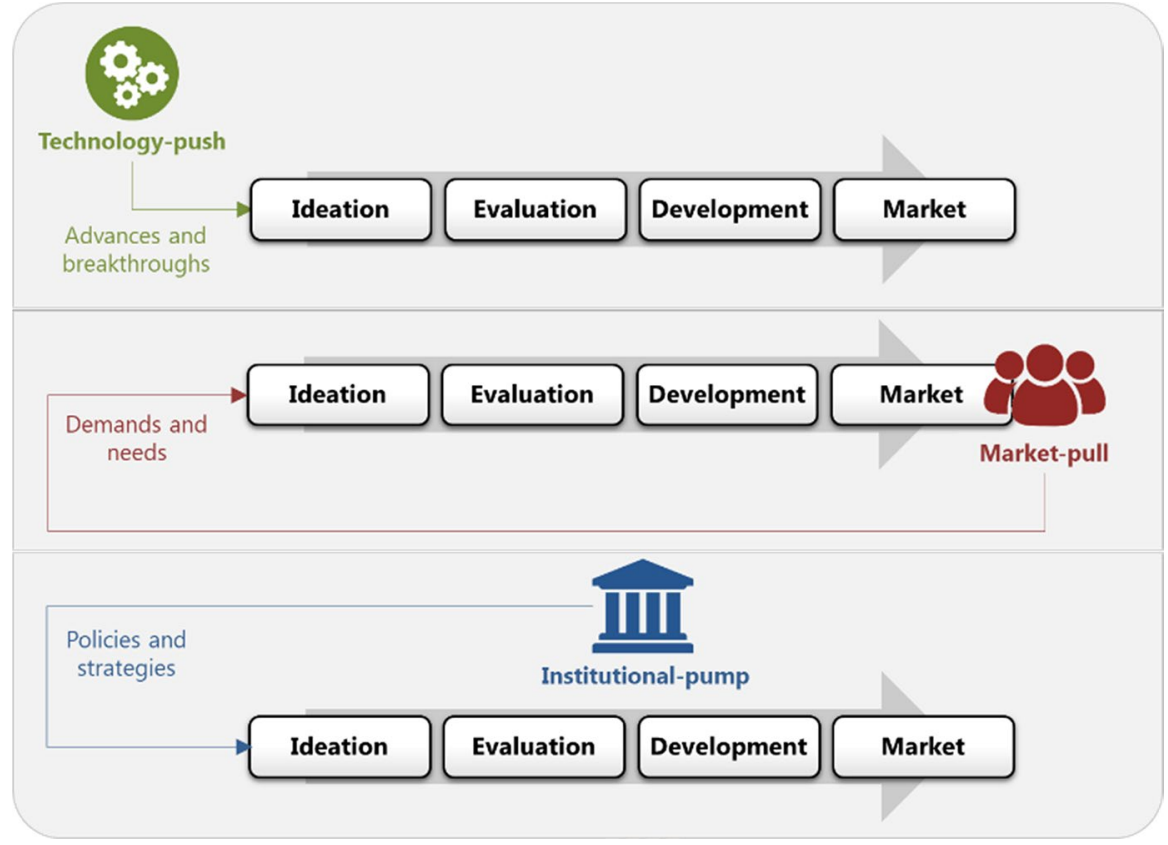

Fig. 1 Comparing the institutional-pump model to technology-push and market-pull theories of innovation (Durugbo et al. 2020a)

complexity standpoint to argue for institutional innovation capacity that involves navigating complexity; learning collaboratively; engaging politically; and being self-reflective. Irrespective of the characterisation, institutional innovation as a concept has some lawful implications for organisational actors. Like other innovations, institutional innovation concerns novelty and utility, but differs in that it is also "legitimate, credible and appropriate" (Raffaelli and Glynn 2015, p. 407). Institutional innovation rose to prominence due to development in sectors such as healthcare and manufacturing, with research on the subject gaining traction in the mid-1970s. Major management changes spurred by research undertaken in England and Wales in 1963 and 1973 as well as in France and North America account for most of this growing interest (Sewell et al. 2005). Here, insights provided from studies over the years underscore how institutions stimulate innovation to reduce uncertainties, coordinate the use of knowledge, mediate conflicts, and provide incentives.

Literature offers three main viewpoints on institutional innovation, as compared by Table 1 . The first viewpoint, induced institutional innovation (Ruttan and Hayami 1984; Ruttan 1989, 2006), posits that resource imbalances due to institutional constraints motivates a dialectic interaction between demand for and supply of innovation. This interaction also considers the influence of technological and cultural changes in society. Here, innovators harness potential opportunities associated with overcoming institutional disequilibrium due to changes in market sizes, government rules, etc. (Grabowski 1991; Godden 1991; Ruttan 2006). The next viewpoint, 
Table 1 Models of institutional innovation in literature

\begin{tabular}{|c|c|c|c|c|}
\hline Models & Overview & $\begin{array}{l}\text { Focus for } \\
\text { innovation }\end{array}$ & $\begin{array}{l}\text { Main institu- } \\
\text { tional trigger }\end{array}$ & Sources \\
\hline $\begin{array}{l}\text { Induced } \\
\text { institu- } \\
\text { tional } \\
\text { innovation }\end{array}$ & $\begin{array}{l}\text { Proposes that } \\
\text { institutional } \\
\text { innovation and } \\
\text { creativity stem } \\
\text { from resource } \\
\text { imbalances and } \\
\text { influences from } \\
\text { technological } \\
\text { and cultural } \\
\text { changes }\end{array}$ & $\begin{array}{l}\text { 'Demand and } \\
\text { supply' } \\
\text { management } \\
\text { strategy }\end{array}$ & $\begin{array}{l}\text { Agents of } \\
\text { change }\end{array}$ & $\begin{array}{l}\text { Davis and North (1970); Farrell } \\
\text { and Runge (1983); Ruttan and } \\
\text { Hayami (1984); Mandal (1987); } \\
\text { Grabowski (1988, 1991); Ruttan } \\
\text { (1989, 2006); Godden (1991); } \\
\text { Lin (1995); Escobal (2000); } \\
\text { McCann (2004); Phakathi et al. } \\
\text { (2021) }\end{array}$ \\
\hline $\begin{array}{l}\text { Continuous } \\
\text { institu- } \\
\text { tional } \\
\text { innovation }\end{array}$ & $\begin{array}{l}\text { Posits that } \\
\text { institutional } \\
\text { improvements } \\
\text { and modernisa- } \\
\text { tions serve to } \\
\text { stay abreast } \\
\text { with continuous } \\
\text { technological } \\
\text { advances and } \\
\text { government } \\
\text { changes }\end{array}$ & $\begin{array}{l}\text { 'As and when' } \\
\text { management } \\
\text { strategy }\end{array}$ & $\begin{array}{l}\text { Scientific } \\
\text { breakthrough }\end{array}$ & $\begin{array}{l}\text { Sha et al. (2006); Tolbert et al. } \\
\text { (2008); Biggs (2008); Fung } \\
\text { (2012); Batukova et al. (2019); } \\
\text { Li et al. (2020); Xie and Yang } \\
\text { (2021) }\end{array}$ \\
\hline $\begin{array}{l}\text { Collective } \\
\text { institu- } \\
\text { tional } \\
\text { innovation }\end{array}$ & $\begin{array}{l}\text { Argues that insti- } \\
\text { tutional changes } \\
\text { and reforms } \\
\text { depend on dif- } \\
\text { ferent fields or } \\
\text { sectors }\end{array}$ & $\begin{array}{l}\text { 'One and all' } \\
\text { management } \\
\text { strategy }\end{array}$ & $\begin{array}{l}\text { Field- } \\
\text { dependent } \\
\text { exchanges }\end{array}$ & $\begin{array}{l}\text { Hargrave and Van De Ven (2006); } \\
\text { de Leeuw and Gössling (2016) }\end{array}$ \\
\hline
\end{tabular}

continuous institutional innovation, notes the rapid advances and waves in technological breakthroughs (Li et al. 2020; Xie and Yang 2021) that improve democratic governance (Biggs 2008; Fung 2012). These breakthroughs emerge from and deliver provisioning in four main forms: (i) technological infrastructure that enact innovative policies; (ii) high technology that engineer complex solutions; (iii) computerbased information systems that enable innovative business processes; and (iv) digital technologies that enhance service delivery (Durugbo et al. 2020a). The third viewpoint, collective institutional innovation (Hargrave and Van De Ven 2006), uses social movement and technology innovation literature to argue for a model of collective action for change that is field-dependent and occurs according to the exchanges between actors within the field. The viewpoint also highlights four perspectives on institutional innovation involving adaption, diffusion, design, and collection action-according to varying actor level foci and reproduction/ construction modes of change.

Institutional innovation is important for accelerating economic activities and contributes to added economic value. This is because this form of innovation shapes the behaviour of organisations (Edquist 2006) and motivates institutional actors to plan modifications that spur a variety of collective activities carefully (Schickler 2001; 
Veiga et al. 2020). Institutions also favour innovation because the process gives rise to stability necessary for fluid knowledge exchanges and learning processes (Carlsson 1997). In discussions concerning the role of innovation for economic growth, recent research accentuates the need to explore selective forms of interventions that support internationalisation in spheres of education (Foray and Woerter 2021; Fumasoli and Rossi 2021), the public sector (Buchheim et al. 2020), and business (Hernández et al. 2021). Some key areas of interest for interventions include fostering innovative work behaviour (AlEssa and Durugbo 2021), and reducing barriers (Hueske and Guenther 2015). Using transformative policies, pro-innovation institutions also attempt to address inequality in economic systems (Biurrun 2020; Perry 2021), manage immigrant integration that boosts cultural diversity (Nyseth and Ventura López 2021), and confront the conflating challenges of energy development and environmental protection (Gao et al. 2020). Yet, institutional innovation is difficult and faces unease, disagreement, and conflict due to the dynamic nature and tension between institutional persistence and innovative change (Hargadon and Douglas 2001). Evidence also suggests that the application of innovation generates additional risks for some institutions (e.g. financial institutions) due to the peculiar complex nature of delivered services (Mishchenko et al. 2021). Furthermore, there are arguments that institutional innovation negatively creates "certain structural and distributional biases" against the backdrop of economic value for institutional actors and participants (Farrell and Runge 1983). Such biases threaten the legitimacy and question the efficacy of the innovation by institutions.

Although, related reviews adopt the systematic approach to review institutional change research (van der Heijden and Kuhlmann 2017; Bakir and Gunduz 2017), the work presented in this article is unique in its focus on institutional innovation. Motivated by the need to deepen knowledge on institutional innovation determinants and priorities, the review presented in this article, seeks to enrich the discourse on factors and actions required for managing institutional innovation and revising existing institutional structures.

\section{Methodology}

Motivated by $R Q$, this article applies the systematic review methodology (Khan et al. 2003) to analyse research studies on institutional innovation. The process for this review, shown in Fig. 2, consists of three main phases: planning, conducting, and reporting (Kitchenham and Charters 2007; Durugbo et al. 2020b). Planning the review involves creating an initial protocol that concretises and formalises the review plan. Table 2 outlines the review protocol concerning the context for the research, the specific research questions, the planned search strategy, and the criteria for publication selection.

Conducting the review is the phase entailing the selection of studies, quality assessment to include studies, data extraction and monitoring, and the data synthesis. Selection concentrates on sources available on two online databases. First, Scopus (https://www.scopus.com), which is a scientific search engine with 


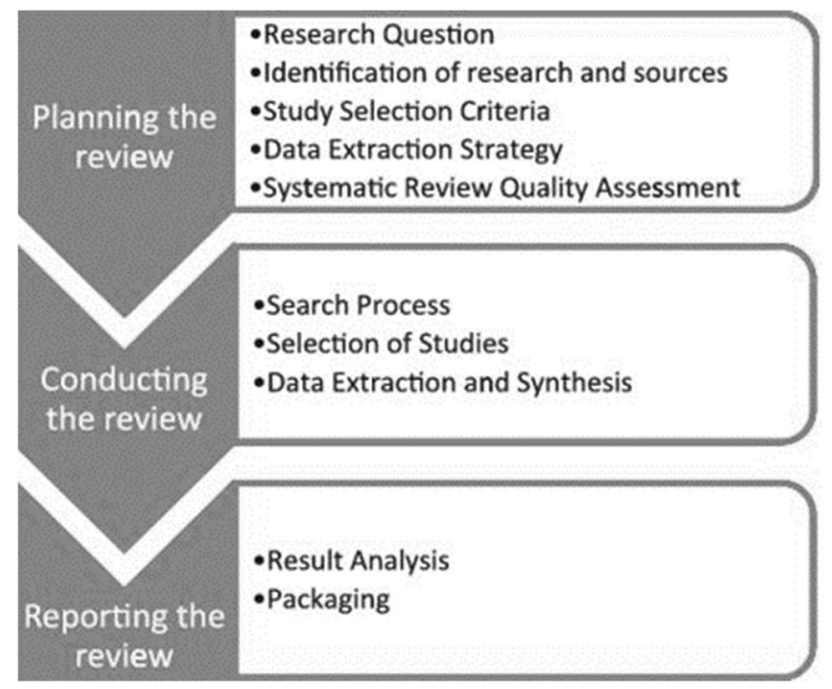

Fig. 2 Systematic literature review process (Kitchenham and Charters 2007)

Table 2 Systematic literature review protocol

\begin{tabular}{|c|c|c|}
\hline Review elements & Descriptions & Foci in the review \\
\hline Purpose & Aim of the literature review & $\begin{array}{l}\text { To review existing literature on institu- } \\
\text { tional innovation }\end{array}$ \\
\hline Search strategy & $\begin{array}{l}\text { Course of action or plan to inform the } \\
\text { search process for the review }\end{array}$ & $\begin{array}{l}\text { The search strategy for the review } \\
\text { involves using keywords to search } \\
\text { specified database and informed by } \\
\text { screening and exclusion criteria }\end{array}$ \\
\hline Search string & $\begin{array}{l}\text { Joining of key words used to conduct } \\
\text { the search for literature }\end{array}$ & $\begin{array}{l}\text { The research strings for the review are } \\
\text { "Institution AND innovation", "innova- } \\
\text { tion AND institution", "institution inno- } \\
\text { vation", OR "institutional innovation" }\end{array}$ \\
\hline Database & $\begin{array}{l}\text { Independent online database with } \\
\text { citation data and indexes of scholarly } \\
\text { writings }\end{array}$ & $\begin{array}{l}\text { The databases used for the review are } \\
\text { Scopus } \\
\text { Web of Science }\end{array}$ \\
\hline $\begin{array}{l}\text { Screening and } \\
\text { Inclusion } \\
\text { criteria }\end{array}$ & $\begin{array}{l}\text { Requirements for selecting and includ- } \\
\text { ing review sources }\end{array}$ & $\begin{array}{l}\text { The searching criteria for the review are } \\
\text { as follows } \\
\text { Empirical and theoretical peer-reviewed } \\
\text { journal articles } \\
\text { Limited to management studies } \\
\text { Research on 'institutional innovation' } \\
\text { concept and challenges }\end{array}$ \\
\hline Exclusion criteria & $\begin{array}{l}\text { Requirement for skipping publications } \\
\text { during the review process }\end{array}$ & $\begin{array}{l}\text { The exclusion criteria for the review are } \\
\text { as follows } \\
\text { Duplicates } \\
\text { Conferences proceeding paper, master's } \\
\text { thesis, doctoral dissertations, text- } \\
\text { books, unpublished working papers } \\
\text { Articles that use the term 'institutional } \\
\text { innovation' or 'institution innovation' } \\
\text { beyond the scope of management }\end{array}$ \\
\hline
\end{tabular}


the most inclusive coverage of published peer-reviewed research. The database provides access to over 26,000 + scientific, technical, and medical (STM) journal titles from over $7000+$ publishers. Second, Web of Science (www.webofscience. com), which is a citation database that tracks and provides access to over 171 million records with about 1.9 billion cited references. Using Scopus and Web of Science, the review identifies, screens, and accumulates sources related to institutional innovation. The search process for the review applies a range of search strings to identify and screen sources based on titles, keywords, and abstracts of articles. The specific strings that serve as the basis for this review are "institution AND innovation", "innovation AND institution", "institution innovation", and "institutional innovation". This search generated 1600 and 1515 results on Scopus and Web of Science respectively, and further refined searches limiting results to journal articles published in English produced 983 and 893 results on Scopus and Web of Science, respectively. Cross-referencing to identify duplicates and screening for relevance yielded 485 articles published between 1969 and 2021 that serve as the basis for this review. Figure 3 shows the yearly distribution of the review articles, indicating a growing trend and interest in the topic, particularly in the past 7 years. The review relies on empirical and theoretical peer reviewed journal articles as the main inclusion criteria. Consequently, this process excludes conference proceeding papers, doctoral dissertations, master's theses, textbooks, and unpublished working papers.

For reporting the review, data analysis initially presents trends and classifications of studies. This phase derives data from preceding steps to inspect, clean, transform, and model review data on methodologies and theories within studies. Figure $4 \mathrm{a}$ shows that the main methodologies used in the literature are case studies (171 articles), econometric models based on longitudinal panel data (111 articles), surveys based mainly on cross-sectional data (52 articles), and essays

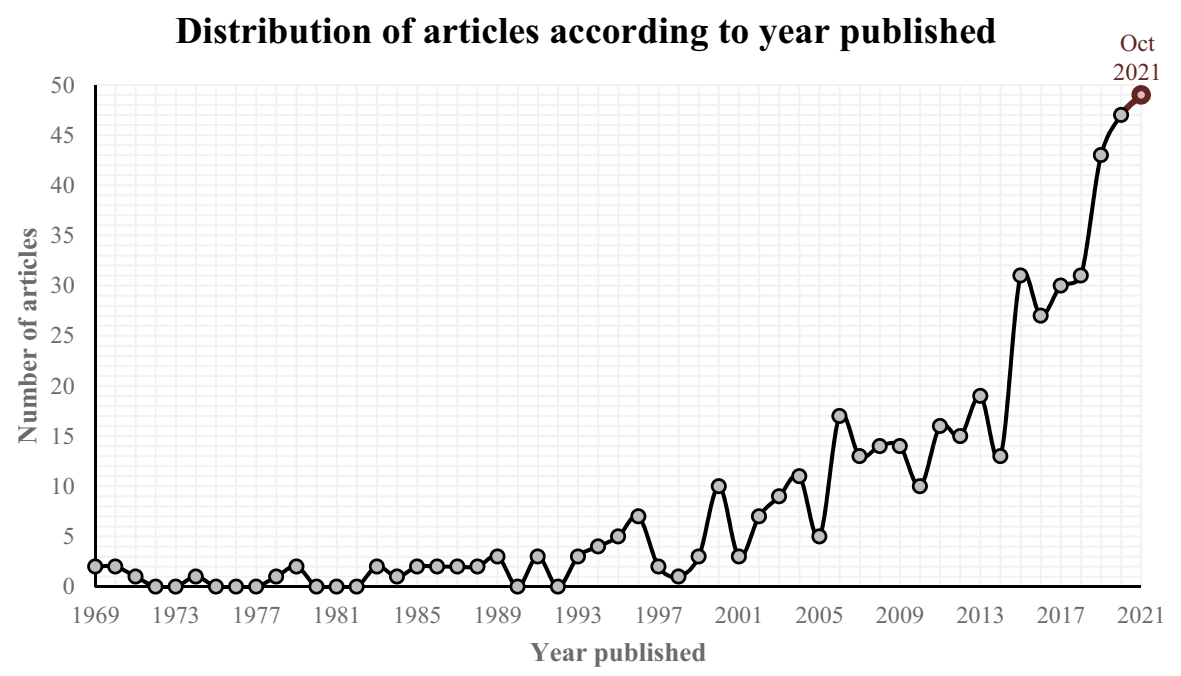

Fig. 3 Yearly distribution of institutional innovation publications 


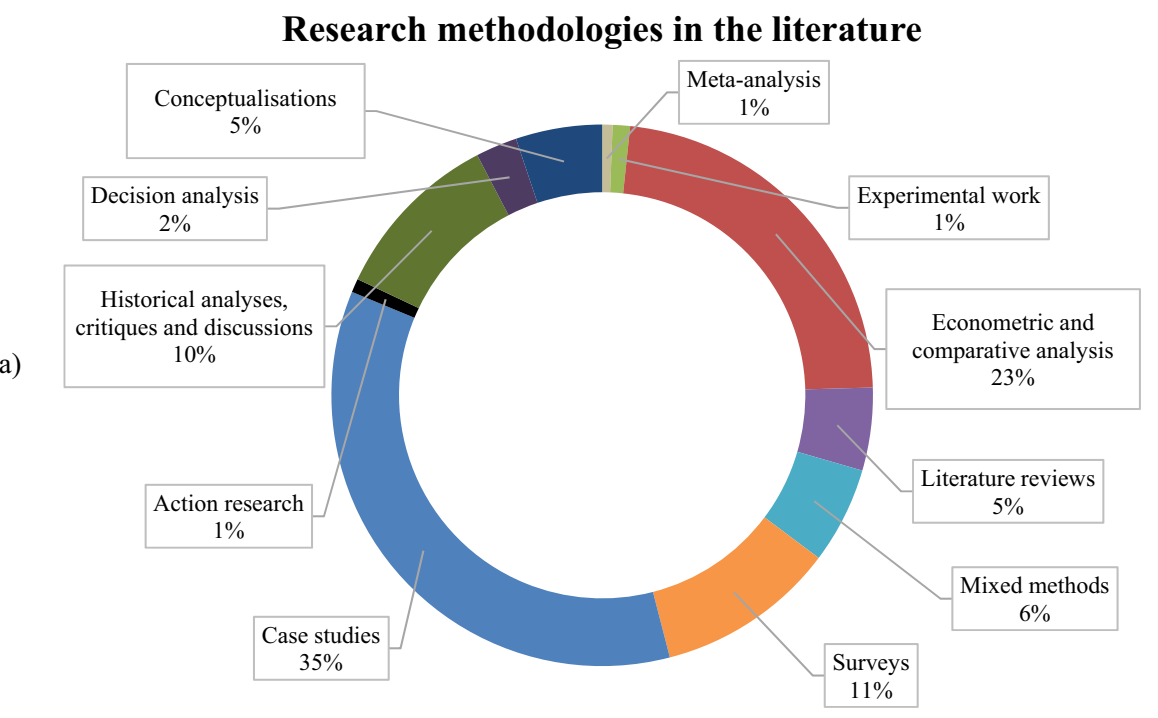

\section{Management theories in the literature}

(b)
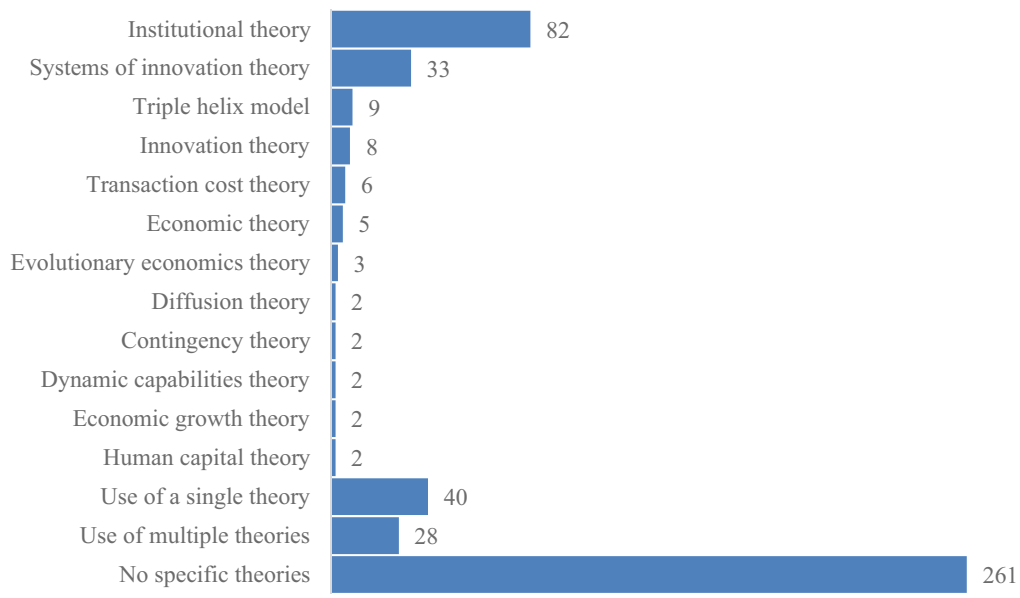

Fig. 4 Analysis of review data according to $\mathbf{a}$ methodologies and $\mathbf{b}$ management theories used in studies

involving critiques, discussions, and historical analyses (50 articles). The review also contains studies using mixed methods (29 articles), literature reviews (24 articles), conceptual pieces (25 articles), decision analysis using techniques such as simulation and multi-criteria decision analysis (12), experimentation (5 articles), action research (4 articles), and meta-analysis (3 articles).

The analysis also finds, as shown in Fig. 4b, strong theoretical underpinnings for institutional innovation studies, with institutional theory, rather unsurprisingly, dominating coverage with use in 95 sources (82 usages in isolation and 
an additional 13 usages from the 28 studies with multiple theories). Some other theories used in the literature include systems of innovation, transaction cost, resource-based view, absorptive capacity, dynamic capabilities, regulatory focus, and social network theories, as presented by Table 3. The reporting phase also involves a synthesis of the findings, consistent with the research protocol, and geared towards presenting the extracted data in a manner that is coherent with

Table 3 Overview of some key management theories in the literature

\begin{tabular}{|c|c|c|}
\hline Theory & Overview & Examples in institutional innovation literature \\
\hline $\begin{array}{l}\text { Institutional } \\
\text { theory }\end{array}$ & $\begin{array}{l}\text { Suggests that homoge- } \\
\text { neity of firm strate- } \\
\text { gies tend to be the net } \\
\text { effect of institutional } \\
\text { pressures }\end{array}$ & $\begin{array}{l}\text { Testing antecedents and effects of environmental innova- } \\
\text { tion (Berrone et al. 2013; Smink et al. 2015; Chen et al. } \\
\text { 2018; Liao 2018; Garrone et al. 2018; la Hiz et al. 2019; } \\
\text { Yao et al. 2021) } \\
\text { Analysing social innovation processes (Kwon and } \\
\text { Motohashi 2017; Turker and Vural 2017; van Wijk et al. } \\
\text { 2019; Raghubanshi et al. 2021) } \\
\text { Exploring relationships between entrepreneurial behaviour } \\
\text { and institutional innovation (Doblinger et al. 2016; } \\
\text { Pinho 2017; Maksimov et al. 2017; Fuentelsaz et al. } \\
\text { 2018; Onsongo 2019) } \\
\text { Examining institutional complexity, constraints, and } \\
\text { complementarities (Lee and Yoo 2008; Sharma et al. } \\
\text { 2010; Zhu et al. 2012; Ma et al. 2015; Wang et al. 2015; } \\
\text { Siltaloppi et al. 2016; Wu et al. 2019; Sena et al. 2021) }\end{array}$ \\
\hline $\begin{array}{l}\text { Systems of inno- } \\
\text { vation theory }\end{array}$ & $\begin{array}{l}\text { Analyses networks of } \\
\text { public and private } \\
\text { institutions in sectors } \\
\text { involved in initiating, } \\
\text { importing, modifying, } \\
\text { and diffusing new } \\
\text { technologies }\end{array}$ & $\begin{array}{l}\text { Conceptualising and empirically studying } \\
\text { Regional innovation systems (Cooke et al. 1997; Fritsch } \\
\text { and Schwirten 1999; Asheim and Coenen 2006; } \\
\text { Oyelaran-Oyeyinka 2006; Li 2015; Fischer and Tello- } \\
\text { Gamarra 2017; Abramov et al. 2019; Lund and Karlsen } \\
\text { 2020) } \\
\text { Sectoral innovation systems (Geels 2004; Rosário et al. } \\
\text { 2013; Kukk et al. 2016) } \\
\text { National innovation systems (Hung 2000; Dodgson 2009; } \\
\text { Hung and Whittington 2011; Watkins et al. 2015; Jiang } \\
\text { and Zhang 2020; Kang and Jiang 2020; Afshari-Mofrad } \\
\text { et al. 2021; Perry 2021) }\end{array}$ \\
\hline $\begin{array}{l}\text { Transaction cost } \\
\text { theory }\end{array}$ & $\begin{array}{l}\text { Posits that governance } \\
\text { structures are deter- } \\
\text { mined by relative } \\
\text { costs for managing } \\
\text { transactions }\end{array}$ & $\begin{array}{l}\text { Analysing institutional responses to technological } \\
\text { advances (Holloway 2000; Dimitri et al. 2009) } \\
\text { Studying the problem of illegal subdivided units, using a } \\
\text { big data approach (Yau and Lau 2018) } \\
\text { Analysing propensity to collaborate (Sena et al. 2021) }\end{array}$ \\
\hline Agency theory & $\begin{array}{l}\text { Suggests that rela- } \\
\text { tionships between } \\
\text { principals and agents } \\
\text { should reflect efficient } \\
\text { organisation of } \\
\text { information and risk- } \\
\text { bearing costs }\end{array}$ & $\begin{array}{l}\text { Assessing the dynamics of institutional relations and } \\
\text { behaviour (Ross 1989; Lui et al. 2016) } \\
\text { Analysing institutional responses to technological } \\
\text { advances (Hoskisson et al. 2002; Dimitri et al. 2009) }\end{array}$ \\
\hline $\begin{array}{l}\text { Resource based } \\
\text { view }\end{array}$ & $\begin{array}{l}\text { Proposes that hetero- } \\
\text { geneity of firm level } \\
\text { capabilities induces } \\
\text { disparities in com- } \\
\text { petitiveness }\end{array}$ & $\begin{array}{l}\text { Testing antecedents and effects of environmental innova- } \\
\text { tion (Nikolaou et al. 2010; Aragon-Correa and la Hiz } \\
\text { 2016; Chen et al. 2018; Mohsen et al. 2021) } \\
\text { Examining enablers for institutional innovation (Wu et al. } \\
\text { 2019; Saka-Helmhout et al. 2020) }\end{array}$ \\
\hline
\end{tabular}


Table 3 (continued)

\begin{tabular}{|c|c|c|}
\hline Theory & Overview & Examples in institutional innovation literature \\
\hline $\begin{array}{l}\text { Social capital } \\
\text { theory }\end{array}$ & $\begin{array}{l}\text { Predicts that social } \\
\text { relationships are } \\
\text { resources that shape } \\
\text { how far an individual } \\
\text { establishes power and } \\
\text { influence }\end{array}$ & $\begin{array}{l}\text { Analysing the social ties of institutional entrepreneurs } \\
\text { (Chen et al. 2021) } \\
\text { Examining legitimacy and trust of social open innovation } \\
\text { (Didenko et al. 2020) }\end{array}$ \\
\hline $\begin{array}{l}\text { Contingency } \\
\text { theory }\end{array}$ & $\begin{array}{l}\text { Posits that effective } \\
\text { actions are reliant on } \\
\text { contexts and situations }\end{array}$ & $\begin{array}{l}\text { Exploring the influence of technological innovations } \\
\text { (Fritsch 2015; Phornlaphatrachakorn 2019; Mohsen } \\
\text { et al. 2021) }\end{array}$ \\
\hline $\begin{array}{l}\text { Innovation diffu- } \\
\text { sion theory }\end{array}$ & $\begin{array}{l}\text { Measures individual } \\
\text { perception of innova- } \\
\text { tion using constructs } \\
\text { of relative advantage, } \\
\text { ease of use/complexity, } \\
\text { visibility, compatibility, } \\
\text { results demonstrability, } \\
\text { image, and voluntariness } \\
\text { of use }\end{array}$ & $\begin{array}{l}\text { Analysing the adoption of technology and quality } \\
\text { standards (Wang and Swanson 2007; Kasperavičiūtè- } \\
\text { Černiauskienè and Serafinas 2018) }\end{array}$ \\
\hline $\begin{array}{l}\text { Dynamic capabili- } \\
\text { ties theory }\end{array}$ & $\begin{array}{l}\text { Suggests that dyna- } \\
\text { mism of firm level } \\
\text { capabilities induces } \\
\text { disparities in com- } \\
\text { petitiveness }\end{array}$ & $\begin{array}{l}\text { Exploring institutional and human capital factors that } \\
\text { influence innovation performance (Asiedu et al. 2020; } \\
\text { Zapata-Cantu and González 2021) }\end{array}$ \\
\hline Triple helix model & $\begin{array}{l}\text { Analyses innovation- } \\
\text { based triple-helix } \\
\text { collaboration between } \\
\text { university, industry, } \\
\text { and government }\end{array}$ & $\begin{array}{l}\text { Studying the role of higher education institutions within } \\
\text { helix innovation networks (García and Velásquez 2013; } \\
\text { Gretchenko et al. 2018; Gachie 2020) }\end{array}$ \\
\hline $\begin{array}{l}\text { Social network } \\
\text { theory }\end{array}$ & $\begin{array}{l}\text { Analyses individual } \\
\text { and organisational } \\
\text { interactions within } \\
\text { the context of larger } \\
\text { relational structures }\end{array}$ & $\begin{array}{l}\text { Investigating network influences of formal and informal } \\
\text { ties (Gao et al. 2017; Wang et al. 2019b) }\end{array}$ \\
\hline $\begin{array}{l}\text { Absorptive capaci- } \\
\text { ties theory }\end{array}$ & $\begin{array}{l}\text { Suggests the inno- } \\
\text { vativeness and } \\
\text { flexibility of firms is } \\
\text { shaped by abilities for } \\
\text { recognising, assimi- } \\
\text { lating, transforming, } \\
\text { and applying valuable } \\
\text { external knowledge }\end{array}$ & $\begin{array}{l}\text { Assessing links between institutional forms and innova- } \\
\text { tion performance (Foray and Woerter 2021) }\end{array}$ \\
\hline $\begin{array}{l}\text { Actor network } \\
\text { theory }\end{array}$ & $\begin{array}{l}\text { Proposes heterogeneous } \\
\text { networks consisting } \\
\text { of social and techno- } \\
\text { logical nodes }\end{array}$ & $\begin{array}{l}\text { Understanding the logic for institutional innovation } \\
\text { (Waldorff 2013) }\end{array}$ \\
\hline $\begin{array}{l}\text { Cultural dimen- } \\
\text { sions theory }\end{array}$ & $\begin{array}{l}\text { Measures differences } \\
\text { in culture according } \\
\text { to individualism/ } \\
\text { collectivism, power } \\
\text { distance, uncertainty } \\
\text { avoidance, and mas- } \\
\text { culinity/femininity }\end{array}$ & $\begin{array}{l}\text { Exploring cultural differences on the proactivity of institu- } \\
\text { tions for innovation (Bennett and Nikolaev 2020) }\end{array}$ \\
\hline
\end{tabular}


Table 3 (continued)

\begin{tabular}{|c|c|c|}
\hline Theory & Overview & Examples in institutional innovation literature \\
\hline $\begin{array}{l}\text { Normalisation } \\
\text { process theory }\end{array}$ & $\begin{array}{l}\text { Posits on factors that } \\
\text { foster and inhibit the } \\
\text { embeddedness of } \\
\text { complex interventions } \\
\text { in everyday tasks }\end{array}$ & $\begin{array}{l}\text { Exploring enablers for social innovation (Windrum et al. } \\
\text { 2018) }\end{array}$ \\
\hline $\begin{array}{l}\text { Resource-depend- } \\
\text { ency theory }\end{array}$ & $\begin{array}{l}\text { Argues that organi- } \\
\text { sational behaviour } \\
\text { must be understood } \\
\text { in the context of } \\
\text { that behaviour with } \\
\text { regards to distribution } \\
\text { of power and control } \\
\text { within/outside the } \\
\text { organisation }\end{array}$ & $\begin{array}{l}\text { Analysing the social ties of institutional entrepreneurs } \\
\text { (Chen et al. 2021) }\end{array}$ \\
\hline $\begin{array}{l}\text { Regulatory focus } \\
\text { theory }\end{array}$ & $\begin{array}{l}\text { Posits on motivational } \\
\text { regulation and pro- } \\
\text { cesses according to } \\
\text { promotion that moti- } \\
\text { vates individuals to } \\
\text { minimise the discrep- } \\
\text { ancies between their } \\
\text { actual and desired } \\
\text { states, and prevention } \\
\text { that motivates indi- } \\
\text { viduals to maximise } \\
\text { the discrepancies } \\
\text { between their actual } \\
\text { and undesired states }\end{array}$ & $\begin{array}{l}\text { Examining the influence of promotion and prevention foci } \\
\text { on institutional innovation (Cowden and Bendickson } \\
\text { 2018) }\end{array}$ \\
\hline $\begin{array}{l}\text { Social identity } \\
\text { theory }\end{array}$ & $\begin{array}{l}\text { Proposes that social } \\
\text { groups give their } \\
\text { members orientations } \\
\text { for self-reference and } \\
\text { establish the mem- } \\
\text { bers' place in society }\end{array}$ & $\begin{array}{l}\text { Modelling collective action for institutional change (Har- } \\
\text { grave and Van De Ven 2006) }\end{array}$ \\
\hline Systems theory & $\begin{array}{l}\text { Argues that order } \\
\text { naturally emerges } \\
\text { in organisations } \\
\text { as resources are } \\
\text { exchanged with their } \\
\text { environments }\end{array}$ & $\begin{array}{l}\text { Analysing blends of entrepreneurial and institutional } \\
\text { endeavours within ecosystems for innovation (Jucevicius } \\
\text { et al. 2016) }\end{array}$ \\
\hline
\end{tabular}

the review objective and intended outcomes (Kitchenham and Charters 2007). Synthesis during the review is descriptive and intended to present clusters and outlines of the key determinants and management priorities for institutional innovation. In establishing the determinants, the review creates categories of concepts that serve as the phenomena investigated. For management priorities, the review applies clustering to capture themes that underscore focal points for management and interventions to enhance institutional innovation. Applying conceptual and thematic analysis is consistent with the systematic review methodology (Khan 
et al. 2003; Durugbo 2020) and enables the review to present the findings in a form suitable for dissemination. The next section reports the findings of the synthesis of articles.

\section{Main determinants of institutional innovation}

Literature suggests institutional innovation management exists in four main contexts: organisational, environmental, social, and governmental. These innovation contexts strengthen the contribution of intangible resources (e.g., proximity, relational capital, cooperation, and learning) as sources of economic growth. Constructs such as the quadruple helix (Schütz et al. 2018), ${ }^{2}$ posit on actors and systems for these contexts with institutions pursuing radical (Gao et al. 2015; Martínez-Pérez et al. 2019; Qing et al. 2019; Ventura et al. 2020), incremental (Vermeulen et al. 2007b), and in some cases, frugal (Kunamaneni 2019; Ananthram and Chan 2021; Jayabalan et al. 2021) innovations.

Organisational innovation presents the core context for institutional innovation, harnessing the potentials of open and technological innovations, and delivering breakthrough processes and products in areas such as healthcare (Laurell 2018), finance (Boulanger and Gagnon 2018), and education (Sein-Echaluce et al. 2017; Boroujerdi et al. 2020; Thani et al. 2021). Delving into complexities of intra- and inter-organisational innovation underlines the significance of new ventures and enterprise (Fuentelsaz et al. 2018), innovativeness and innovative behaviour (Sun et al. 2017; Da Silva 2019), and innovative investment and funding (Huston et al. 2015) for sustaining economic growth of cities and communities. With increasing awareness of an emergent environmental crisis, institutions also pursue environmental (green and eco forms of) innovations aimed at sustainable development (Adomssent and Michelsen 2006; Wang et al. 2019a). Eco-friendly energy sources (e.g., solar, hydro and wind) and practices (e.g. reverse logistics) afford institutions with opportunities for enhancing nature's resilience to environmental pressures and for promoting responsible and accountable use of natural resources (Huang and Yang 2014; Polzin et al. 2016; Chen et al. 2018). This context motivates studies of management strategies such as stringent environmental regulations (Chu et al. 2018; Yao et al. 2019), reverse logistics (Aguilera-Caracuel and Ortiz-de-Mandojana 2013; Huang and Yang 2014), brand equity (Yao et al. 2021), and mobilisation of private finance (Polzin et al. 2016). Additionally, institutions chase social innovations in efforts to address complex social problems such as income inequality, poverty alleviation, urban mobility, and persistent societal and endemic violent conflicts. The intent is to create societal value (Turker and Vural 2017) and promote social enterprise (Kolk and Lenfant 2015; Venugopal and Viswanathan 2019) in conflict-affected areas plagued by institutional gaps. Co-creating and legitimating social innovation (Onsongo 2019; Kumari et al. 2020) becomes paramount as institutions explore agents of social change for sectoral diffusion patterns (Peirce 1991; Windrum et al. 2018) along with empowerment in public welfare for

\footnotetext{
${ }^{2}$ Network of actors from academia, industry, government, and the public.
} 
marginalised citizens and local communities that creates opportunities for positive change (Andersen and Bilfeldt 2017). Governmental (regulatory or policy (CostaFont and Puig-Junoy 2007)) innovation involves initiatives by governments that seek to confront discrepancies between the existing and attainable quality of life for citizens (Shaffer 1969). These discrepancies stem from issues surrounding employability, inequality in advanced economies, over-concentration of wealth for few at the top of the income distribution (Biurrun 2020; Fumasoli and Rossi 2021). Examples of policy innovations include the New Deal legislation of the 1930s that generated economic value in the form of reduced risk and increased rewards for farmers (Farrell and Runge 1983) and the Federal Reserve Act of 1913 for supporting bankers (Ferderer 2003). Intergovernmental bodies also implement policy innovation, e.g., the Birds and Habitats Directives that targets the sustainable conservation of natural habitats and species (Beunen and Kole 2021). Traditionally the mode for socioeconomic advances by contemporary societies (Rickards et al. 1996; Tingey and Webb 2020), recent studies highlight the increasing use of innovative policy toolboxes by local, national, and regional governments of emerging economies (May 2008; Helleiner and Wang 2018; Tang et al. 2020b) for boosting collaboration (Gachie 2020) and effectiveness (Rodríguez-Pose and Zhang 2020).

In view of these contexts, this analysis of the literature identifies four categories of determinants for institutional innovation: (i) institutional quality and control, (ii) institutional diversity and reputation, (iii) institutional value and output, and (iv) institutional reform and improvement. Table 4 summarises these key determinants, and the next subsections outline the main concepts within the categories.

Table 4 Main determinants of institutional innovation

\begin{tabular}{|c|c|c|c|}
\hline Determinants & Overview & Categories & Main concepts \\
\hline \multirow[t]{2}{*}{$\begin{array}{l}\text { Institutional qual- } \\
\text { ity and control }\end{array}$} & $\begin{array}{l}\text { Analysing the efficiency } \\
\text { and dexterity of } \\
\text { innovation inputs }\end{array}$ & Quality & $\begin{array}{l}\text { Institutional support system (Shin 2004; Lobe and Berkes 2004; Xie 2006; } \\
\text { Malva et al. 2013; Lisowska and Stanisławski 2014; Barros 2015; Juk and } \\
\text { Fuck 2015; Ferguson and Carnabuci 2017; Fischer and Tello-Gamarra } \\
\text { 2017; Huang et al. 2017; Salandra 2018; Ervits and Zmuda 2018; } \\
\text { Rodríguez-Pose and Zhang 2020; Ruan and Liu 2021; Mosconi and } \\
\text { D’Ingiullo 2021) } \\
\text { Institutional networks (Fritsch and Schwirten 1999; Bahlmann and Spiller } \\
\text { 2009; Schøtt and Jensen 2016; Schütz et al. 2018) } \\
\text { Legal systems (Yi et al. 2017; Boudreaux 2017) } \\
\text { Strategic leadership (Arun et al. 2020) } \\
\text { Quality assessment systems (Wiklund et al. 2003; Sharma et al. 2010; Egan } \\
\text { 2013; Wu et al. 2016; Kasperavičiūtė-Černiauskienè and Serafinas 2018; } \\
\text { Jun et al. 2021) } \\
\text { Technology use (Wu et al. 2016; Kawabata and Camargo Junior 2020) }\end{array}$ \\
\hline & & Control & $\begin{array}{l}\text { Governance control systems (Doloreux et al. 2007; Lee and Yoo 2008; } \\
\text { Rahman et al. 2009; Yang et al. 2017; Bekhet and Latif 2018; Yang 2018; } \\
\text { Patterson and Huitema 2019; Agarwal 2020; Alamad et al. 2021) } \\
\text { Control policies (Buck and Rath 1970; Harding 2000; Hart 2001; George } \\
\text { and Prabhu 2003; Molnár 2004; Na et al. 2007; Vermeulen et al. 2007a, } \\
\text { b; Vasudeva 2009; Niosi 2010; Liu et al. 2011; Andrew 2012; Doblinger } \\
\text { et al. 2016; Karaulova et al. 2017; Corsini et al. 2018; Kapetaniou et al. } \\
\text { 2018; May and Schedelik 2019; Allen et al. 2020; Oborn et al. 2021) } \\
\text { Internal control system (Ruan and Liu 2021) } \\
\text { Institutional ownership (Cooke and Saini 2010; Yi et al. 2017; Rong et al. } \\
\text { 2017; Asiedu et al. 2020; Bennett and Nikolaev 2020; Kang and Jiang } \\
\text { 2020; Li et al. 2020; Afshari-Mofrad et al. 2021; Sharma and Sharma } \\
\text { 2021; Bentzen et al. 2021; Godlewska 2021; Hussen and Çokgezen 2021) }\end{array}$ \\
\hline
\end{tabular}


Table 4 (continued)

\begin{tabular}{|c|c|c|c|}
\hline Determinants & Overview & Categories & Main concepts \\
\hline \multirow[t]{2}{*}{$\begin{array}{l}\text { Institutional } \\
\text { diversity and } \\
\text { reputation }\end{array}$} & \multirow[t]{2}{*}{$\begin{array}{l}\text { Investigating the status } \\
\text { and heterogeneous } \\
\text { nature of institutional } \\
\text { actors }\end{array}$} & Diversity & $\begin{array}{l}\text { Knowledge externalities (Wu et al. 2015; d'Agostino and Scarlato 2019) } \\
\text { Capabilities (Li 2015; Yeung 2015; Petruzzelli and Rotolo 2015; Aragon- } \\
\quad \text { Correa and la Hiz 2016; Kang and He 2018) } \\
\text { Policies (De Mothe 1995; Kafouros et al. 2015; Arribas 2020) } \\
\text { Technology (Mutenje et al. 2016; Hinings et al. 2018) } \\
\text { Actors (de Zubielqui et al. 2015; van Wijk et al. 2019; Wu and Park 2019) } \\
\text { Partnership (Whitley 2014; Petruzzelli and Rotolo 2015) } \\
\text { Strategy (Drenth 1996; Unger and Zagler 2003; Wu 2013; Sartor and Beam- } \\
\quad \text { ish 2014) } \\
\text { Networking (Van Bockhaven et al. 2015; Smith and Thomas 2015) }\end{array}$ \\
\hline & & $\begin{array}{l}\text { Reputa- } \\
\text { tion }\end{array}$ & $\begin{array}{l}\text { Strategy (Pesti et al. 2019; Kalkabayeva et al. 2021) } \\
\text { Process (Hargrave and Van De Ven 2006; Ottenbacher and Harrington 2009; } \\
\quad \text { Hao and Yunlong 2014; Venugopal and Viswanathan 2019) }\end{array}$ \\
\hline \multirow[t]{2}{*}{$\begin{array}{l}\text { Institutional value } \\
\text { and output }\end{array}$} & \multirow[t]{2}{*}{$\begin{array}{l}\text { Evaluating the fit and } \\
\text { benefit of innovation } \\
\text { outputs }\end{array}$} & Value & $\begin{array}{l}\text { Institutional logic (Cestino and Berndt 2017; Xie et al. 2019) } \\
\text { Network engagement and relationship (Kwan and Chiu 2015; Yang 2016) } \\
\text { Capabilities (Goldsmith 1988; Woodhill 2010; Ito et al. 2016; Barasa et al. } \\
\text { 2017) } \\
\text { Knowledge (De Laurentis 2006; de Zubielqui et al. 2015; Kwan and Chiu } \\
\text { 2015; Boudreau and Lakhani 2016) } \\
\text { Strategy and strategic leadership (Koh 2006; Wallman 2009; Jayabalan et al. } \\
\text { 2021) }\end{array}$ \\
\hline & & Output & $\begin{array}{l}\text { Partnership (Krishnan and Jha 2012; Azadegan et al. 2013; Rosário et al. } \\
\text { 2013; Robin and Schubert 2013; Kolk and Lenfant 2015; Pesti et al. 2019) } \\
\text { Ownership (Kim et al. 2019; Didenko et al. 2020) } \\
\text { Governance (de la Mothe 2004; Wallman 2009; Hu 2014; Vecchi et al. 2015; } \\
\text { Oppong 2016) } \\
\text { Technology (Wiskerke and Roep 2007; Quiroga and Martin 2017; Markey- } \\
\text { Towler 2020; Mohsen et al. 2021) } \\
\text { Economic condition (Kochhar and David 1996; Haggard and Zheng 2013; } \\
\text { Corsi and Prencipe 2019; Kim et al. 2019) } \\
\text { Capabilities (Oi 2004; Kwan and Chiu 2015; Styhre and Remneland- } \\
\text { Wikhamn 2016; Cestino and Berndt 2017; Gehman and Höllerer 2019; Yu } \\
\text { et al. 2020; Khan and Gulati 2021) }\end{array}$ \\
\hline \multirow[t]{2}{*}{$\begin{array}{l}\text { Institutional } \\
\quad \text { reform and } \\
\text { improvement }\end{array}$} & \multirow[t]{2}{*}{$\begin{array}{l}\text { Scrutinising the genesis } \\
\text { and metamorphosis of } \\
\text { institutional arrange- } \\
\text { ments }\end{array}$} & Reform & $\begin{array}{l}\text { Economic condition (Patel and Burra 1994; Kasper 1994; Simpson 2005; } \\
\text { Hoque et al. 2011; McCarthy et al. 2014; Zhang and Putzel 2016; Khan } \\
\text { and Gulati 2021) } \\
\text { Technology (Regan 1993; Rasiah 1996; Clark 2002; Sandberg 2007) } \\
\text { Strategic leadership and orientation (Wang and Swanson 2007; Reed and } \\
\text { Wallace 2015; van der Krabben and Lenferink 2018; Jensen and Fersch } \\
\text { 2019; Widyani 2019) } \\
\text { Logic and institutional forms (Nolan and Xiaoqiang 1999; Lazer et al. 2011; } \\
\text { Waldorff 2013; Jansson et al. 2013; Huang and Ding 2016; Kooijman et al. } \\
\text { 2017; Perry 2021) } \\
\text { Governance (Shang and Fagan 2006; Yoshikawa et al. 2007; Pascucci and } \\
\text { De Magistris 2011; Karaulova et al. 2017; Yang and Al-Sayed 2021) }\end{array}$ \\
\hline & & $\begin{array}{l}\text { Improve- } \\
\text { ment }\end{array}$ & $\begin{array}{l}\text { Capabilities and externalities (Drew 1995; Lee and Yoo 2008; Woodhill } \\
\text { 2010; Karaulova et al. 2017; Sawang et al. 2017; Antonova and Lomakina } \\
\text { 2020) } \\
\text { Governance (Lane 1986; Nakamura and Born 1993; Lee and Yoo 2008; } \\
\quad \text { Ransdell 2019) } \\
\text { Knowledge (Clark 2002; Velho 2004) } \\
\text { Process (Fullerton 1986; Drew 1995; Irlenbusch et al. 2003; De Jong and } \\
\quad \text { Woolthuis 2008; Tao and Jinchuan 2008; Larsen et al. 2011) } \\
\text { Strategy (Villavicencio et al. 2015; Smink et al. 2015; Jayabalan et al. 2021) } \\
\text { Constraints (Hung 2000; Niosi 2010; van Dijk et al. 2011; McCarthy et al. } \\
\text { 2014; Turker and Vural 2017; Onsongo 2019; Ananthram and Chan 2021) }\end{array}$ \\
\hline
\end{tabular}

\subsection{Institutional quality and control}

Topically, the most investigated category of determinants and independent variables is institutional quality and control that influences efficiency and dexterity of 
innovation inputs. Studies focus on institutional quality because empirical evidence suggests this concept influences the ability of firms to acquire advanced technologies (Wu et al. 2016; Kawabata and Camargo Junior 2020) along with the probability, capacity, and intensity of innovation (Rodríguez-Pose and Zhang 2020; Mosconi and D'Ingiullo 2021). Total quality management (TQM) offers a critical paradigm for ensuring quality (Wiklund et al. 2003; Sharma et al. 2010; KasperavičiūtèČerniauskienè and Serafinas 2018) while control is a determinant that investigative studies generally agree on but underscore in varying research foci. Examples of these control foci include institutional gatekeepers (Ferguson and Carnabuci 2017), institutional structures (Fischer and Tello-Gamarra 2017), institutional governance (Bekhet and Latif 2018), and internal control quality (Ruan and Liu 2021). However, the most stressed quality and control determinants are patent systems characterised by high levels of formalism (Barros 2015; Ervits and Zmuda 2018) and intended for managing Intellectual Property Rights (IPR) (Malva et al. 2013; Huang et al. 2017; Hou et al. 2018). An alternative but complementary perspective in the literature identifies ownership as a mechanism for quality (Yi et al. 2017) due to links with strategic human resource management that support innovation-oriented business strategies (Cooke and Saini 2010). Research also suggests that institutional strategies embed control in an array of managerial tools, such as institutional support systems that prioritise quality controls for shaping R\&D efforts within innovation systems, especially in terms of labour productivity and patenting behaviour (Fischer and Tello-Gamarra 2017). In these circumstances, managerial sense-making (Lee and Yoo 2008; Weber et al. 2019) remains essential to achieving sound long-term performance, on which the legitimacy and sustainability of the selective governance constellation rest.

Although researchers agree on the importance of high performing and pro-innovation institutions, the spotlight on quality and control determinants tend to vary. Measuring efficacy and changeability offers the main interest for some researchers (Bennett and Nikolaev 2020; Afshari-Mofrad et al. 2021), while others analyse factors related to innovation performance (Asiedu et al. 2020; Bentzen et al. 2021; Godlewska 2021) or the performance of institutional entities such as firms (Li et al. 2020; Hussen and Çokgezen 2021), and universities (Sharma and Sharma 2021). The latter interest informs the use of analytical constructs like the quadruple helix, which add a layer of network control for engagement (Schütz et al. 2018; Kang and Jiang 2020). This layer taps into huge potentials for high quality collaborative innovation for confronting grand challenges (e.g., climate change and urban mobility) facing modern societies.

\subsection{Institutional diversity and reputation}

Next, institutional diversity and reputation offer the next category of determinants investigated by researchers. Here, the emphasis remains on understanding the roles of heterogeneous (de Zubielqui et al. 2015) and diverse (van Wijk et al. 2019) actors in mobilising the emotional energy and reflexive awareness necessary to disrupt the status quo, generate (and negotiate) alternatives, and embed solutions in institutional 
contexts to produce profound change. Diversity foci vary in several studies with interests including urban diversity (Smith and Thomas 2015), firm-university partnership diversity (Whitley 2014), and environmental technology diversity (AragonCorrea and la Hiz 2016). These authors recognise variations in the idiosyncratic capabilities of firms for acquiring and allocating resources ( $\mathrm{Li} 2015$; Kang and He 2018) and how these capabilities influence the ability of institutions to generate environmental, social, and economic value for stakeholders (Yeung 2015). For some studies, inequality entrenched in long-standing institutional arrangements is a diversity management challenge for strategies to foster gender inclusivity (Krech 2020) and policies to redress social inequality and poverty (Zapata-Cantu and González 2021). More broadly, highlighted as a puzzle for management scholars, understanding the link between institutional innovation and inequality (Biurrun 2020) is a research focus accentuated by recent macroeconomic shocks due to the global financial crisis of 2007-2008 and COVID-19 pandemic. Due to these shocks and radical perturbations, some researchers (Tomizawa et al. 2020; Hughes et al. 2021) differ in their opinions on the role of diversity, arguing for emphasis on alternate inclusive institutional arrangements that foster inequality due to the breakdown of institutions stemming from major socio-economic and technological transformations in society.

In the literature, institutional reputation contains intrinsic ties to diversity $(\mathrm{Wu}$ et al. 2015) and indicates success (d'Agostino and Scarlato 2019). Reputation, in this context, concerns institutional (and organisational) credibility and integrity as viewed by a wide spectrum of stakeholders, including citizens, governmental agencies, customers, and industry. While strong institutional policies build reputation for top-down, up-and-up implementations, focus on organisational level reputation offers a bottom-up, divide-and-conquer alternative. Considering these prospects, researchers examine how carefully considered innovation strategies enable organisations to boost their reputation (Pesti et al. 2019) for attracting top talent (de la Mothe 2004; Dahm et al. 2021), and how institutional information and externalities influence institutional reputation (de Zubielqui et al. 2015).

\subsection{Institutional value and output}

Insights from the literature suggest that the category for institutional value and output offers the most investigated dependent variables for institutional innovation. In the context of institutions, some researchers with 'contributory foci' measure innovation outputs (e.g., using patent numbers and citations (Kim et al. 2019), revenues of new products (Hou et al. 2019), and costs of equity capital (Lui et al. 2016), while arguing that these outputs are part of a multi-faceted structure involving knowledge creation and diffusion (Kwan and Chiu 2015). In contrast, some studies with 'critical foci' investigate the decline of innovative outputs in the context of ties to policy efforts (Kunamaneni 2019), technology use (Mohsen et al. 2021), and the political economy of micro-level institutions (Haggard and Zheng 2013). There are also studies with 'consequential foci' examining the significance of the institutional environment from which organisations operate (Barasa et al. 2017) and the nature of collaboration between institutional entities (e.g., multinational companies 
and small-sized life science companies) for harnessing entrepreneurial and creative capacities (Styhre and Remneland-Wikhamn 2016).

Value, which is more inherently beneficiary-oriented and relational, also preoccupies researchers (Styhre and Remneland-Wikhamn 2016; Cestino and Berndt 2017), for public value creation that enhances the life of citizens (Yang 2016) and customer value propositions in transaction rules that benefit clients, buyers, end-users, and so on (Wallman 2009). Overall, determinants in this category strive for an integration of community indicators and government performance management in an iterative cycle of engagement, legitimacy, and execution, with structural developments across borders between civil society, politics, and administration.

\subsection{Institutional reform and improvement}

Institutional reform and improvement describe a category of determinants essential for transformative processes (i.e., methodical, management and process innovation) within institutions in such a way that different modus operandi and modus vivendi respect human rights, maintain the rule of law, and are accountable to constituents. Primarily the focus of earlier studies (Polopolus 1969; Ruttan and Hayami 1984; Grabowski 1988) and more recent discussions and conceptualisations (Sus 2019; Hughes et al. 2021; Perry 2021), interest in this category centres on discourse surrounding the genesis and metamorphosis of institutions. Earlier works stress the role of agents of change (Ebegbulem 1974; Pred 1978) while more recent expositions give prominence to the implementation of ambitious projects (Williams 2002; Chien 2007), and transparent public-private partnerships (Zhang and Tan 2019; Oppong and Andrews 2020; Yu 2020). Similarly, the nature of change varies among scholars with debates that highlight differing emphasis on socioeconomic and political change (Halpern 2005), change in the new power topology (Clapp et al. 2016), technological change (Mia 2020; Perry 2021), managerial change (Parrado 2008), and technical change for economic development and knowledge acquisition processes (Oyelaran-Oyeyinka 2006; Ruttan 2006). Some studies argue that reform for institutional improvement is crucial, not only to boost quality levels of outputs (Azadegan et al. 2013) but also procedurally to ensure quality exchanges within cooperative networks (Brinckmann 1998). However, other researchers offer a contrasting perspective that considers negative impacts of limits and constraints such as institutional voids in areas of inadequate support (Turker and Vural 2017), triggering a rethinking and reimagining of existing formal institutional frameworks (Onsongo 2019; Chebrolu and Dutta 2021).

Regional policies embed reform and deliver disruptive (hence economic) capabilities and capacities for improvements. In literature, capabilities tend to represent the most essential determinant in institutional innovation (Sawang et al. 2017), and even though this determinant spans different categories of determinants in literature as shown in Table 4, the reform and improvement category heightens the role of capabilities. Insights from policy making and the development of technical standards advance this line of reasoning (Smink et al. 2015) as policy makers wrestle with necessary blends of heterogeneous actions (radical or incremental) (Turker and 
Vural 2017; Ventura et al. 2020), agents (internal or external) (Villavicencio et al. 2015), and arrangements (formal or informal) (Fischer and Tello-Gamarra 2017) for successful innovations. Capacities and other conditions for successful institutional reforms also preoccupy scholars with policy suggestions for eased foreign direct investment (McCarthy et al. 2014) and entrepreneurial endeavours that transcend the institutional constraints of national innovation systems (Hung 2000). Some studies view national and local reform in the context of structural and behavioural logics that legitimise social meanings required for reform and improvement (Lazer et al. 2011; Waldorff 2013; Kooijman et al. 2017), with scholars analysing speeds and directions of radical innovation. Although varied in focus, there is somewhat of a consensus on the role of reform and improvements for realising substantial economic growth, and for overcoming challenges of unemployment, inequality, and deprivation.

\section{Management priorities for institutional innovation}

Synthesis of review data finds six management priorities for enhancing institutional innovation. This review determines these priorities based on appraising management contributions within the literature. These priorities are: (i) network engagement, externalities, and relationships (NEER), (ii) institutional logic, capabilities, and constraints (ILCC), (iii) economic conditions, policies, and intermediaries (ECPI), (iv) institutional strategies, ownership, and governance (ISOG), (v) technology readiness, transfer, and support (TRTS), and (vi) institutional synergies, incentives, and entrepreneurship (ISIE). Table 5 summarises these priorities and the next subsections outline their importance.

\subsection{Network engagement, externalities, and relationships}

The first of the priorities, NEER, reflects the growing significance of managerial social networks for institutional innovation (Kraft and Bausch 2018) in relation to transdisciplinary and interdisciplinary engagement within institutional networks (Blättel-Mink and Kastenholz 2005; Moore 2011) and ecosystems (Boisvert et al. 2013). This thematic group considers dynamics of organisational networks (Hage and Hollingsworth 2000; Schøtt and Jensen 2016), domesticated market networks (Van Bockhaven et al. 2015), inter-organisational relations (Nooteboom 2000), innovation networks (Lyu et al. 2019), connectedness of regional institutions (Liu 2016), networking practices (Minh and Hjortsø 2015), and cohesive networks (Kraft and Bausch 2018). Here, there are management interests in social capital (Nieto and González-Álvarez 2014; Smith and Thomas 2015), social and institutional trust (Audretsch et al. 2018; Didenko et al. 2020), and relationship ties that include managerial ties (Gao et al. 2017; Ventura et al. 2020) and social ties (Chen et al. 2021).

Network partnerships within this theme consider managing interactions in public-private (Kidd 1996; Rosário et al. 2013), state-market (Yu 2020), and industry-academia (Krishnan and Jha 2012) partnerships. Literature also provides other 
Table 5 Management priorities for institutional innovation

\begin{tabular}{|c|c|c|}
\hline Priorities & Description & Focus of management \\
\hline $\begin{array}{l}\text { Network engagement, knowledge } \\
\text { externalities and relationship }\end{array}$ & $\begin{array}{l}\text { Structural and behavioural engagement within networks to } \\
\text { overcome institutional challenges through cooperation } \\
\text { and to achieve common objective }\end{array}$ & $\begin{array}{l}\text { Network engagement based on: } \\
\text { Social capital (Hage and Hollingsworth 2000; Gupta et al. 2003; Pearson and Richardson 2008; } \\
\text { Sanginga et al. 2010; Nieto and González-Álvarez 2014; Van Bockhaven et al. 2015; Minh } \\
\text { and Hjortsø 2015; Liu 2016; Schøtt and Jensen 2016; Audretsch et al. 2018; Kraft and Bausch } \\
\text { 2018; Lyu et al. 2019) } \\
\text { Role of actors (Lynn et al. 1996; Nordberg et al. 2003; Geels 2004; Simmie and Strambach 2006; } \\
\text { Lounsbury and Crumley 2007; Frey et al. 2012; Reed and Wallace 2015; de Leeuw and } \\
\text { Gössling 2016; Siltaloppi et al. 2016; Llopis and D'Este 2016; Sun et al. 2017; Radaelli et al. } \\
\text { 2017; Chen 2018; van Wijk et al. 2019; Lund and Karlsen 2020) } \\
\text { Knowledge externalities and exchanges (Magalhăes 2004; Hamdouch and Moulaert 2006; } \\
\text { González-López 2011; Rolfstam 2012; Berraies et al. 2015; Vines et al. 2015; Chittoor et al. } \\
\text { 2015; Sein-Echaluce et al. 2017; Boudreaux 2017; Salandra 2018; Liao 2018; d'Agostino and } \\
\text { Scarlato 2019; Torres de Oliveira et al. 2020) } \\
\text { Relationships that exist within } \\
\text { Partnerships (Darvas 1997; Kruss 2005; Buszard and Kolb 2011; Krishnan and Jha 2012; Rosário } \\
\text { et al. 2013; Robin and Schubert 2013; Menzies 2013; Kolk and Lenfant 2015; Pesti et al. 2019; } \\
\text { Huber-Stearns et al. 2019) } \\
\text { Ties, treaties, and collaborations (Richardson 1979; Fritsch and Schwirten 1999; Nooteboom } \\
\text { 2000; Balthasar et al. 2000; Watt 2002; Yingbo et al. 2010; Rodima-Taylor et al. 2012; Nieto } \\
\text { and Gonźlez-Álvarez 2014; Nam et al. 2014; Smith and Thomas 2015; Lee and Law 2017; } \\
\text { Vickers et al. 2017; Schütz et al. 2018; Hou et al. 2019; Moon et al. 2019; Kunamaneni 2019; } \\
\text { Ting et al. 2020; Ventura et al. 2020; Chen et al. 2021) } \\
\text { Sector-based and marketting channels (Bello et al. 2004; Pistor 2009; Bhanot et al. 2021; Ric- } \\
\text { comini et al. 2021) } \\
\text { Ecosystems and clusters for innovation (Janssen and Ostrom 2008; Parto 2008; Boisvert et al. } \\
\text { 2013; Jucevicius et al. 2016; Siltaloppi et al. 2016; Quiroga and Martin 2017; Kumari et al. } \\
\text { 2020; Monteiro et al. 2021) }\end{array}$ \\
\hline
\end{tabular}

Institutional logic, capabilities, and $\quad$ Practices, symbolic systems, values, beliefs, and rules for constraints

Economic conditions, policies, and intermediaries

Institutional strategy, ownership, and governance

Technology readiness, transfer, and

Institutional synergies, incentives, and entrepreneurship generating and organising dily activity time and pace generating and organising daily activity, time, and space
to offer meaning social realities within institutions

Current economic position of nations or regions that evolves according to institutional cycles

Strategies for managing institutional actors to ensure long term success while maintaining socioeconomic stability and sustainability

Technology skills, methods, and processes used to achieve institutional goals

Entrepreneurial ventures driven by complementary capabilities and incentivisation within institutions
Logic, design and representation (Hull 1996; van Waarden 2001; Coriat and Weinstein 2002; Baark 2007; Considine and Lewis 2007; Lee and Yoo 2008; Daly 2008; Magnier-Watanabe and Senoo 2009; Colwell and Narayanan 2010; Lindelöf 2011; Lazer et al. 2011; Azadegan et al. Senoo 2009; Colwell and Narayanan 2010; Lindelóf 2011; Lazer et al. 2011; Azadegan et al.
2013; Bin et al. 2013; Waldorff 2013; McCarthy et al. 2014; Bunda et al. 2014; Piana et al. 2013; Bin et al. 2013; Waldorff 2013; McCarthy et al. 2014; Bunda et al. 2014; Piana et al.
2015; Llopis and D'Este 2016; Kooijman et al. 2017; Cestino and Berndt 2017; Vickers et al. 2015; Llopis and D'Este 2016; Kooijman et
2017; Chen et al. 2018; Martin et al. 2018)

Capabilities (Whitley 2000; Kwon et al. 2009; Hsu et al. 2012; Li 2015; Rasiah et al. 2016; Styhre and Remneland-Wikhamn 2016; Aragon-Correa and la Hiz 2016; Gretchenko et al. 2018; Kang and He 2018; Webster and Gardner 2019; Kunamaneni 2019)

and He 2018; Webster and Gardner 2019; Kunamaneni 2019)
Constraints (Bunduchi et al. 2015; Turker and Vural 2017; Malen and Vaaler 2017; Onsongo 2019; Arranz et al. 2021)

Economic conditions (Baker 1989; Zweifel 1995; Heher 2006; Hyvärinen 2006; Vermeulen et al. 2007b; Haggard and Zheng 2013; Sartor and Beamish 2014; Ma et al. 2015; Fritsch 2015; Clark and Monk 2016; Pinho 2017; Yang et al. 2017; Elle 2017; Vickers et al. 2017; Kapetaniou et al. 2018; Yang 2018; Jiang and Yuan 2018; Aziz et al. 2019; Corsi and Prencipe
2019; Kim et al. 2019)

Policies (Epstein 1994; Harding 2000; Hart 2001; George and Prabhu 2003; Molnár 2004; Na et al. 2007; Vermeulen et al. 2007b; Vasudeva 2009; Niosi 2010; Adebowale 2012; Doblinge et al. 2016; Ito et al. 2016; Kwon and Motohashi 2017; Corsini et al. 2018; Kapetaniou et al. 2018; Allen et al. 2020)

Intermediaries (Hüsig and Mann 2010; Ma et al. 2014; Chen et al. 2015; Watkins et al. 2015; Polzin et al. 2016; Landoni 2017; Radaelli et al. 2017)

Strategy (Ross 1989; Drew 1995; Brinckmann 1998; Hage and Hollingsworth 2000; Koh 2006; Wallman 2009; Cooke and Saini 2010; Kitagawa and Robertson 2011; Hung and Whittington 2011; Sartor and Beamish 2014; Villavicencio et al. 2015; Smink et al. 2015; Abramov et al. 2019; Yang et al. 2019; Yano and Shiraishi 2020)

Institutional ownership (Hoskisson et al. 2002; Yi et al. 2017; Sakaki and Jory 2019)

Participatory governance (Whitley 2000; Casper and Matraves 2003; Yoshikawa et al. 2007; Rahman et al. 2009; Genus 2012; Li et al. 2012; Yi et al. 2012; Clausen 2014; Zhang and Putzel 2016; Yang et al. 2017: Elle 2017; Bekhet and Latif 2018; Yang 2018; Huber-Stearns et al. 2019)

Technology readiness (Abrahamson and Rosenkopf 1993; King et al. 1994; Hung 2000; Clark 2002; Nelson and Nelson 2002; Nagamatsu et al. 2006; Wiskerke and Roep 2007; Huston et al. 2015; Lui et al. 2016; Zhang and Putzel 2016; Quiroga and Martin 2017; Nite and Washington 2017; Yau and Lau 2018: Webster and Gardner 2019; Hou et al. 2019; la Hiz et al 2019; Lyu et al. 2019; Markey-Towler 2020; Mishchenko et al. 2021; Xie and Yang 2021; Oborn et al. 2021; Mohsen et al. 2021)

Technology transfer and partnerships (Clark and Clay 1987; Zweifel 1995; Mason and Wagner

1999; Kwon et al. 2009; Lauto et al. 2013; Suzuki 2015; Rosenbusch et al. 2019; Blake 1999; Kwon

Technology support and adaptation (Kikuchi and Hayami 1983; Regan 1993; Orihata and Watanabe 2000; Abereijo et al. 2009; Chhetri et al. 2012; Hsu et al. 2012; Malva et al. 2013; Barros 2015; Juk and Fuck 2015; Ferguson and Carnabuci 2017; Huang et al. 2017; Hinings et al. 2018; Bjornlund et al. 2020; Bierut and Dybka 2021)

Realising synergetic competences through

Collaborative philosophies of co-creation, co-management, and co-decisions (Shackleton and Raunio 2003; Léopold et al. 2019; Casagrande et al. 2021)

Complementarities of roles and arrangements (Gallery and Gordon 2008; Lee and Yoo 2008; Garrick et al. 2011; Corsi and Prencipe 2019; Da Silva 2019; Wu et al. 2020; Cechin et al. 2021) Incentivising institutional actors (Levien 1971; Tyson 1979; Hyvärinen 2006; Carney and Zheng 2009; Jun and Weare 2011; Shu et al. 2016; Qu et al. 2017; Suparjo 2017; Desmet et al. 2020; Tang et al. 2020a; Wang and Deng 2021)

Entrepreneurial mind-sets in institutions (Munene 1995; Hyvärinen 2006; Wang and Swanson 2007; Jun and Weare 2011; Van Wijk et al. 2015; Albertini and Muzzi 2016; Maksimov et al. 2017; Cowden and Bendickson 2018; Laurell 2018; Tumbas et al. 2018; Widyani 2019; Jensen and Fersch 2019; Phornlaphatrachakorn 2019; Etzkowitz et al. 2019; Rahman et al. 2019; Tang et al. 2020b) 
network arrangements in the form of collaborations among industry, university, and research institutions (Yingbo et al. 2010), R\&D collaborations (Hou et al. 2019), helix innovation networks (Schütz et al. 2018), public research institutions (Fritsch and Schwirten 1999), university-industry links (Kunamaneni 2019), and multilevel institutional linkages (Rodima-Taylor et al. 2012). Significant in institutional collaborations and partnerships is the role of institutional actors (Lounsbury and Crumley 2007; Chen 2018) who substantially influence the creation of new practice, innovation capability, commercialisation of new technology, and institutional arrangements. Specifically, research studies allude to network actors such as executive and middle managers (Radaelli et al. 2017), beneficiaries (Llopis and D'Este 2016), fierce competitors (Frey et al. 2012), suppliers (Nordberg et al. 2003), external actors (Sun et al. 2017), and elites (Geels 2004). These salient actors play a role in shaping innovation networks by influencing the preservation of socioeconomic order and investment in innovation. With this in mind, some studies concentrate on the multi-faceted nature of institutional actors through probes of actor perceptions, activities, and diversity (Lynn et al. 1996; van Wijk et al. 2019), institutional learning (Buttoud et al. 2011), and the increasing use of innovation 'offshoring' that creates global innovation networks (Desai 2009).

This theme also prioritises the management of institutional knowledge-related imperatives stemming from network interactions. Example of these imperatives are knowledge externalities (d'Agostino and Scarlato 2019), knowledge spirals (SeinEchaluce et al. 2017), and knowledge acquisition (Rutherford 2001; Chittoor et al. 2015; Liao 2018) that influence innovation orientation. There are also interests in links between knowledge and creativity (Boudreaux 2017), new knowledge bases (Asheim and Coenen 2006; Rolfstam 2012), and the knowledge infrastructure that facilitates knowledge creation, diffusion, and accumulation in institutions (Hamdouch and Moulaert 2006; Gittelman 2006; Iqbal 2021).

\subsection{Institutional logic, capabilities, and constraints}

The second priority is $I L C C$, which encompasses configuration- and proficiencyrelated management for problem solving and optimising decisions under constraints. Contributions in this thematic grouping consider improvements in the configurations of institutional logic (Kooijman et al. 2017; Cinar and Benneworth 2021), institutional logic differences (Azadegan et al. 2013; Llopis and D'Este 2016), interplay of logics (Vickers et al. 2017), service dominant logic (SDL) and servitization (Cestino and Berndt 2017), and legacies (Baark 2007). Grounding these logics are distinctive capabilities (Kunamaneni 2019) in areas of governance structures (Rasiah et al. 2016), forecasting and planning of skilled labour (Gretchenko et al. 2018), institutional readiness (Webster and Gardner 2019), and so on. These sources offer a discourse suggesting diversity of capabilities as a source of innovative strength for institutions. Thus, context assumes an important role for institutional innovation with varying interests in institutional (Colwell and Narayanan 2010; Lindelöf 2011), country (Lee and Yoo 2008), and cultural (McCarthy et al. 2014; Piana et al. 2015) contexts. 
Yet, empirical evidence suggests these positive enabling priorities may possess negative constraining concerns contingent on circumstances. For instance, there are studies on institutional inhibitors such as organisational slack (Malen and Vaaler 2017), institutional voids (Turker and Vural 2017; Onsongo 2019), and institutional misalignments (Bunduchi et al. 2015). This contradiction motivates studies on institutional environments with focus on corporate governance (Yi et al. 2012), and professional resistance (Radaelli et al. 2017). Institutional theory also posits on isomorphic, coercive, normative, and mimetic pressures as affecting environments that enact institutional innovation with interests in links with religion (Assouad and Parboteeah 2018), and alliances (Alexander 2012). The complexity of environments within which institutions operate also elevates the importance of designs for innovation systems and new international ventures (Hargrave and Van De Ven 2006; Boudreau and Lakhani 2016).

\subsection{Economic conditions, policies, and intermediaries}

ECPI is the next priority with themes detailing management of production and consumption conditions. Financial management lies at the heart of economic imperatives for commercialisation, investment, managerial incentives, costs, profitability, and shareholding in terms of institutional innovation. These imperatives motivate research interest, particularly in relation to financial (Vermeulen et al. 2007b) and microfinance (Elle 2017) services for addressing concerns such as investment horizons (Kim et al. 2019), economic returns (Heher 2006), transaction costs (Aziz et al. 2019), and financial fraud (Yang et al. 2017). These constructs aid in examining innovation outputs (e.g., patents), composition of the firms in joint ventures, and investment objectives for incremental and radical innovation.

Economic policies are themes involving guidelines, procedures, or processes for achieving rational objectives and outcomes. Policies considered within the literature include public (Adebowale 2012; Doblinger et al. 2016; Allen et al. 2020), innovation (Liu et al. 2011; May and Schedelik 2019), community (Molnár 2004), institutional (Niosi 2010), technology (Harding 2000; George and Prabhu 2003; Vasudeva 2009), and antitrust (Hart 2001) policies. Effective management under these policies depend on legitimacy, investment efforts, risk-taking behaviour, technological stalemate, and evolutionary trajectories. Studies also identify institutional intermediaries (Watkins et al. 2015; Landoni 2017) and their economic impact on innovativeness for climate change, innovative capability for public procurement, brokering knowledge in networks, and commercialisation of technologies.

\subsection{Institutional strategies, ownership, and governance}

$I S O G$ is the management priority that steers and coordinates efforts towards enhancing innovation levels and improving institutional performance. In this context, institutional innovation scholarship proposes governing procedures and practices in concepts of governance structure (Whitley 2000; Casper and Matraves 2003), governance institution quality (Bekhet and Latif 2018), financial governance 
(Hyvärinen 2006), corporate governance (Yoshikawa et al. 2007; Yang et al. 2017), participatory governance (Forde 2020; Kalinowski 2020), and institutional arbitrage (Clausen 2014). Challenges to empower stakeholders spur increasing shifts from government to governance (Nielsen et al. 2004; Clapp et al. 2016) with goals of gaining legitimacy from transformational and executive leadership that facilitates institutional change and reform (Williams 2002; Asiedu et al. 2020). The literature also accentuates institutional strategies (Brinckmann 1998; Villavicencio et al. 2015; Smink et al. 2015), legitimacy (Hung and Whittington 2011), open innovation strategies (Kitagawa and Robertson 2011; Smink et al. 2015; Abramov et al. 2019), strategic transactions and dialogue (Wallman 2009), offshoring innovation strategies (Sartor and Beamish 2014), and growth strategies (Koh 2006). For other scholars, ownership of rights and control serves as the foundation for strategies on institutional innovativeness. Here, the interest of research lies in the mechanisms that structure institutional ownership (Cooke and Saini 2010; Yi et al. 2017), equity ownership and institutional investors (Sakaki and Jory 2019), and state ownership (Yi et al. 2017).

\subsection{Technology readiness, transfer, and support}

The next management priority is TRTS, which plays a crucial role in institutional innovation levels and economic progress for countries (Clark 2002). The suggestion is that technology readiness to fulfil the needs of institutions remains a focal point for research (Webster and Gardner 2019; Markey-Towler 2020; Mohsen et al. 2021), and motivates studies on technology co-evolution, employment relations, institutional conflicts (Hung 2000; Costa and Horn 2021), and technological institutional reform (Clark 2002). In some technology readiness studies, researchers focus on technology development (Lee 2012) and available technological capabilities (la Hiz et al. 2019) for global innovations. Authors also explore institutional readiness in the context of technological foresight for facing future challenges (Quiroga and Martin 2017). From earlier emphasis on adoption and rejection stemming from institutional bandwagon pressures, the debate in the literature somewhat shifts to diffusion trajectories of continuous self-propagating technological innovation by institutions (Matzner 1985; Abrahamson and Rosenkopf 1993; Nagamatsu et al. 2006). Examples of these technologies include big data analytics (Yau and Lau 2018), telemedicine (Oborn et al. 2021), electronic cash transfers (Zhang and Putzel 2016), the Internet of Things (Xie and Yang 2021), and smart contracts based on financial technologies (Mishchenko et al. 2021).

In furtherance of readiness, technology transfer and support tend to play crucial roles in institutions of some emerging economies and sectors with low technological intensity. Empirical evidence in some studies link technology transfer to innovation diffusion patterns (Zweifel 1995; Kwon et al. 2009; Barbosa and Faria 2011) and knowledge transfer (Mason and Wagner 1999). Other studies consider internationalisation (Kumar et al. 2013; Suzuki 2015) and innovation offshoring (Rosenbusch et al. 2019) in the context of technological barriers and institutional arbitrage strategies. Within the literature, IPR is a technology-related concept crucial to supporting 
innovation. Here, the focus is on patents as a protection entity with research examining IPR in terms of geographical indicators (Juk and Fuck 2015), rights (Malva et al. 2013; Huang et al. 2017), sources (Abereijo et al. 2009), patent behaviour (Barros 2015), and domain-spanning patent applications (Ferguson and Carnabuci 2017). Management challenges confronted within existing IPR research for institutional innovation include patenting strategies, infringements of property rights, and new SME production and knowledge recombination strategies.

\subsection{Institutional synergies, incentives, and entrepreneurship}

The final priority is ISIE that influences the pooling of complementary resources for new ventures by institutions and institutional actors. Recognising the need for synergies to deliver new solutions and systems, researchers tend to agree on the need for co-creation (Kumari et al. 2020; Sharma and Sharma 2021), co-management (Léopold et al. 2019; Casagrande et al. 2021), and co-decisions for institutional resources (Shackleton and Raunio 2003). For instance, modern innovative drugs increasingly require co-development by pharmaceutical enterprises and scientific research institutions (Wang and Huang 2020). Thus, the complementary nature of institutions (Da Silva 2019), institutional roles (Garrick et al. 2011) and institutional arrangements (Lee and Yoo 2008; Corsi and Prencipe 2019), serves as foci for some studies seeking to improve integration and accountability in institutions.

Alternate perspectives note the need to manage convergence into cross-border innovations, symbiotic relationships, and collaborative agglomeration for regions (Singh and Allen 2006; Li and Xing 2020; Knickel et al. 2021). Technically, there are also enduring institutional challenges for co-generation e.g. of heat and electricity (Chartock et al. 1985). In these contexts, synergetic innovation serves as the mission for arrangements such as industry-university-research collaboration (Xu et al. 2020), and public-private partnership (Zhang and Tan 2019; Cechin et al. 2021).

For some scholars, entrepreneurship is the cornerstone of strategies for institutional innovation. However, these authors vary in their underlying viewpoints, with interests in institutional entrepreneurs (Wang and Swanson 2007; Jensen and Fersch 2019), entrepreneur roles (Tumbas et al. 2018), entrepreneurial mind-sets (Cowden and Bendickson 2018), the influence of quality on entrepreneurship (Veiga et al. 2020), and interfaces between entrepreneurship and marketing (Laurell 2018). Irrespective of the viewpoint, the necessity- and opportunity-based nature of entrepreneurs guides researchers in positing and analysing entrepreneurship links with economic growth (Galindo-Martín et al. 2020). Closely linked to motivating entrepreneurial endeavours within institutions is the role of incentives, which literature links to the overcoming of market failures (Tang et al. 2020b) and the implementation of regulations (Costa-Font and Puig-Junoy 2007). In the literature, there are additional accounts on the importance of executive incentives (Wang and Deng 2021), producers' incentives (Desmet et al. 2020), incentive properties of incomesharing arrangements (Tyson 1979), and managerial incentives (Hyvärinen 2006; Jun and Weare 2011; Tang et al. 2020a). Yet, it is worth noting that the presence 
of conflicting incentives may ultimately undermine innovation efforts (Carney and Zheng 2009).

\section{Future research directions for institutional innovation scholarship}

Using insights from the literature, this review contributes to research by proposing a multi-level model for managing institutional innovation, as shown by Fig. 5. Premised on a background of literature arguing for induced, collective, and continuous genesis of institutional innovation, and supported by injections or 'pumps' of investments, the model advances knowledge by summarising the findings of the review in terms of key institutional determinants and management priorities. The main argument of the model is that innovation contexts shape the key determinants within institutions and that these determinants influence management priorities for institutional innovation. Our multi-level framing of priorities, determinants, and contexts, offers a set of factors that adds to the discourse concerning the need for more holistic assessments of institutional foundations, which current research elaborates in the form of deep institutional foci (Hughes et al. 2021), and co-evolution processes (Costa and Horn 2021). However, in practice, far from suggesting a panacea for managing the challenges and opportunities in institutions, the model, through the systematic insights from the literature, offers a research perspective on potential critical factors for stage-managing and enacting organisational, social, environmental, and governmental changes via contracts, internalisation, regulation, and referendums. In this section, we use insights from the review to set a research agenda that entails three potential paths for future research.

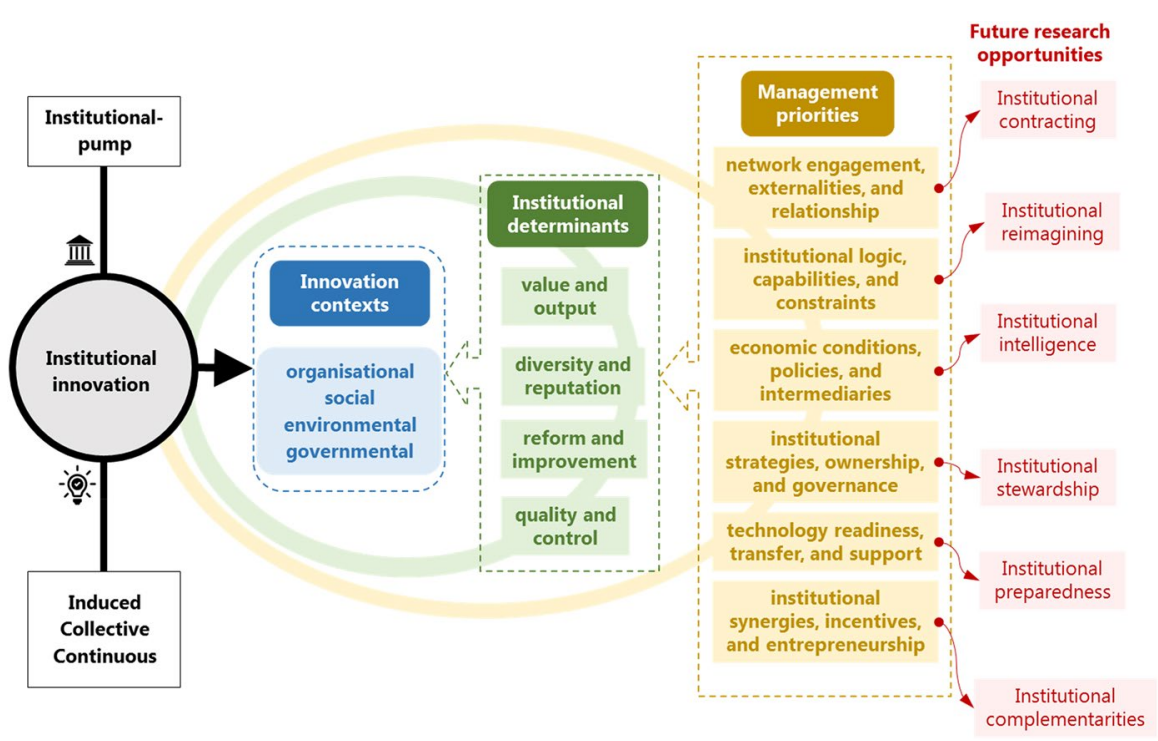

Fig. 5 Multi-level management model of Institutional Innovation 
To begin with, a critique of the theoretical and methodological space in literature provides the first path for future studies. In this context, in current studies and as shown in Fig. 4b, the balance of the theoretical base appears tilted towards institution-oriented theories, particularly institutional theory treated in 95 studies. This raises the prospect for more innovation studies to offset this imbalance by testing existing innovation theories (e.g., diffusion of innovation) in different contexts, examining theories with limited coverage (e.g., the Bass model) in an institutional milieu, and proposing new theories. Current determinants analysed from the review mainly consider the institutional aspects for innovation, as shown by Sect. 4. Thus, examinations driven by more framings of innovation could generate new insights on potential innovation-oriented determinants such as creativity, mindfulness, foresight, innovative climate, etc. Methodologically, researchers seem to favour case studies, surveys, essays, and econometric analysis. To a lesser extent, the review indicates interest in the use of decision analysis, meta-analysis, action research, and field experiments. Thus, there is a need for further investigations of the conceptual space for institution innovation using lesser-applied methods along with studies applying novel methods such ethnography, online research, meta-synthesis, phenomenography, and grounded theory. Existing management priorities in the literature mainly reflect macro- and meso-level considerations of institutional innovation, particularly in the context of regional, national, sectoral, and organisational concerns. Accordingly, there is a need for further studies of micro-level considerations, i.e., individual factors that enable or inhibit institutional innovation. For instance, grounded theory or ethnography-based studies could explore and theorise on personas, personalities, and motivations of institutional actors that play major roles in inducing, coordinating collective action, or championing continuous change. Similarly, online research or phenomenography could underpin explorations on the role and factors of technology (e.g., social media) use by institutional actors in relation to embedded and established routines for innovation stages (e.g., ideation) in institutions.

In line with current studies, this review challenges researchers to explore policy void in industrialised and social contexts (Mehmood 2016; Onsongo 2019) and investigate the role of institutional mediators and factors (Laurell 2018; Tomizawa et al. 2020) in relation to institutional adaptation for regional innovations. There are also challenges to detangle institutional variations concerning how formal and informal institutions shape innovation types, practices, and processes (Chadee and Roxas 2013; Filiou and Golesorkhi 2016; Huang et al. 2017). Further challenges exist regarding the multi-faceted role of institutional environments that positively endorse and enable, or negatively inhibit and inactivate institutional innovations (Whitley 2000; Wang and Swanson 2007; Mueller et al. 2013; Wu et al. 2016; Fischer and Tello-Gamarra 2017; Nite and Washington 2017; Kadriu et al. 2019; Wu and Park 2019).

Derived from reflections on the management priorities of the previous section, the third path for future studies extends the synthesis from the review for topical viewpoints that strategically advance the field of institutional innovation. In the next subsections, we present these paths, detail current related efforts, and elaborate on some specific research challenges for management scholarship concerning institutional innovation. 


\subsection{Institutional contracting}

The first challenge involves studies of institutional contracting (mainly from reflections on NEER) that examine the process of engagement, building relationships, and bargaining with contractors for formulating and implementing contracts. Accordingly, studies of institutional contracting advance NEER management, and in the proposed model of Fig. 5, NEER management maintains social exchanges within institutions in accordance with contingency, agency, and transaction cost theories. With increasing global trends towards privatisation, urbanisation, internationalisation, and digitalisation, the indications are that contracts remain crucial for maintaining transdisciplinary and interdisciplinary engagement within institutions. In current literature, new forms of contracts serve as the focus of innovation by agricultural institutions for contract farming (Escobal 2000; Bhanot et al. 2021) and supplier contracts with research institutions (Nordberg et al. 2003). There are also discussions on the value of smart contracts developed by financial institutions (Mishchenko et al. 2021). Although contracts are well-established as a form of institutional innovation (Polopolus 1969), studies on the nature of contracting remains limited. Therefore, we urge for research exploring the nature of contracting that enables institutional innovation and critical success factors of this contracting process. With evidence suggesting that contract enforcement challenges may cause the emergence of new institutions (Dimitri 2002), future research could theorise on and empirically investigate enforcement mechanisms for sourcing and contracting institutional innovation. Research also suggests that inadequate contracting processes account for several regulatory failures (Costa-Font and Puig-Junoy 2007), challenging future studies to expand on normative frameworks for contracting within institutions.

\subsection{Institutional reimagining}

The next challenge relates to research on institutional reimagining (from reflections on $I L C C)$ to offer a critical view that complements existing analytical insights from studying opportunities and challenges of induced, continuous, and collective institutional innovation. Hence, research on institutional reimagining furthers $I L C C$ management, and in the proposed model of Fig. 5, ILCC management involves coordinating capabilities under institutional constraints that reflect resource-based, dynamic capabilities, absorptive capacities, and institutionalpump framings. This coordination requires awareness and support for the construction of institutional narratives (Schofield 2000) and consciousness capabilities of new global imaginaries (Hughes et al. 2021). In furtherance of these efforts, we propose that researchers assess institutions critically on an on-going basis to promote transdisciplinary efforts that avert institutional stagnation when confronting societal challenges. With insights from the literature and in line with institutional theory, this review highlights the need for critical reflections on the measures and pressures that shape innovation success. Multi-level analysis could aid in uncovering the micro, meso, and macro levels that are critical to promoting 
success and averting collapse of institutions. Critiques could also compare upand-up and divide-and-conquer strategic plans to highlight instances of wasteful tax-and-spend policies.

Recognising the threat of institutional obsolescence discussed in early research (Polopolus 1969; Shaffer 1969), we also propose future research on the collapse of institutions, in the context of failed institutional logics for innovation to capture reasons, detail lessons learnt, review existing policy toolboxes, and reimagine failed institutions. For instance, the collapse of financial institutions in 2008 and economic collapse due to the COVID-19 are instances of institutional collapse with negative global consequences. Thus, this line of research could strive to analyse innovation determinants for recovery or reconstruction of institutions. Questions guiding such research efforts include 'how can governments innovatively reconstruct collapsed institutions?' and 'what structural and behavioural attributes contribute to the collapse of institutions?' Future research could also use insights from lessons learnt to provide innovative forecasting tools to avert institutional collapse.

\subsection{Institutional intelligence}

Another challenge for studies involves analysing institutional intelligence (from reflections on ECPI). Research concerning institutional intelligence encompasses assessments of the data analytic capacities (e.g. big data analytics (Yau and Lau 2018)) that harness the potentials of institutional information, and the intelligent intermediaries (Chen et al. 2015) that facilitate innovation, particularly in relation to recruiting, retaining, and developing intelligent employees. Consequently, institutional intelligence research advances ECPI management, which represents a fundamental component of the proposed multi-level management model, as represented by Fig. 5, and determines economic benefits from institutional innovation, in line with economic theory. Although, this review incorporates studies on the need to attract top talent for innovative research in higher education (Dahm et al. 2021) and innovation 'offshoring' to emerging countries (Desai 2009), this line of inquiry remains limited in the context of institutional innovation research. Accordingly, we challenge academia to explore the range of data analytics for institutional innovation further, along with concepts such as institutional optimisation, innovative talent capacity building, institutional intelligence, and talent management strategies. Studies may also consider intelligence and talent management in relation to roles of actors in constructs like the quadruple helix, and control mechanisms, e.g., managerial incentives and corporate governance. Since intelligence and talent are human capital constructs, there are questions concerning effectiveness of top-down and bottom-up strategies within institutions. Some questions include 'how effective is upper management in retaining talent for innovation?' and 'what is nature of team involvement in selecting and sourcing analytic capabilities for institutional innovation?'. 


\subsection{Institutional stewardship}

For management researchers, there are future opportunities to examine institutional stewardship (mainly from reflections on $I S O G$ ). With emphasis on responsibility and accountability, stewardship progresses $I S O G$ management and embodies the control and sense of duty demanded by on-going shifts from government to governance (Clapp et al. 2016) for boosting participation and empowerment for institutional innovation. ISOG management, in the proposed model of Fig. 5, involves governance that promotes pro-innovation institutions and is in line with agency and actor network theories. In this review, studies offer insights on related challenges for participatory governance (Forde 2020) and leadership (Williams 2002; Asiedu et al. 2020) that trend towards a sense of duty by institutional actors. Despite these research efforts, the literature provides limited bottom-up insights on the potential role of stewards in promoting institutional innovation and innovation contexts, i.e., organisational, environmental, social, and governmental. Future research could study specific roles of institutional stewards for radial and incremental innovations. Although, empirical evidence suggests links between stewardship behaviour and the success of innovation (Domínguez-Escrig et al. 2019), there are opportunities for studies to test this relationship in normative and cognitive institutional contexts. Future research may also view challenges of institutional stewardship in isolation or in conjunction with existing inadequacies due to institutional pressures, voids, and barriers.

\subsection{Institutional preparedness}

Another potential research direction involves studies of institutional preparedness (mainly from reflections on TRTS), in the context of more frequently occurring macroeconomic shocks and technological transformations in society that threaten the legitimacy of institutions. Traditionally a focus of studies on agents of change (Ebegbulem 1974), research on readiness in an institutional context increasingly focuses on preparedness that supports trajectories of self-propagating technologies (Nagamatsu et al. 2006). Institutional preparedness, in this context, refers to how institutions are equipped in terms of capabilities and capacities to respond to new challenges and opportunities. The proposed multi-level model of Fig. 5 advances TRTS management for technology readiness as an element of institutional preparedness, with conceptual underpinnings from contingency and diffusion theory. Yet, there remain challenges to understand future innovation contexts and preparedness by institutions for praxis and crisis situations, proactively and reactively. For instance, recent dengue, Zika, and coronavirus outbreaks have challenged the role of traditional innovation-driven approaches, which focus on opportunity, and shifted the attention to ingenuity to cope with adversity. In addition, there are challenges to examine the infusion and routinisation (beyond the adoption and diffusion foci of current research (e.g., Genus 2012; Oborn et al. 2021)) of technologies emerging due to the Fourth Industrial Revolution (e.g., synthetic data, biotechnology, and $3 \mathrm{D}$ printing). Thus, future studies may consider challenges such as institutional 
roadmaps with foresights for emerging technologies and institutional skilling needs. Other investigations could consider preparedness constructs for innovative institutions and crisis-driven innovation contexts for institutions.

\subsection{Institutional complementarities}

The final challenge involves research on institutional complementarities (mainly from reflections on ISIE) for examining the ability of institutions to supplement other institutions in the quest for innovation, or the degree to which institutional arrangements, roles, factors, and innovation emphasise or improve each other. Just as innovation complements other explanations of economic growth (e.g., geography, and international trade), opportunities exist to investigate the complementarities for institutional innovation. For this reason, studies of institutional complementarities further ISIE management, and in the proposed model of Fig. 5, ISIE management ensures integration and incentivisation within institutions in accordance with resource-based and dynamic capabilities views. Discussions in the literature on compatibility and substitutability (Corsi and Prencipe 2019; Da Silva 2019) reinforce the role of strategies for complementarities in sustaining synergies and incentivising entrepreneurial ventures within institutions. Yet, questions remain on the scope, range, and forms of complementarities that facilitate institutional innovation. For instance, the prospect of 'creative complementarities' that supply creativitydriven resources and know-how (Durugbo et al. 2020a), suggests possibilities for implementation, adoption, and continuance forms of complementarities that incentivise induced, continuous, and collective institutional innovation. Lines of inquiry could examine the nature of complementarities that (dis)incentivise entrepreneurial endeavours within institutions. Such focus is needed because the literature in this review suggests that conflicting incentives within institutions inevitably deter innovative activities (Carney and Zheng 2009). Further studies could also examine institutional complementariness for innovation in the context of determinants such as quality, productivity, diversity, and so on. In addition, complementary viewpoints may consider and explore the role of complementarities in addressing challenges of inequality, sustainability, security etc.

\section{Conclusions}

In the words of Pablo Picasso, "learn the rules like a pro, so you can break them like an artist". This saying underscores the need for ingenuity and innovation by institutions, as the rules of societies or of organisations to deliver value for a range of stakeholders such as citizens, governmental agencies, customers, and industry. Additionally, innovation in an institutional milieu faces pressures, voids, and barriers that force institutions to shift from scalable efficiency to scalable learning in efforts to expand management strategy and policy horizons. Consequently, transdisciplinary insights on the key determinants and management priorities of institutional innovation are critical to cope with the inherent dynamic 
nature and tension between institutional persistence and innovative practices. These determinants and priorities aid institutions deliver breakthrough processes and outcomes that require review on an on-going basis to update scholarship and practice. With this in mind, this review confronts the following research question: "What are the main determinants and management priorities of institutional innovation in the literature?" $(R Q)$.

Driven by a systematic approach that seeks to address $R Q$, this review summarises its findings in a multi-level management model for institutional innovation in terms of innovation contexts, institutional determinants, and management priorities. Grounded on organisational, social, environmental, and governmental contexts for innovation, the review identified four key determinants concerning (i) innovation quality and control; (ii) institutional diversity and reputation; (iii) innovation value and output; and (iv) institutional reform and improvement. Similarly, the review captured six management priorities concerning network engagement, externalities, and relationships; institutional logic, capabilities, and constraints; economic conditions, policies, and intermediaries; institutional strategies, ownership, and governance; and technology readiness, transfer, and support; and institutional synergies, incentives, and entrepreneurship.

There are two main limitations of this review. First, the review focus is limited to capturing the main determinants and management priorities of institutional innovation. In this context, there is a need for additional insights on aspects such as innovation activities, the behaviour of institutional actors, and institutional arrangements. Second, the review approach is restricted to a systematic methodology that applies thematic analysis. Hence, there are prospects for deeper insights based on other review methodologies such as meta-analyses and metasyntheses that offer more focused and extensive knowledge on constructs, dependencies, and links between variables within qualitative and quantitative studies of institutional innovation. Further analysis of co-citations could offer knowledge on the nature of citation dynamics and potential connections between publications.

Guided by insights from the findings on management priorities, the review identifies six strategic areas for future management research on institutional contracting, reimagining, intelligence, stewardship, preparedness, and complementarities. In summary, the review anticipates that the necessities and niceties of these proposed areas will aid in strengthening existing knowledge on institutional innovation and in uncovering new and exciting institutional phenomena, prospects, and potentials as managers set ground rules on contexts for innovation and run the rule over determinants within institutions.

Funding The authors declare that no funds, grants, or other support were received during the preparation of this manuscript.

\section{Declarations}

Conflict of interest The authors have no relevant financial or non-financial interests to disclose. 


\section{References}

Abereijo IO, Adegbite SA, Ilori MO et al (2009) Technological innovation sources and institutional supports for manufacturing small and medium enterprises in Nigeria. J Technol Manag Innov 4:82-89. https://doi.org/10.4067/S0718-27242009000200007

Abrahamson E, Rosenkopf L (1993) Institutional and competitive bandwagons: Using mathematical modeling as a tool to explore innovation diffusion. Acad Manag Rev 18:487. https://doi.org/10. $2307 / 258906$

Abramov RA, Sokolov MS, Derevianko SV (2019) Institutional framework for entrepreneurship of regional innovation systems of the union state. Acad Entrep J 25:1-6

Adebowale BOA (2012) Innovation policies institutions and performance: Why Malaysia overtook Nigeria in the oil palm industry. Int J Technol Learn Innov Dev 5:126-157. https://doi.org/10.1504/ IJTLID.2012.044880

Adomssent M, Michelsen G (2006) German Academia heading for sustainability? Reflections on policy and practice in teaching, research and institutional innovations. Environ Educ Res 12:85-99. https://doi.org/10.1080/13504620500527758

Afshari-Mofrad M, Ghazinoory S, Nasri S (2021) Measuring the efficiency, effectiveness and changeability of institutions for improving national innovation system. Asian J Technol Innov 29:233-257. https://doi.org/10.1080/19761597.2020.1797517

Agarwal B (2020) A tale of two experiments: institutional innovations in women's group farming in India. Can J Dev Stud 41:169-192. https://doi.org/10.1080/02255189.2020.1779673

Aguilera-Caracuel J, Ortiz-de-Mandojana N (2013) Green innovation and financial performance: an institutional approach. Organ Environ 26:365-385. https://doi.org/10.1177/1086026613507931

Alamad S, Hidayah NN, Lowe A (2021) A shared boundary object: financial innovation and engineering in Islamic financial institutions. Br Account Rev. https://doi.org/10.1016/j.bar.2020.100958

Albertini S, Muzzi C (2016) Institutional entrepreneurship and organizational innovation: The start-up of a divergent new venture at the periphery of a mature field. Int J Entrep Innov 17:110-119. https:// doi.org/10.1177/1465750316648578

AlEssa HS, Durugbo CM (2021) Systematic review of innovative work behavior concepts and contributions. Manag Rev Q. https://doi.org/10.1007/s11301-021-00224-X

Alexander EA (2012) The effects of legal, normative, and cultural-cognitive institutions on innovation in technology alliances. Manag Int Rev 52:791-815. https://doi.org/10.1007/s11575-011-0123-y

Allen DWE, Berg C, Markey-Towler B et al (2020) Blockchain and the evolution of institutional technologies: Implications for innovation policy. Res Policy. https://doi.org/10.1016/j.respol.2019.103865

Ananthram S, Chan C (2021) Institutions and frugal innovation: the case of Jugaad. Asia Pacific J Manag 38:1031-1060. https://doi.org/10.1007/s10490-019-09700-1

Andersen J, Bilfeldt A (2017) Transforming welfare institutions through social innovation and action research in Denmark. Int J Action Res 13:201-220. https://doi.org/10.3224/ijar.v13i3.02

Andrew D (2012) Institutional policy innovation in aviation. J Air Transp Manag 21:36-39. https://doi. org/10.1016/j.jairtraman.2011.12.015

Antonova NE, Lomakina NV (2020) Institutional innovations for the development of the east of Russia: Effects of implementation in the resource region. J Sib Fed Univ - Humanit Soc Sci 13:442-452. https://doi.org/10.17516/1997-1370-0580

Aragon-Correa JA, la Hiz DI (2016) The influence of technology differences on corporate environmental patents: a resource-based versus an institutional view of green innovations. Bus Strateg Environ 25:421-434. https://doi.org/10.1002/bse.1885

Arranz N, Arguello NL, de Arroyabe JC (2021) How do internal, market and institutional factors affect the development of eco-innovation in firms? J Clean Prod. https://doi.org/10.1016/j.jclepro.2021. 126692

Arribas JMG (2020) Centers of vocational excellence and innovation (CoVes): a new era for vocational education and training (VET) institutions? Acad 2020:58-84

Arun TM, Joseph RP, Ul Akram M (2020) Entrepreneur's gender and firm innovation breadth: an institution-based view of SMEs in an emerging market context. Int J Innov Manag 24:2050068. https:// doi.org/10.1142/S1363919620500681

Asheim BT, Coenen L (2006) Contextualising regional innovation systems in a globalising learning economy: on knowledge bases and institutional frameworks. J Technol Transf 31:163-173. https:// doi.org/10.1007/s10961-005-5028-0 
Asiedu MA, Anyigba H, Ofori KS et al (2020) Factors influencing innovation performance in higher education institutions. Learn Organ 27:365-378. https://doi.org/10.1108/TLO-12-2018-0205

Assouad A, Parboteeah KP (2018) Religion and innovation. A country institutional approach. J Manag Spiritual Relig 15:20-37. https://doi.org/10.1080/14766086.2017.1378589

Audretsch DB, Seitz N, Rouch KM (2018) Tolerance and innovation: the role of institutional and social trust. Eurasian Bus Rev 8:71-92. https://doi.org/10.1007/s40821-017-0086-4

Azadegan A, Napshin S, Oke A (2013) The influence of R\&D partnerships on innovation in manufacturing firms: The moderating role of institutional attachment. Int J Oper Prod Manag 33:248-274. https://doi.org/10.1108/01443571311300755

Aziz MA, Din BH, Abdulsomad K (2019) Transaction costs of the zakat institution: an open innovation approach. Institutions Econ 11:43-71

Baark E (2007) Knowledge and innovation in China: Historical legacies and emerging institutions. Asia Pacific Bus Rev 13:337-356. https://doi.org/10.1080/13602380701291917

Bahlmann J, Spiller A (2009) The effect of institutional innovations on food chain governance: a case study on the shifting role of the German QS system from certification to supply chain coordination. J Chain Netw Sci 9:89-103. https://doi.org/10.3920/JCNS2009.x173

Baker R (1989) Institutional innovation, development and environmental management: An 'administrative trap' revisited. Part II Public Adm Dev 9:29-47. https://doi.org/10.1002/pad.4230090206

Bakir C, Gunduz KA (2017) When, why and how institutional change takes place: a systematic review and a future research agenda on the importance of policy entrepreneurship in macroeconomic bureaucracies. Policy Soc 36:479-503. https://doi.org/10.1080/14494035.2017.1369676

Balthasar A, Bättig C, Thierstein A, Wilhelm B (2000) "Developers": key actors of the innovation process. Types of developers and their contacts to institutions involved in research and development, continuing education and training, and the transfer of technology. Technovation 20:523-538. https://doi.org/10.1016/S0166-4972(99)00180-7

Barasa L, Knoben J, Vermeulen P et al (2017) Institutions, resources and innovation in East Africa: a firm level approach. Res Policy 46:280-291. https://doi.org/10.1016/j.respol.2016.11.008

Barbosa N, Faria AP (2011) Innovation across Europe: how important are institutional differences? Res Policy 40:1157-1169. https://doi.org/10.1016/j.respol.2011.05.017

Barros HM (2015) Exploring the use of patents in a weak institutional environment: The effects of innovation partnerships, firm ownership, and new management practices. Technovation 45-46:63-77. https://doi.org/10.1016/j.technovation.2015.05.003

Batukova LR, Bezrukikh DV, Senashov SI et al (2019) Modernization and innovation: economic and institutional role. Espacios 40:1-16

Bekhet HA, Latif NWA (2018) The impact of technological innovation and governance institution quality on Malaysia's sustainable growth: Evidence from a dynamic relationship. Technol Soc 54:27-40. https://doi.org/10.1016/j.techsoc.2018.01.014

Bello DC, Lohtia R, Sangtani V (2004) An institutional analysis of supply chain innovations in global marketing channels. Ind Mark Manag 33:57-64. https://doi.org/10.1016/j.indmarman.2003.08.011

Bennett DL, Nikolaev B (2020) Individualism, pro-market institutions, and national innovation. Small Bus Econ. https://doi.org/10.1007/s11187-020-00396-y

Bentzen E, Freij A, Varnes CJ (2021) The role of flexibility and complexity in response to regulatory change: a case study of innovation in a major Danish financial institution. Int J Entrep Innov. https://doi.org/10.1177/1465750320987929

Berraies S, Achour M, Chaher M (2015) Focusing the mediating role of knowledge management practices: How does institutional and interpersonal trust support exploitative and exploratory innovation? J Appl Bus Res 31:1479-1492. https://doi.org/10.19030/jabr.v31i4.9331

Berrone P, Fosfuri A, Gelabert L, Gomez-Mejia LR (2013) Necessity as the mother of "green" inventions: Institutional pressures and environmental innovations. Strateg Manag J 34:891-909. https:// doi.org/10.1002/smj.2041

Beunen R, Kole S (2021) Institutional innovation in conservation law: experiences from the implementation of the birds and habitats directives in the Netherlands. Land Use Policy. https://doi.org/10. 1016/j.landusepol.2021.105566

Bhanot D, Kathuria V, Das D (2021) Can institutional innovations in agri-marketing channels alleviate distress selling? Evidence from India World Dev. https://doi.org/10.1016/j.worlddev.2020.105202

Bierut BK, Dybka P (2021) Increase versus transformation of exports through technological and institutional innovation: evidence from Bayesian model averaging. Econ Model. https://doi.org/10.1016/j. econmod.2021.105501 
Biggs S (2008) Learning from the positive to reduce rural poverty and increase social justice: Institutional innovations in agricultural and natural resources research and development. Exp Agric 44:37-60. https://doi.org/10.1017/S0014479707005959

Bin A, Gianoni C, Mendes PJV et al (2013) Organization of research and innovation: a comparative study of public agricultural research institutions. J Technol Manag Innov 8:209-218. https://doi.org/10. 4067/s0718-27242013000300048

Biurrun A (2020) New evidence toward solving the puzzle of innovation and inequality. The role of institutions. Econ Innov New Technol. https://doi.org/10.1080/10438599.2020.1853659

Bjornlund H, van Rooyen A, Pittock J et al (2020) Institutional innovation and smart water management technologies in small-scale irrigation schemes in southern Africa. Water Int 45:621-650. https:// doi.org/10.1080/02508060.2020.1804715

Blake JIR, Boyd SW, Phillips HJ et al (2021) A celebration of academic and industry collaboration: the royal national lifeboat institution and maritime engineering innovation. Proc Inst Mech Eng Part M J Eng Marit Environ 235:844-853. https://doi.org/10.1177/1475090220937901

Blättel-Mink B, Kastenholz H (2005) Transdisciplinarity in sustainability research: diffusion conditions of an institutional innovation. Int J Sustain Dev World Ecol 12:1-12. https://doi.org/10.1080/13504 500509469613

Boisvert V, Méral P, Froger G (2013) Market-based instruments for ecosystem services: institutional innovation or renovation? Soc Nat Resour 26:1122-1136. https://doi.org/10.1080/08941920.2013. 820815

Boroujerdi SS, Hasani K, Delshab V (2020) Investigating the influence of knowledge management on organizational innovation in higher educational institutions. Kybernetes 49:442-459. https://doi. org/10.1108/K-09-2018-0492

Boudreau KJ, Lakhani KR (2016) Innovation experiments: researching technical advance, knowledge production, and the design of supporting institutions. Innov Policy Econ 16:135-167. https://doi. org/10.1086/684988

Boudreaux CJ (2017) Institutional quality and innovation: some cross-country evidence. J Entrep Public Policy 6:26-40. https://doi.org/10.1108/JEPP-04-2016-0015

Boulanger P-P, Gagnon C (2018) Financial innovation and institutional voices in the Canadian press: a look at the roaring 2000s. Int J Bus Commun 55:383-405. https://doi.org/10.1177/2329488417 747596

Brinckmann H (1998) Infrastructure and tools for successful institutional innovation. Tert Educ Manag 4:48-58. https://doi.org/10.1080/13583883.1998.9966945

Buchheim L, Krieger A, Arndt S (2020) Innovation types in public sector organizations: a systematic review of the literature. Manag Rev Q 70:509-533. https://doi.org/10.1007/s11301-019-00174-5

Buck RC, Rath RA (1970) Planning as institutional innovation in the smaller city. J Am Plan Assoc 36:59-64. https://doi.org/10.1080/01944367008977281

Bunda NR, Spatariu EC, Popovici N (2014) The institutional framework and innovation levels in EU countries. Transform Bus Econ 13:584-601

Bunduchi R, Smart A, Charles K et al (2015) When innovation fails: an institutional perspective of the (non)adoption of boundary spanning IT innovation. Inf Manag 52:563-576. https://doi.org/10. 1016/j.im.2015.04.001

Buszard D, Kolb J (2011) Institutional innovation to deliver post-secondary education for sustainability. Sustain J Rec 4:80-84. https://doi.org/10.1089/SUS.2011.9706

Buttoud G, Kouplevatskaya-Buttoud I, Slee B, Weiss G (2011) Barriers to institutional learning and innovations in the forest sector in Europe: Markets, policies and stakeholders. For Policy Econ 13:124131. https://doi.org/10.1016/j.forpol.2010.05.006

Carlsson B (1997) Technological systems and industrial dynamics. Kluwer Academic Publishers, Massachusetts

Carney RW, Zheng LY (2009) Institutional (dis)incentives to innovate: an explanation for Singapore's innovation gap. J East Asian Stud 9:291-319. https://doi.org/10.1017/S1598240800003015

Casagrande A, Salvatore R, Rover OJ et al (2021) Artisanal mollusc fisheries co-management in Brazil and Italy: Institutional innovations to address environmental crisis. J Environ Manage. https://doi. org/10.1016/j.jenvman.2021.112671

Casper S, Matraves C (2003) Institutional frameworks and innovation in the German and UK pharmaceutical industry. Res Policy 32:1865-1879. https://doi.org/10.1016/S0048-7333(03)00082-9 
Cechin A, da Silva AV, Amand L (2021) Exploring the synergy between community supported agriculture and agroforestry: institutional innovation from smallholders in a brazilian rural settlement. J Rural Stud 81:246-258. https://doi.org/10.1016/j.jrurstud.2020.10.031

Cestino J, Berndt A (2017) Institutional limits to service dominant logic and servitisation in innovation efforts in newspapers. J Media Bus Stud 14:188-216. https://doi.org/10.1080/16522354. 2018.1445163

Chadee D, Roxas B (2013) Institutional environment, innovation capacity and firm performance in Russia. Crit Perspect Int Bus 9:19-39. https://doi.org/10.1108/17422041311299923

Chartock MA, Devine MD, Gunn EM (1985) Institutional innovation for cogeneration. Rev Policy Res 5:89-95. https://doi.org/10.1111/j.1541-1338.1985.tb00012.x

Chebrolu SP, Dutta D (2021) Managing sustainable transitions: Institutional innovations from india. Sustain. https://doi.org/10.3390/su13116076

Chen G (2018) Social sharing institution of SMEs' technology innovation risk. IPPTA Q J Indian Pulp Pap Tech Assoc 30:323-330

Chen S-H, Egbetokun AA, Chen D-K (2015) Brokering knowledge in networks: Institutional intermediaries in the Taiwanese biopharmaceutical innovation system. Int J Technol Manag 69:189_ 209. https://doi.org/10.1504/IJTM.2015.072978

Chen W, Han C, Wang L et al (2021) Recognition of entrepreneur's social ties and firm innovation in emerging markets: explanation from the industrial institutional environment and survival pressure. Asia Pacific J Manag 38:491-518. https://doi.org/10.1007/s10490-019-09680-2

Chen X, Yi N, Zhang L, Li D (2018) Does institutional pressure foster corporate green innovation? Evidence from China's top 100 companies. J Clean Prod 188:304-311. https://doi.org/10. 1016/j.jclepro.2018.03.257

Chhetri N, Chaudhary P, Tiwari PR, Yadaw RB (2012) Institutional and technological innovation: understanding agricultural adaptation to climate change in Nepal. Appl Geogr 33:142-150. https://doi.org/10.1016/j.apgeog.2011.10.006

Chien S-S (2007) Institutional innovations, asymmetric decentralization, and local economic development: a case study of Kunshan, in Post-Mao China. Environ Plan C Gov Policy 25:269-290. https://doi.org/10.1068/c0558

Chittoor R, Aulakh PS, Ray S (2015) Accumulative and assimilative learning, institutional infrastructure, and innovation orientation of developing economy firms. Glob Strateg J 5:133-153. https://doi.org/10.1002/gsj.1093

Chu Z, Xu J, Lai F, Collins BJ (2018) Institutional theory and environmental pressures: the moderating effect of market uncertainty on innovation and firm performance. IEEE Trans Eng Manag 65:392-403. https://doi.org/10.1109/TEM.2018.2794453

Cinar R, Benneworth P (2021) Why do universities have little systemic impact with social innovation? An institutional logics perspective. Growth Change 52:751-769. https://doi.org/10.1111/grow. 12367

Clapp A, Hayter R, Affolderbach J, Guzman L (2016) Institutional thickening and innovation: reflections on the remapping of the Great Bear Rainforest. Trans Inst Br Geogr 41:244-257. https:// doi.org/10.1111/tran.12119

Clark GL, Monk AHB (2016) Ambiguity, contract, and innovation in financial institutions. Compet Chang 20:187-203. https://doi.org/10.1177/1024529416635930

Clark N (2002) Innovation systems, institutional change and the new knowledge market: Implications for third world agricultural development. Econ Innov New Technol 11:353-368. https://doi.org/ $10.1080 / 10438590200000004$

Clark N, Clay E (1987) The dryland research project at indore (1974-1980)—an institutional innovation in rural technology transfer. J Rural Stud 3:159-173. https://doi.org/10.1016/07430167(87)90031-3

Clausen TH (2014) The role of institutional arbitrage in the search for product innovation: firm level evidence from Norway. Ind Mark Manag 43:392-399. https://doi.org/10.1016/j.indmarman. 2013.12.007

Colwell K, Narayanan VK (2010) Foresight in economic development policy: shaping the institutional context for entrepreneurial innovation. Futures 42:295-303. https://doi.org/10.1016/j.futures. 2009.11.015

Considine M, Lewis JM (2007) Innovation and innovators inside government: From institutions to networks. Governance 20:581-607. https://doi.org/10.1111/j.1468-0491.2007.00373.x 
Cooke FL, Saini DS (2010) (How) Does the HR strategy support an innovation oriented business strategy? An investigation of institutional context and organizational practices in Indian firms. Hum Resour Manage 49:377-400. https://doi.org/10.1002/hrm.20356

Cooke P, Uranga MG, Etxebarria G (1997) Regional innovation systems: Institutional and organisational dimensions. Res Policy 26:475-491. https://doi.org/10.1016/S0048-7333(97)00025-5

Coriat B, Weinstein O (2002) Organizations, firms and institutions in the generation of innovation. Res Policy 31:273-290. https://doi.org/10.1016/S0048-7333(01)00141-X

Corsi C, Prencipe A (2019) High-tech entrepreneurial firms' innovation in different institutional settings. Do venture capital and private equity have complementary or substitute effects? Ind Innov 26:1023-1074. https://doi.org/10.1080/13662716.2018.1561358

Corsini F, Rizzi F, Frey M (2018) Institutional legitimacy of non-profit innovation facilitators: strategic postures in regulated environments. Technol Soc 53:69-78. https://doi.org/10.1016/j.techsoc.2018. 01.002

Costa-Font J, Puig-Junoy J (2007) Institutional change, innovation and regulation failure: evidence from the Spanish drug market. Policy Polit 35:701-718. https://doi.org/10.1332/030557307782452994

Costa RMD, Horn CH (2021) The co-evolution of technology and employment relations: Institutions, innovation and change. Struct Chang Econ Dyn 58:313-324. https://doi.org/10.1016/j.strueco. 2021.06.003

Cowden BJ, Bendickson JS (2018) Impacts of regulatory focus and institutions on innovation. Manag Decis 56:939-954. https://doi.org/10.1108/MD-11-2016-0826

d'Agostino G, Scarlato M (2019) Knowledge externalities, innovation and growth in European countries: the role of institutions. Econ Innov New Technol 28:82-99. https://doi.org/10.1080/10438599. 2018.1429536

Da Silva MAPM (2019) Open innovation and IPRs: Mutually incompatible or complementary institutions? J Innov Knowl 4:248-252. https://doi.org/10.1016/j.jik.2018.03.010

Dahm R, Byrne JR, Rogers D, Wride MA (2021) How research institutions can foster innovation. BioEssays. https://doi.org/10.1002/bies.202100107

Daly S (2008) Institutional innovation in philanthropy: Community foundations in the UK. Voluntas 19:219-241. https://doi.org/10.1007/s11266-008-9067-7

Darvas P (1997) Institutional innovations in higher education in central Europe agenda for research and co-operation. Tert Educ Manag 3:119-132. https://doi.org/10.1080/13583883.1997.9966915

Davis L, North D (1970) Institutional change and American economic growth: a first step towards a theory of institutional innovation. J Econ Hist 30:131-149. https://doi.org/10.1017/S00220507000786 33

De Jong G, Woolthuis RK (2008) The institutional arrangements of innovation: antecedents and performance effects of trust in high-tech alliances. Ind Innov 15:45-67. https://doi.org/10.1080/13662 710701858520

de la Mothe J (2004) The institutional governance of technology, society, and innovation. Technol Soc 26:523-536. https://doi.org/10.1016/j.techsoc.2004.01.009

De Laurentis C (2006) Digital knowledge exploitation: ICT, memory institutions and innovation from cultural assets. J Technol Transf 31:77-89. https://doi.org/10.1007/s10961-005-5014-6

de Leeuw T, Gössling T (2016) Theorizing change revisited: An amended process model of institutional innovations and changes in institutional fields. J Clean Prod 135:435-448. https://doi.org/10. 1016/j.jclepro.2016.06.119

De Mothe JL (1995) Research instrumentation and institutional innovation in Canada. Technol Anal Strateg Manag 7:63-77. https://doi.org/10.1080/09537329508524195

de Zubielqui GC, Jones J, Seet P-S, Lindsay N (2015) Knowledge transfer between actors in the innovation system: A study of higher education institutions (HEIS) and SMES. J Bus Ind Mark 30:436458. https://doi.org/10.1108/JBIM-07-2013-0152

Desai DA (2009) Innovations in emerging countries: an institutional approach. Int J Technol Glob 4:350. https://doi.org/10.1504/IJTG.2009.032736

Desmet K, Greif A, Parente SL (2020) Spatial competition, innovation and institutions: the Industrial Revolution and the Great Divergence. J Econ Growth. https://doi.org/10.1007/s10887-019-09173-3

Della MA, Lissoni F, Llerena P (2013) Institutional change and academic patenting: French universities and the Innovation Act of 1999. J Evol Econ 23:211-239. https://doi.org/10.1007/ s00191-011-0243-3 
Didenko NI, Romashkina GF, Skripnuk DF, Kulik SV (2020) Dynamics of trust in institutions, the legitimacy of the social order, and social open innovation. J Open Innov Technol Mark Complex 6:1-24. https://doi.org/10.3390/joitmc6040111

Dimitri C (2002) Contract evolution and institutional innovation: Marketing pacific-grown apples from 1890 to 1930 . J Econ Hist 62:189-212. https://doi.org/10.1017/S002205070204408X

Dimitri C, Jaenicke EC, Effland AB (2009) Why did contracts supplant the cash market in the broiler industry? An economic analysis featuring technological innovation and institutional response. J Agric Food Ind Organ. https://doi.org/10.2202/1542-0485.1146

Doblinger C, Dowling M, Helm R (2016) An institutional perspective of public policy and network effects in the renewable energy industry: enablers or disablers of entrepreneurial behaviour and innovation? Entrep Reg Dev 28:126-156. https://doi.org/10.1080/08985626.2015.1109004

Dodgson M (2009) Asia's national innovation systems: Institutional adaptability and rigidity in the face of global innovation challenges. Asia Pacific J Manag 26:589-609. https://doi.org/10.1007/ s10490-008-9105-4

Doloreux D, Dionne S, Lapointe D (2007) Institutional structure and modes of governance in non-metropolitan innovation systems. Int J Entrep Innov Manag 7:405-423. https://doi.org/10.1504/ijeim. 2007.012891

Domínguez-Escrig E, Mallén-Broch FF, Lapiedra-Alcamí R, Chiva-Gómez R (2019) The influence of leaders' stewardship behavior on innovation success: the mediating effect of radical innovation. J Bus Ethics 159:849-862. https://doi.org/10.1007/s10551-018-3833-2

Drenth PJD (1996) Institutional innovations in higher education. Ann N Y Acad Sci 798:223-237. https:// doi.org/10.1111/j.1749-6632.1996.tb24866.x

Drew SAW (1995) Strategic benchmarking: innovation practices in financial institutions. Int J Bank Mark 13:4-16. https://doi.org/10.1108/02652329510075418

Durugbo CM (2020) After-sales services and aftermarket support: a systematic review, theory and future research directions. Int J Prod Res 58:1857-1892. https://doi.org/10.1080/00207543.2019.1693655

Durugbo CM, Al-Jayyousi OR, Almahamid SM (2020a) Wisdom from Arabian Creatives: Systematic Review of Innovation Management Literature for the Gulf Cooperation Council (GCC) Region. Int J Innov Technol Manag 17:2030004-1-2030048. https://doi.org/10.1142/S0219877020300049

Durugbo CM, Amoudi O, Al-Balushi Z, Anouze AL (2020b) Wisdom from Arabian networks: a review and theory of regional supply chain management. Prod Plan Control. https://doi.org/10.1080/09537 287.2020.1796144

Ebegbulem CE (1974) Criteria for institutional innovation in teacher education. South Pacific J Teach Educ 2:28-32. https://doi.org/10.1080/0311213740020204

Edquist C (2006) Systems of innovation: perspectives and challenges. In: Fagerberg J, Mowery DC, Nelson RR (eds) The Oxford handbook of innovation. Oxford University Press, Oxford, pp 181-208

Edwards PN, King JL (2021) Institutions, Infrastructures, and Innovation. Computer (long Beach Calif) 54:103-109. https://doi.org/10.1109/MC.2020.3035921

Egan PJW (2013) R\&D in the periphery? Foreign direct investment, innovation, and institutional quality in developing countries. Bus Polit 15:1-32. https://doi.org/10.1515/bap-2012-0038

Elle SM (2017) Understanding microfinance institutions and commercial banks' relationships and innovations in the Cameroon financial environment. Strateg Chang 26:585-597. https://doi.org/10. $1002 /$ jsc. 2170

Epstein SR (1994) Regional fairs, institutional innovation, and economic growth in late medieval Europe. Econ Hist Rev 47:459-482. https://doi.org/10.1111/j.1468-0289.1994.tb01386.x

Ervits I, Zmuda M (2018) A cross-country comparison of the effects of institutions on internationally oriented innovation. J Int Entrep 16:486-503. https://doi.org/10.1007/s10843-018-0225-8

Escobal J (2000) Endogenous institutional innovation and agroindustrialization on the Peruvian coast. Agric Econ 23:267-277. https://doi.org/10.1016/S0169-5150(00)00088-8

Etzkowitz H, Germain-Alamartine E, Keel J et al (2019) Entrepreneurial university dynamics: Structured ambivalence, relative deprivation and institution-formation in the Stanford innovation system. Technol Forecast Soc Change 141:159-171. https://doi.org/10.1016/j.techfore.2018.10.019

Farrell KR, Runge CF (1983) Institutional innovation and technical change in american agriculture: The role of the new deal. Am J Agric Econ 65:1168-1173. https://doi.org/10.2307/1240442

Ferderer JP (2003) Institutional innovation and the creation of liquid financial markets: the case of bankers' acceptances, 1914-1934. J Econ Hist 63:666-694. https://doi.org/10.1017/S00220507035419 $5 \mathrm{X}$ 
Ferguson J-PJ-P, Carnabuci G (2017) Risky recombinations: institutional gatekeeping in the innovation process. Organ Sci 28:133-151. https://doi.org/10.1287/orsc.2016.1106

Filiou D, Golesorkhi S (2016) Influence of institutional differences on firm innovation from international alliances. Long Range Plann 49:129-144. https://doi.org/10.1016/j.lrp.2014.09.005

Fischer B, Tello-Gamarra J (2017) Institutional quality as a driver of efficiency in laggard innovation systems. J Glob Compet Governability 11:129-144. https://doi.org/10.3232/GCG.2017.V11.N1.06

Foray D, Woerter M (2021) The formation of Coasean institutions to provide university knowledge for innovation: a case study and econometric evidence for Switzerland. J Technol Transf 46:15841610. https://doi.org/10.1007/s10961-020-09828-z

Forde C (2020) Participatory governance in Ireland: Institutional innovation and the quest for joined-up thinking. Administration 68:1-20. https://doi.org/10.2478/admin-2020-0013

Frey BS, Lüthi R, Osterloh M (2012) Community enterprises-an institutional innovation. Manag Decis Econ 33:427-439. https://doi.org/10.1002/mde.2556

Fritsch M, Schwirten C (1999) Enterprise-university co-operation and the role of public research institutions in regional innovation systems. Ind Innov 6:69-83. https://doi.org/10.1080/1366271990 0000005

Fritsch S (2015) Technological innovation, globalization, and varieties of capitalism: the case of Siemens AG as example for contingent institutional adaptation. Bus Polit 17:125-159. https://doi.org/10. 1515/bap-2014-0020

Fuentelsaz L, Maicas JP, Montero J (2018) Entrepreneurs and innovation: the contingent role of institutional factors. Int Small Bus J Res Entrep 36:686-711. https://doi.org/10.1177/0266242618766235

Fullerton RA (1986) Understanding institutional innovation and system evolution in distribution. the contribution of Robert Nieschlag. Int J Res Mark 3:273-282. https://doi.org/10.1016/0167-8116(86) 90007-8

Fumasoli T, Rossi F (2021) The role of higher education institutions in transnational networks for teaching and learning innovation: the case of the Erasmus+ programme. Eur J Educ 56:200-218. https:// doi.org/10.1111/ejed.12454

Fung A (2012) Continuous institutional innovation and the pragmatic conception of democracy. Polity 44:609-624. https://doi.org/10.1057/pol.2012.17

Gachie W (2020) Higher education institutions, private sector and government collaboration for innovation within the framework of the Triple Helix Model. African J Sci Technol Innov Dev 12:203215. https://doi.org/10.1080/20421338.2019.1631120

Galindo-Martín M-A, Méndez-Picazo M-T, Castaño-Martínez M-S (2020) The role of innovation and institutions in entrepreneurship and economic growth in two groups of countries. Int J Entrep Behav Res 26:485-502. https://doi.org/10.1108/IJEBR-06-2019-0336

Gallery N, Gordon EA (2008) Sustainability in global financial reporting and innovation in institutions. Account Res J 21:231-238. https://doi.org/10.1108/10309610810922486

Gande A, John K, Nair VB, Senbet LW (2020) Taxes, institutions, and innovation: theory and international evidence. J Int Bus Stud 51:1413-1442. https://doi.org/10.1057/s41267-020-00375-1

Gao X, Zhai K, Qiu Y et al (2020) Innovation institution and spatial transfer of energy industry: the case of Jiangsu Province. China SAGE Open. https://doi.org/10.1177/2158244019900181

Gao Y, Gao S, Zhou Y, Huang K-F (2015) Picturing firms' institutional capital-based radical innovation under China's institutional voids. J Bus Res 68:1166-1175. https://doi.org/10.1016/j.jbusres.2014. 11.011

Gao Y, Shu C, Jiang X et al (2017) Managerial ties and product innovation: the moderating roles of macro- and micro-institutional environments. Long Range Plann 50:168-183. https://doi.org/10. 1016/j.lrp.2016.11.005

García JS, Velásquez JR (2013) Methodology for evaluating Innovation Capabilities at university institutions using a fuzzy system. J Technol Manag Innov 8:246-259. https://doi.org/10.4067/s071827242013000300051

Garrick D, Lane-Miller C, McCoy AL (2011) Institutional innovations to govern environmental water in the Western United States: lessons for Australia's Murray-Darling Basin. Econ Pap A J Appl Econ Policy 30:167-184. https://doi.org/10.1111/j.1759-3441.2011.00104.x

Garrone P, Grilli L, Mrkajic B (2018) The role of institutional pressures in the introduction of energyefficiency innovations. Bus Strateg Environ 27:1245-1257. https://doi.org/10.1002/bse.2072

Geels FW (2004) From sectoral systems of innovation to socio-technical systems: Insights about dynamics and change from sociology and institutional theory. Res Policy 33:897-920. https://doi.org/10. 1016/j.respol.2004.01.015 
Gehman J, Höllerer MA (2019) Venturing into the cultural future: research opportunities at the nexus of institutions, innovation and impact. Innov Manag Policy Pract 21:229-248. https://doi.org/10. $1080 / 14479338.2018 .1552520$

Genus A (2012) Changing the rules? Institutional innovation and the diffusion of microgeneration. Technol Anal Strateg Manag 24:711-727. https://doi.org/10.1080/09537325.2012.705122

George G, Prabhu GN (2003) Developmental financial institutions as technology policy instruments: implications for innovation and entrepreneurship in emerging economies. Res Policy 32:89-108. https://doi.org/10.1016/S0048-7333(02)00002-1

Gittelman M (2006) National institutions, public-private knowledge flows, and innovation performance: a comparative study of the biotechnology industry in the US and France. Res Policy 35:1052-1068. https://doi.org/10.1016/j.respol.2006.05.005

Godden D (1991) Induced institutional innovation: Plant variety rights, patents and genetic engineering. Oxford Agrar Stud 19:3-19. https://doi.org/10.1080/13600819108424032

Godlewska M (2021) The impact of interplay between formal and informal institutions on innovation performance: Evidence from ceecs. Eng Econ 32:15-26. https://doi.org/10.5755/j01.ee.32.1.27390

Goldsmith AA (1988) The management of institutional innovation: Lessons from transferring the land grant model to India. Public Adm Dev 8:317-330. https://doi.org/10.1002/pad.4230080306

Gongbuzeren ZJ, Zhuang M et al (2021) Mitigating the impacts of fragmented land tenure through community-based institutional innovations: Two case study villages from Guinan County of Qinghai Province. China Ecol Soc. https://doi.org/10.5751/ES-12326-260215

González-López M (2011) The institutions-innovation dilemma: the case of coastal fisheries. J Technol Manag Innov 6:184-195. https://doi.org/10.4067/S0718-27242011000300014

Grabowski R (1991) Agricultural development and institutional innovation: a view of early Japan. J Asian Econ 2:249-263. https://doi.org/10.1016/1049-0078(91)90038-M

Grabowski R (1988) The theory of induced institutional innovation: a critique. World Dev 16:385-394. https://doi.org/10.1016/0305-750X(88)90005-8

Gretchenko AI, Nikitskaya EF, Valishvili MA, Gretchenko AA (2018) Role of higher education institutions in developing hr potential in a forming innovation economy. Espacios 39(21):13

Gupta AK, Sinha R, Koradia D et al (2003) Mobilizing grassroots' technological innovations and traditional knowledge, values and institutions: articulating social and ethical capital. Futures 35:975987. https://doi.org/10.1016/S0016-3287(03)00053-3

Hage J, Hollingsworth JR (2000) A strategy for the analysis of idea innovation networks and institutions. Organ Stud 21:971-1004. https://doi.org/10.1177/0170840600215006

Hagel J, Brown JS (2013) Institutional innovation: Creating smarter organizations to scale learning. Deloitte Center Edge 12(5):1-22

Haggard S, Zheng Y (2013) Institutional innovation and investment in Taiwan: the micro-foundations of the developmental state. Bus Polit 15:435-466. https://doi.org/10.1515/bap-2012-0010

Halpern C (2005) Institutional change through innovation: The URBAN Community Initiative in Berlin, 1994-99. Environ Plan C Gov Policy 23:697-713. https://doi.org/10.1068/c0416

Hamdouch A, Moulaert F (2006) Knowledge infrastructure, innovation dynamics, and knowledge creation/diffusion/accumulation processes: a comparative institutional perspective. Innovation 19:2550. https://doi.org/10.1080/13511610600607676

Hao Z, Yunlong D (2014) Research on the relationship of institutional innovation, organizational learning and synergistic effect: An empirical study of Chinese university spin-offs. J Ind Eng Manag 7:645-659. https://doi.org/10.3926/jiem.950

Harding R (2000) Resilience in German technology policy: innovation through institutional symbiotic tension. Ind Innov 7:223-243. https://doi.org/10.1080/713670251

Hargadon AB, Douglas Y (2001) When innovations meet institutions: edison and the design of the electric light. Adm Sci Q 46:476-501. https://doi.org/10.2307/3094872

Hargrave TJ, Van De Ven AH (2006) A collective action model of institutional innovation. Acad Manag Rev 31:864-888. https://doi.org/10.5465/AMR.2006.22527458

Hart DM (2001) Antitrust and technological innovation in the US: ideas, institutions, decisions, and impacts, 1890-2000. Res Policy 30:923-936. https://doi.org/10.1016/S0048-7333(00)00165-7

Heher AD (2006) Return on investment in innovation: Implications for institutions and national agencies. J Technol Transf 31:403-414. https://doi.org/10.1007/s10961-006-0002-z

Helleiner E, Wang H (2018) Limits to the BRICS' challenge: credit rating reform and institutional innovation in global finance. Rev Int Polit Econ 25:573-595. https://doi.org/10.1080/09692290.2018. 1490330 
Hernández V, Nieto MJ, Rodríguez A (2021) Home country institutions and exports of firms in transition economies: Does innovation matter? Long Range Plann. https://doi.org/10.1016/j.lrp.2021.102087

Hinings B, Gegenhuber T, Greenwood R (2018) Digital innovation and transformation: an institutional perspective. Inf Organ 28:52-61. https://doi.org/10.1016/j.infoandorg.2018.02.004

Holloway G (2000) Agroindustrialization through institutional innovation transaction costs, cooperatives and milk-market development in the east-African highlands. Agric Econ 23:279-288. https://doi. org/10.1016/S0169-5150(00)00089-X

Hoque M, Chishty M, Halloway R (2011) Commercialization and changes in capital structure in microfinance institutions: An innovation or wrong turn? Manag Financ 37:414-425. https://doi.org/10. 1108/03074351111126906

Hoskisson RE, Hitt MA, Johnson RA, Grossman W (2002) Conflicting voices: the effects of institutional ownership heterogeneity and internal governance on corporate innovation strategies. Acad Manag J 45:697-716. https://doi.org/10.2307/3069305

Hou B, Hong J, Chen Q et al (2019) Do academia-industry R\&D collaborations necessarily facilitate industrial innovation in China?: The role of technology transfer institutions. Eur J Innov Manag 22:717-746. https://doi.org/10.1108/EJIM-09-2018-0195

Hou J, Chan EHW, Li LH (2018) Transfer of development rights as an institutional innovation to address issues of property rights. J Hous Built Environ 33:465-479. https://doi.org/10.1007/ s10901-018-9613-6

Hsu C, Lee J-N, Straub DW (2012) Institutional influences on information systems security innovations. Inf Syst Res 23:918-939. https://doi.org/10.1287/isre.1110.0393

Hu K (2014) The institutional innovation of the lender of last resort facility in the eurozone. J Eur Integr 36:627-640. https://doi.org/10.1080/07036337.2014.913039

Huang J, Ding J (2016) Institutional innovation and policy support to facilitate small-scale farming transformation in China. Agric Econ 47:227-237. https://doi.org/10.1111/agec.12309

Huang KG-LKG-L, Geng X, Wang H (2017) Institutional regime shift in intellectual property rights and innovation strategies of firms in China. Organ Sci 28:355-377. https://doi.org/10.1287/orsc.2017. 1117

Huang Y-C, Yang M-L (2014) Reverse logistics innovation, institutional pressures and performance. Manag Res Rev 37:615-641. https://doi.org/10.1108/MRR-03-2013-0069

Huber-Stearns HR, Schultz C, Cheng AS (2019) A multiple streams analysis of institutional innovation in forest watershed governance. Rev Policy Res 36:781-804. https://doi.org/10.1111/ropr.12359

Hueske A-K, Guenther E (2015) What hampers innovation? External stakeholders, the organization, groups and individuals: a systematic review of empirical barrier research. Manag Rev Q 65:113148. https://doi.org/10.1007/s11301-014-0109-5

Hug S (2005) The political effects of referendums: An analysis of institutional innovations in Eastern and Central Europe. Communist Post-Communist Stud 38:475-499. https://doi.org/10.1016/j.postc omstud.2005.09.006

Hughes I, Byrne E, Glatz-Schmallegger M et al (2021) Deep institutional innovation for sustainability and human development. World Futures 77:371-394. https://doi.org/10.1080/02604027.2021. 1929013

Hull A (1996) Strategic plan-making in Europe: institutional innovation. Plan Pract Res 11:253-264. https://doi.org/10.1080/02697459616834

Hung S-C (2000) Institutions and systems of innovation: an empirical analysis of Taiwan's personal computer competitiveness. Technol Soc 22:175-187. https://doi.org/10.1016/S0160-791X(00)00005-1

Hung S-CS-CS-C, Whittington R (2011) Agency in national innovation systems: Institutional entrepreneurship and the professionalization of Taiwanese IT. Res Policy 40:526-538. https://doi.org/10. 1016/j.respol.2011.01.008

Hüsig S, Mann H-G (2010) The role of promoters in effecting innovation in higher education institutions. Innov Manag Policy Pract 12:180-191. https://doi.org/10.5172/impp.12.2.180

Hussen MS, Çokgezen M (2021) Relationship between innovation, regional institutions and firm performance: Micro-evidence from Africa. African J Sci Technol Innov Dev. https://doi.org/10.1080/ 20421338.2020.1866148

Huston S, Rahimzad R, Parsa A (2015) "Smart" sustainable urban regeneration: institutions, quality and financial innovation. Cities 48:66-75. https://doi.org/10.1016/j.cities.2015.05.005

Hyvärinen J (2006) EU enlargement, institutional governance and innovation environment in the Baltic countries. J East-West Bus 12:39-70. https://doi.org/10.1300/J097v12n04_03 
Iqbal A (2021) Innovation speed and quality in higher education institutions: the role of knowledge management enablers and knowledge sharing process. J Knowl Manag. https://doi.org/10.1108/ JKM-07-2020-0546

Irlenbusch B, Leopold-Wildburger U, Schütze J, Sutter M (2003) Voting in EMU—an experimental study of institutional innovation and the role of communication in the stability and growth pact. JCMS J Common Mark Stud 41:645-664. https://doi.org/10.1111/1468-5965.00439

Ito J, Bao Z, Ni J (2016) Land rental development via institutional innovation in rural Jiangsu, China. Food Policy 59:1-11. https://doi.org/10.1016/j.foodpol.2015.12.005

Janssen MA, Ostrom E (2008) TURFS in the lab: institutional innovation in real-time dynamic spatial commons. Ration Soc 20:371-397. https://doi.org/10.1177/1043463108096786

Jansson F, Lindenfors P, Sandberg M (2013) Democratic revolutions as institutional innovation diffusion: Rapid adoption and survival of democracy. Technol Forecast Soc Change 80:1546-1556. https:// doi.org/10.1016/j.techfore.2013.02.002

Jayabalan J, Dorasamy M, Raman M (2021) Reshaping higher educational institutions through frugal open innovation. J Open Innov Technol Mark Complex. https://doi.org/10.3390/joitmc7020145

Jensen PH, Fersch B (2019) Institutional entrepreneurs and social innovation in danish senior care. Adm Soc 51:250-271. https://doi.org/10.1177/0095399715624945

Jiang X, Yuan Q (2018) Institutional investors' corporate site visits and corporate innovation. J Corp Financ 48:148-168. https://doi.org/10.1016/j.jcorpfin.2017.09.019

Jiang X, Zhang P (2020) Institutions, policies and diverse innovation systems: experiences from the US, Germany and South Korea. J Asian Public Policy 13:241-255. https://doi.org/10.1080/17516234. 2018.1541116

Johannessen J (2008) Explaining institutional change: aspects of an innovation in the new institutional economy. Kybernetes 37:20-35. https://doi.org/10.1108/03684920810850961

Jucevicius G, Juceviciene R, Gaidelys V, Kalman A (2016) The emerging innovation ecosystems and "Valley of death": Towards the combination of entrepreneurial and institutional approaches. Eng Econ 27:430-438. https://doi.org/10.5755/j01.ee.27.4.14403

Juk YV, Fuck MP (2015) Innovations and support institutions: The 1st geographical indication in Brazil. J Technol Manag Innov 10:117-126. https://doi.org/10.4067/S0718-27242015000200008

Jun K-NK-NK-NK-N, Weare C (2011) Institutional motivations in the adoption of innovations: the case of e-government. J Public Adm Res Theory 21:495-519. https://doi.org/10.1093/jopart/muq020

Jun Q, Dinçer H, Yüksel S (2021) Stochastic hybrid decision-making based on interval type 2 fuzzy sets for measuring the innovation capacities of financial institutions. Int J Financ Econ 26:573-593. https://doi.org/10.1002/ijfe.1805

Kadriu A, Krasniqi BA, Boari C (2019) The impact of institutions on SMEs' innovation in transition economies. Int J Entrep Innov Manag 23:399-424. https://doi.org/10.1504/IJEIM.2019.100804

Kafouros M, Wang C, Piperopoulos P, Zhang M (2015) Academic collaborations and firm innovation performance in China: the role of region-specific institutions. Res Policy 44:803-817. https://doi. org/10.1016/j.respol.2014.11.002

Kalinowski T (2020) Institutional innovations and their challenges in the green climate fund: country ownership, civil society participation and private sector engagement. Sustain 12:1-13. https://doi. org/10.3390/su12218827

Kalkabayeva G, Rakhmetova A, Doskaliyeva B et al (2021) The investments of financial institutions in real innovations: Kazakhstani practice. Intellect Econ 15:104-115. https://doi.org/10.13165/ IE-21-15-1-07

Kang Y, He X (2018) Institutional forces and environmental management strategy: moderating effects of environmental orientation and innovation capability. Manag Organ Rev 14:577-605. https://doi. org/10.1017/mor.2017.56

Kang Y, Jiang J (2020) Revisiting the innovation systems of cross-border cities: the role of higher education institution and cross-boundary cooperation in Hong Kong and Shenzhen. J High Educ Policy Manag 42:213-229. https://doi.org/10.1080/1360080X.2019.1701849

Kapetaniou C, Samdanis M, Lee SH (2018) Innovation policies of cyprus during the global economic crisis: aligning financial institutions with national innovation system. Technol Forecast Soc Change 133:29-40. https://doi.org/10.1016/j.techfore.2018.02.019 
Karaulova M, Shackleton O, Liu W et al (2017) Institutional change and innovation system transformation: A tale of two academies. Technol Forecast Soc Change 116:196-207. https://doi.org/10. 1016/j.techfore.2016.10.018

Kasper W (1994) Institutional innovation and the calculus of world competitiveness. Econ Anal Policy 24:37-55. https://doi.org/10.1016/S0313-5926(94)50003-1

Kasperavičiūtè-Černiauskienè R, Serafinas D (2018) The adoption of ISO 9001 standard within higher education institutions in lithuania: Innovation diffusion approach. Total Qual Manag Bus Excell 29:74-93. https://doi.org/10.1080/14783363.2016.1164012

Kawabata MK, Camargo Junior AS (2020) Innovation and institutions' quality: a comparative study between countries. Int J Innov Sci 12:169-185. https://doi.org/10.1108/IJIS-10-2019-0100

Khan A, Gulati R (2021) Productivity growth, catching-up and technology innovation in microfinance institutions in India: evidence using a bootstrap Malmquist Index approach. Benchmarking Int J Ahead-of-P. https://doi.org/10.1108/BIJ-10-2020-0535

Khan KS, Kunz R, Kleijnen J, Antes G (2003) Systematic reviews to support evidence-based medicine: how to review and apply findings of healthcare research. Royal Society of Medicine Press, London

Kidd RM (1996) Institutional innovations: the maine science and technology foundation as a public-private partnership for science-based economic growth. Ann N Y Acad Sci 798:123-126. https://doi.org/10.1111/j.1749-6632.1996.tb24860.x

Kikuchi M, Hayami Y (1983) New rice technology, intrarural migration, and institutional innovation in the Philippines. Popul Dev Rev 9:247. https://doi.org/10.2307/1973051

Kim H, Park K, Roy Song K (2019) Do long-term institutional investors foster corporate innovation? Account Financ 59:1163-1195. https://doi.org/10.1111/acfi.12284

King JL, Gurbaxani V, Kraemer KL et al (1994) Institutional factors in information technology innovation. Inf Syst Res 5:139-169. https://doi.org/10.1287/isre.5.2.139

Kitagawa F, Robertson S (2011) City-regions, innovation challenges and universities: New shifts in the UK urban governance institutions. Int J Knowledge-Based Dev 2:185-201. https://doi.org/ 10.1504/IJKBD.2011.041247

Kitchenham B, Charters S (2007) Guidelines for performing systematic literature reviews in software engineering

Knickel M, Neuberger S, Klerkx L et al (2021) Strengthening the role of academic institutions and innovation brokers in agri-food innovation: Towards hybridisation in cross-border cooperation. Sustain. https://doi.org/10.3390/su13094899

Kochhar R, David P (1996) Institutional investors and firm innovation: a test of competing hypotheses. Strateg Manag J 17:73-84. https://doi.org/10.1002/(SICI)1097-0266(199601)17:1\%3c73:: AID-SMJ795\%3e3.3.CO;2-E

Koh WTH (2006) Singapore's transition to innovation-based economic growth: infrastructure, institutions and government's role. R D Manag 36:143-160. https://doi.org/10.1111/j.1467-9310. 2006.00422.x

Kolk A, Lenfant F (2015) Cross-sector collaboration, institutional gaps, and fragility: the role of social innovation partnerships in a conflict-affected region. J Public Policy Mark 34:287-303. https://doi.org/10.1509/jppm.14.157

Kooijman M, Hekkert MP, van Meer PJK et al (2017) How institutional logics hamper innovation: the case of animal testing. Technol Forecast Soc Change 118:70-79. https://doi.org/10.1016/j.techf ore.2017.02.003

Kraft PS, Bausch A (2018) Managerial social networks and innovation: a meta-analysis of bonding and bridging effects across institutional environments. J Prod Innov Manag 35:865-889. https:// doi.org/10.1111/jpim. 12450

Krech M (2020) Towards equal rights in the global game? FIFA's strategy for women's football as a tightly bounded institutional innovation. Tilbg Law Rev 25:12-26. https://doi.org/10.5334/ TILR. 190

Krishnan RT, Jha SK (2012) Innovation in the Indian automotive industry: the role of academic and public research institutions. Asian J Technol Innov 20:67-84. https://doi.org/10.1080/19761 597.2012 .683945

Kruss G (2005) Harnessing innovation potential?: Institutional approaches to industry-higher education research partnerships in South Africa. Ind High Educ 19:131-142. https://doi.org/10.5367/ 0000000053729806 
Kukk P, Moors EHM, Hekkert MP (2016) Institutional power play in innovation systems: the case of Herceptin ${ }^{\circledR}$. Res Policy 45:1558-1569. https://doi.org/10.1016/j.respol.2016.01.016

Kumar V, Mudambi R, Gray S (2013) Internationalization, innovation and institutions: the 3 I's underpinning the competitiveness of emerging market firms. J Int Manag 19:203-206. https:// doi.org/10.1016/j.intman.2013.03.005

Kumari R, Kwon K-S, Lee B-H, Choi K (2020) Co-creation for social innovation in the ecosystem context: the role of higher educational institutions. Sustain 12:1-21. https://doi.org/10.3390/su120 10307

Kunamaneni S (2019) Challenges in moving from incremental to radical low-cost innovation in emerging and transition countries : institutional perspectives based on rechargeable battery innovation in China and point-of-use water purification innovation in India. Int J Innov Manag 23:1950028. https://doi.org/10.1142/S1363919619500282

Kwan LY-Y, Chiu C (2015) Country variations in different innovation outputs: the interactive effect of institutional support and human capital. J Organ Behav 36:1050-1070. https://doi.org/10.1002/job. 2017

Kwon M, Berry FS, Feiock RC (2009) Understanding the adoption and timing of economic development strategies in US cities using innovation and institutional analysis. J Public Adm Res Theory 19:967-988. https://doi.org/10.1093/jopart/mun026

Kwon S, Motohashi K (2017) How institutional arrangements in the national innovation system affect industrial competitiveness: a study of Japan and the U.S. with multiagent simulation. Technol Forecast Soc Change 115:221-235. https://doi.org/10.1016/j.techfore.2016.10.005

la Hiz DI, Hurtado-Torres N, Bermúdez-Edo M (2019) The heterogeneity of levels of green innovation by firms in international contexts: a study based on the home-country institutional profile. Organ Environ 32:508-527. https://doi.org/10.1177/1086026618761623

Landoni M (2017) Innovation policy in progress. Institutional intermediation in public procurement of innovation: satellite telecommunications in Italy. R D Manag 47:583-594. https://doi.org/10.1111/ $\operatorname{radm} .12246$

Lane J-E (1986) Institutional innovation and implementation: the case of Sweden. Policy Stud J 14:470477. https://doi.org/10.1111/j.1541-0072.1986.tb00746.x

Larsen K, Gunnarsson-Östling U, Westholm E (2011) Environmental scenarios and local-global level of community engagement: environmental justice, jams, institutions and innovation. Futures 43:413423. https://doi.org/10.1016/j.futures.2011.01.007

Laurell H (2018) An international new venture's commercialization of a medical technology innovation: the role of institutional healthcare settings. Int Mark Rev 35:136-163. https://doi.org/10.1108/ IMR-04-2015-0112

Lauto G, Bau M, Compagno C (2013) Individual and Institutional Drivers of Technology Transfer in Open Innovation. Ind High Educ 27:27-39. https://doi.org/10.5367/ihe.2013.0136

Lazer D, Mergel I, Ziniel C et al (2011) The Multiple Institutional Logics of Innovation. Int Public Manag J 14:311-340. https://doi.org/10.1080/10967494.2011.618308

Lee K-JK-J (2012) The coevolution of IT innovation and copyright institutions: the development of the mobile music business in Japan and Korea. J Strateg Inf Syst 21:245-255. https://doi.org/10.1016/j. jsis.2012.04.001

Lee SH, Yoo T (2008) Competing rationales for corporate governance in France: Institutional complementarities between financial markets and innovation systems. Corp Gov an Int Rev 16:63-76. https://doi.org/10.1111/j.1467-8683.2008.00669.x

Lee WC, Law SH (2017) Roles of formal institutions and social capital in innovation activities: a crosscountry analysis. Glob Econ Rev 46:203-231. https://doi.org/10.1080/1226508X.2017.1292859

Léopold M, Thébaud O, Charles A (2019) The dynamics of institutional innovation: crafting co-management in small-scale fisheries through action research. J Environ Manage 237:187-199. https://doi. org/10.1016/j.jenvman.2019.01.112

Levien RE (1971) Institutions, innovation, and incentives. IEEE Trans Educ 14:148-153. https://doi.org/ 10.1109/TE.1971.4320689

Li H, Sheng Y, Yan X (2020) Empirical research on the level of institutional innovation in the development of China's high-tech industry. IEEE Access 8:115800-115811. https://doi.org/10.1109/ ACCESS.2020.3003932 
Li J, Leeuwis C, Van BETL et al (2012) Contribution of action researching to institutional innovation: a case study of access and benefit sharing (ABS) mechanisms in the participatory plant breeding (PPB) in Southwest China. Int J Agric Resour Gov Ecol 9:204. https://doi.org/10.1504/IJARGE. 2012.050349

Li J, Xing J (2020) Why Is collaborative agglomeration of innovation so important for improving regional innovation capabilities? A perspective based on collaborative agglomeration of industry-universityresearch institution. Complexity. https://doi.org/10.1155/2020/7049606

Li X (2015) Specialization, institutions and innovation within China's regional innovation systems. Technol Forecast Soc Change 100:130-139. https://doi.org/10.1016/j.techfore.2015.06.032

Liao Z (2018) Institutional pressure, knowledge acquisition and a firm's environmental innovation. Bus Strateg Environ 27:849-857. https://doi.org/10.1002/bse.2036

Lin JY (1995) Endowments, technology, and factor markets: a natural experiment of induced institutional innovation from China's rural reform. Am J Agric Econ 77:231-242. https://doi.org/10.2307/ 1243533

Lindelöf P (2011) Formal institutional contexts as ownership of intellectual property rights and their implications for the organization of commercialization of innovations at universities comparative data from Sweden and the United Kingdom. Int J Innov Manag 15:1069-1092. https://doi.org/10. 1142/S1363919611003611

Lisowska R, Stanisławski R (2014) Institutional support system for the development of SME innovation. Int J Innov Learn 16:319-337. https://doi.org/10.1504/IJIL.2014.064734

Liu FF-CF, Simon DF, Sun Y, Cao C (2011) China's innovation policies: Evolution, institutional structure, and trajectory. Res Policy 40:917-931. https://doi.org/10.1016/j.respol.2011.05.005

Liu J (2016) Regional institutions and their impact on the connectedness of firm's innovation networks. Institutions Econ 8:102-129

Llopis O, D'Este P (2016) Beneficiary contact and innovation: The relation between contact with patients and medical innovation under different institutional logics. Res Policy 45:1512-1523. https://doi. org/10.1016/j.respol.2016.03.004

Lobe K, Berkes F (2004) The padu system of community-based fisheries management: change and local institutional innovation in south India. Mar Policy 28:271-281. https://doi.org/10.1016/S0308597X(03)00087-3

Lounsbury M, Crumley ET (2007) New practice creation: an institutional perspective on innovation: Michael Lounsbury and Ellen T. Crumley Organ Stud 28:993-1012. https://doi.org/10.1177/01708 40607078111

Lui AKH, Ngai EWT, Lo CKY (2016) Disruptive information technology innovations and the cost of equity capital: The moderating effect of CEO incentives and institutional pressures. Inf Manag 53:345-354. https://doi.org/10.1016/j.im.2015.09.009

Lund HB, Karlsen A (2020) The importance of vocational education institutions in manufacturing regions: adding content to a broad definition of regional innovation systems. Ind Innov 27:660679. https://doi.org/10.1080/13662716.2019.1616534

Lynn LH, Reddy NM, Aram JD (1996) Linking technology and institutions: the innovation community framework. Res Policy 25:91-106. https://doi.org/10.1016/0048-7333(94)00817-5

Lyu L, Wu W, Hu H, Huang R (2019) An evolving regional innovation network: collaboration among industry, university, and research institution in China's first technology hub. J Technol Transf 44:659-680. https://doi.org/10.1007/s10961-017-9620-x

Ma X-F, Kaldenbach M, Katzy B (2014) Cross-border innovation intermediaries - matchmaking across institutional contexts. Technol Anal Strateg Manag 26:703-716. https://doi.org/10.1080/09537325. 2014.899346

Ma Z, Yu M, Gao C et al (2015) Institutional constraints of product innovation in China: evidence from international joint ventures. J Bus Res 68:949-956. https://doi.org/10.1016/j.jbusres.2014.09.022

Magalhães CS (2004) Centres of excellence for urban regeneration: promoting institutional capacity and innovation or reaffirming old ideas? Plan Theory Pract 5:33-47. https://doi.org/10.1080/14649 35042000185053

Magnier-Watanabe R, Senoo D (2009) The effect of institutional pressures on knowledge management and the resulting innovation: the case of the smartcard in France. Int J Intell Enterp 1:177-197. https://doi.org/10.1504/IJIE.2009.024410

Maksimov V, Wang SL, Luo Y (2017) Institutional imprinting, entrepreneurial agency, and private firm innovation in transition economies. J World Bus 52:854-865. https://doi.org/10.1016/j.jwb.2017. 06.002 
Malen J, Vaaler PM (2017) Organizational slack, national institutions and innovation effort around the world. J World Bus 52:782-797. https://doi.org/10.1016/j.jwb.2017.07.001

Mandal MAS (1987) Imperfect institutional innovation for irrigation management in Bangladesh. Irrig Drain Syst 1:239-258. https://doi.org/10.1007/BF01102933

Markey-Towler B (2020) Blockchains and institutional competition in innovation systems. J Entrep Public Policy 9:185-193. https://doi.org/10.1108/JEPP-03-2019-0015

Martin G, Siebert S, Robson I (2018) Conformist innovation: an institutional logics perspective on how HR executives construct business school reputations. Int J Hum Resour Manag 29:2027-2053. https://doi.org/10.1080/09585192.2016.1239118

Martin MJC (1994) Managing innovation and entrepreneurship in technology-based firms. Wiley, New York

Martínez-Pérez Á, Elche D, García-Villaverde PM, Parra-Requena G (2019) Cultural tourism clusters: social capital, relations with institutions, and radical innovation. J Travel Res 58:793-807. https:// doi.org/10.1177/0047287518778147

Mason G, Wagner K (1999) Knowledge transfer and innovation in Germany and Britain: "Intermediate institution" models of knowledge transfer under strain? Ind Innov 6:85-109. https://doi.org/10. $1080 / 13662719900000006$

Matzner E (1985) Technological and institutional innovation. Ann Public Coop Econ 56:71-80. https:// doi.org/10.1111/j.1467-8292.1985.tb01980.x

May C, Schedelik M (2019) Comparative capitalism and innovation policy: complementarities and comparative institutional advantage. J Econ Policy Reform. https://doi.org/10.1080/17487870.2019. 1637589

May PH (2008) Overcoming contradictions between growth and sustainability: institutional innovation in the BRICS. Chinese J Popul Resour Environ 6:3-13. https://doi.org/10.1080/10042857.2008. 10684876

McCann L (2004) Induced institutional innovation and transaction costs: the case of the Australian National native title Tribunal. Rev Soc Econ 62:67-82. https://doi.org/10.1080/003467604200018 3835

McCarthy DJ, Puffer SM, Graham LR, Satinsky DM (2014) Emerging innovation in emerging economies: Can institutional reforms help Russia break through its historical barriers? Thunderbird Int Bus Rev 56:243-260. https://doi.org/10.1002/tie.21619

Mehmood A (2016) Institutional forms of social innovation. Int J Innov Sustain Dev 10:300-311. https:// doi.org/10.1504/IJISD.2016.077512

Menzies J (2013) Reducing tensions in Australian intergovernmental relations through institutional innovation. Aust J Public Adm 72:382-389. https://doi.org/10.1111/1467-8500.12036

Mia MA (2020) Technological change and innovations in microfinance institutions: what matters? Glob Bus Rev. https://doi.org/10.1177/0972150920927368

Minh TT, Hjortsø CN (2015) How institutions influence SME innovation and networking practices: the case of vietnamese agribusiness. J Small Bus Manag 53:209-228. https://doi.org/10.1111/jsbm. 12189

Mishchenko S, Naumenkova S, Mishchenko V, Dorofeiev D (2021) Innovation risk management in financial institutions. Invest Manag Financ Innov 18:191-203. https://doi.org/10.21511/imfi.18(1).2021. 16

Mohsen K, Saeed S, Raza A et al (2021) Does using latest technologies impact new venture innovation? A contingency-based view of institutional environments. J Small Bus Manag 59:852-886. https:// doi.org/10.1111/jsbm.12534

Molina-Morales FX, Mas-Verdu F (2008) Intended ties with local institutions as factors in innovation: an application to spanish manufacturing firms. Eur Plan Stud 16:811-827. https://doi.org/10.1080/ 09654310802079452

Molnár I (2004) Legal and institutional aspects of the innovation system of the European integration. Period Polytech Soc Manag Sci 12:103-122

Monteiro S, Isusi-Fagoaga R, Almeida L, García-Aracil A (2021) Contribution of higher education institutions to social innovation: Practices in two southern european universities. Sustain. https://doi. org/10.3390/su13073594 
Moon H, Mariadoss BJ, Johnson JL (2019) Collaboration with higher education institutions for successful firm innovation. J Bus Res 99:534-541. https://doi.org/10.1016/j.jbusres.2017.09.033

Moore G (2011) Institutional Innovation: re-invigorating the university through transdisciplinary engagement. Triplec Commun Capital Crit Open Access J Glob Sustain Inf Soc 9:598-609. https://doi. org/10.31269/triplec.v9i2.198

Mosconi F, D'Ingiullo D (2021) Institutional quality and innovation: evidence from Emilia-Romagna. Econ Innov New Technol. https://doi.org/10.1080/10438599.2021.1893140

Mueller V, Rosenbusch N, Bausch A (2013) Success patterns of exploratory and exploitative innovation: a meta-analysis of the influence of institutional factors. J Manage 39:1606-1636. https://doi.org/10. $1177 / 0149206313484516$

Munene JC (1995) The institutional environment and managerial innovations: a qualitative study of selected Nigerian firms. J Occup Organ Psychol 68:291-300. https://doi.org/10.1111/j.2044-8325. 1995.tb00588.x

Mutenje M, Kankwamba H, Mangisonib J, Kassie M (2016) Agricultural innovations and food security in Malawi: Gender dynamics, institutions and market implications. Technol Forecast Soc Change 103:240-248. https://doi.org/10.1016/j.techfore.2015.10.004

Na LJ, Ofori G, Ling FYY, Hua GB (2007) Role of national institutions in promoting innovation by contractors in Singapore. Constr Manag Econ 25:1021-1039. https://doi.org/10.1080/0144619070 1209925

Nagamatsu A, Watanabe C, Shum KL (2006) Diffusion trajectory of self-propagating innovations interacting with institutions-incorporation of multi-factors learning function to model PV diffusion in Japan. Energy Policy 34:411-421. https://doi.org/10.1016/j.enpol.2004.06.010

Nakamura L, Born SM (1993) Substate institutional innovation for managing lakes and watersheds: a Wisconsin case study. J Am Water Resour Assoc 29:807-821. https://doi.org/10.1111/j.1752-1688. 1993.tb03240.x

Nam D-IDD-I, Parboteeah KP, Cullen JB, Johnson JL (2014) Cross-national differences in firms undertaking innovation initiatives: an application of institutional anomie theory. J Int Manag 20:91-106. https://doi.org/10.1016/j.intman.2013.05.001

Nelson RR, Nelson K (2002) Technology, institutions, and innovation systems. Res Policy 31:265-272. https://doi.org/10.1016/S0048-7333(01)00140-8

Nielsen JR, Degnbol P, Viswanathan KK et al (2004) Fisheries co-management—an institutional innovation? Lessons from South East Asia and Southern Africa. Mar Policy 28:151-160. https://doi.org/ $10.1016 / \mathrm{S} 0308-597 \mathrm{X}(03) 00083-6$

Nieto M, González-Álvarez N (2014) Product innovation: testing the relative influence of industry, institutional context and firm factors. Technol Anal Strateg Manag 26:1023-1036. https://doi.org/10. $1080 / 09537325.2014 .944146$

Nikolaou IE, Evangelinos KI, Leal Filho W (2010) Intellectual property and environmental innovation: an explanation using the institutional and resource-based theories. Int J Foresight Innov Policy 6:268-281. https://doi.org/10.1504/IJFIP.2010.037472

Niosi J (2010) Rethinking science, technology and innovation (STI) institutions in developing countries. Innov Manag Policy Pract 12:250-268. https://doi.org/10.5172/impp.12.3.250

Nite C, Washington M (2017) Institutional adaptation to technological innovation: Lessons from the NCAA's regulation of football television broadcasts (1938-1984). J Sport Manag 31:575-590. https://doi.org/10.1123/jsm.2017-0159

Nkundabanyanga SK, Mugumya E, Nalukenge I et al (2020) Firm characteristics, innovation, financial resilience and survival of financial institutions. J Acc Emerg Econ 10:48-73. https://doi.org/10. 1108/JAEE-08-2018-0094

Nolan P, Xiaoqiang W (1999) Beyond privatization: Institutional innovation and growth in China's large state-owned enterprises. World Dev 27:169-200. https://doi.org/10.1016/S0305-750X(98)00132-6

Nooteboom B (2000) Institutions and forms of co-ordination in innovation systems. Organ Stud 21:915939. https://doi.org/10.1177/0170840600215004

Nordberg M, Campbell A, Verbeke A (2003) Using customer relationships to acquire technological innovation. A value-chain analysis of supplier contracts with scientific research institutions. J Bus Res 56:711-719. https://doi.org/10.1016/S0148-2963(01)00256-9

North DC (1991) Institutions. J Econ Perspect 5:97-112. https://doi.org/10.1257/jep.5.1.97

North DC (1990) Institutions, institutional change and economic performance. Cambridge University Press, Cambridge 
Nyseth T, Ventura López TD (2021) Innovations in urban integration policies: immigrant councils as democratic institutions. Cities. https://doi.org/10.1016/j.cities.2021.103389

Oborn E, Pilosof NP, Hinings B, Zimlichman E (2021) Institutional logics and innovation in times of crisis: telemedicine as digital 'PPE.' Inf Organ 31:100340. https://doi.org/10.1016/j.infoandorg.2021. 100340

OECD/Eurostat (2018) Oslo Manual 2018: Guidelines for Collecting, Reporting and Using Data on Innovation, 4th Edition, The Measurement of Scientific, Technological and Innovation Activities. OECD Publishing, Paris

Oi WY (2004) The supermarket: an institutional innovation. Aust Econ Rev 37:337-342. https://doi.org/ 10.1111/j.1467-8462.2004.00335.x

Onsongo E (2019) Institutional entrepreneurship and social innovation at the base of the pyramid: the case of M-Pesa in Kenya. Ind Innov 26:369-390. https://doi.org/10.1080/13662716.2017.1409104

Oppong N (2016) The twists and turns of institutional innovation in small island developing states: the case of Tuvalu. Commonw Comp Polit 54:23-45. https://doi.org/10.1080/14662043.2015.1124498

Oppong N, Andrews N (2020) Extractive industries transparency initiative and the politics of institutional innovation in Ghana's oil industry. Extr Ind Soc 7:1238-1245. https://doi.org/10.1016/j.exis.2020. 05.013

Orihata M, Watanabe C (2000) The interaction between product concept and institutional inducement: a new driver of product innovation. Technovation 20:11-23. https://doi.org/10.1016/S0166-4972(99) 00107-8

Ottenbacher MC, Harrington RJ (2009) Institutional, cultural and contextual factors: potential drivers of the culinary innovation process. Tour Hosp Res 9:235-249. https://doi.org/10.1057/thr.2009.8

Oyelaran-Oyeyinka B (2006) Systems of innovation and underdevelopment. Sci Technol Soc 11:239269. https://doi.org/10.1177/097172180601100201

Parrado S (2008) Failed policies but institutional innovation through "layering" and "diffusion" in Spanish central administration. Int J Public Sect Manag 21:230-252. https://doi.org/10.1108/09513 550810855672

Parto S (2008) Innovation and economic activity: An institutional analysis of the role of clusters in industrializing economies. J Econ Issues 42:1005-1030. https://doi.org/10.1080/00213624.2008.11507 200

Pascucci S, De Magistris T (2011) Institutional innovation and public extension services provision: the marche regional administration reform in central Italy. J Agric Educ Ext 17:267-281. https://doi. org/10.1080/1389224X.2011.559081

Patel S, Burra S (1994) Access to housing finance for the urban poor. Institutional Innovations in India. Cities 11:393-397. https://doi.org/10.1016/0264-2751(94)90072-8

Patterson JJ, Huitema D (2019) Institutional innovation in urban governance: The case of climate change adaptation. J Environ Plan Manag 62:374-398. https://doi.org/10.1080/09640568.2018.1510767

Pearson R, Richardson D (2008) Social capital, institutional innovation and Atlantic trade before 1800. Bus Hist 50:765-780. https://doi.org/10.1080/00076790802420336

Peirce WS (1991) Innovation and diffusion in the "Single Europe". Institutional structure and industrial prospects for the European Communities. Technol Forecast Soc Change 39:35-44. https://doi.org/ 10.1016/0040-1625(91)90027-D

Perry KK (2021) Innovation, institutions and development: A critical review and grounded heterodox economic analysis of late-industrialising contexts. Cambridge J Econ 44:391-415. https://doi.org/ 10.1093/CJE/BEZ049

Pesti P, Effendi N, Cahyandito MF (2019) The influence of institution partnership and innovation management on the smart city reputation. J Entrep Educ 22(3):1-11

Petruzzelli AM, Rotolo D (2015) Institutional diversity, internal search behaviour, and joint-innovations. Manag Decis 53:2088-2106. https://doi.org/10.1108/MD-05-2014-0256

Pfister C, Koomen M, Harhoff D, Backes-Gellner U (2021) Regional innovation effects of applied research institutions. Res Policy. https://doi.org/10.1016/j.respol.2021.104197

Phakathi S, Sinyolo S, Marire J, Fraser G (2021) Farmer-led institutional innovations in managing smallholder irrigation schemes in KwaZulu-Natal and Eastern Cape Provinces. South Africa Agric Water Manag. https://doi.org/10.1016/j.agwat.2021.106780 
Phornlaphatrachakorn K (2019) Effects of transformational leadership, organisational learning and technological innovation on strategic management accounting in thailand's financial institutions. Asian J Bus Account 12:165-188. https://doi.org/10.22452/ajba.vol12no1.6

Piana BD, Vecchi A, Vivacqua E (2015) Innovation, institutions and cultures: exploring the European context. Manag Rev 26:5-24. https://doi.org/10.1688/mrev-2015-01-Della-Piana

Pinho JC (2017) Institutional theory and global entrepreneurship: exploring differences between factor- versus innovation-driven countries. J Int Entrep 15:56-84. https://doi.org/10.1007/ s10843-016-0193-9

Pistor K (2009) Global network finance: institutional innovation in the global financial market place. J Comp Econ 37:552-567. https://doi.org/10.1016/j.jce.2009.08.002

Polopolus L (1969) On institutional obsolescence and innovation. Am J Agric Econ 51:1624-1628. https://doi.org/10.2307/1238060

Polzin F, von Flotow P, Klerkx L (2016) Addressing barriers to eco-innovation: exploring the finance mobilisation functions of institutional innovation intermediaries. Technol Forecast Soc Change 103:34-46. https://doi.org/10.1016/j.techfore.2015.10.001

Pred A (1978) The impact of technological and institutional innovations on life content: some time-geographic observations. Geogr Anal 10:345-372. https://doi.org/10.1111/j.1538-4632.1978.tb006 64. $x$

Qing Y, Chen M, Sheng Y, Huang J (2019) Mechanization services, farm productivity and institutional innovation in China. China Agric Econ Rev 11:536-554. https://doi.org/10.1108/ CAER-12-2018-0244

Qu Y, Qu T, Wu Y (2017) The role of regional formal institutions and foreign direct investment in innovation in Chinese enterprises. Asia Pacific Bus Rev 23:27-43. https://doi.org/10.1080/13602381. 2015.1094293

Quiroga MC, Martin DP (2017) Technology foresight in traditional Bolivian sectors: innovation traps and temporal unfit between ecosystems and institutions. Technol Forecast Soc Change 119:280-293. https://doi.org/10.1016/j.techfore.2016.06.023

Radaelli G, Currie G, Frattini F, Lettieri E (2017) The role of managers in enacting two-step institutional work for radical innovation in professional organizations. J Prod Innov Manag 34:450-470. https:// doi.org/10.1111/jpim.12385

Raffaelli R, Glynn MA (2015) Institutional innovation: novel, useful, and legitimate. In: Shalley C, Hitt MA, Zhou J (eds) The Oxford handbook of creativity, innovation, and entrepreneurship. Oxford University Press, Oxford, pp 407-420

Raghubanshi G, Venugopal S, Saini GK (2021) Fostering inclusive social innovation in subsistence marketplaces through community-level alliances: an institutional work perspective. Ind Mark Manag 97:21-34. https://doi.org/10.1016/j.indmarman.2021.06.009

Rahman MM, Khan MA, Mohammad N, Rahman MO (2009) Cyberspace claiming new dynamism in the jurisprudential philosophy. Int J Law Manag 51:274-290. https://doi.org/10.1108/1754243091 0988883

Rahman HM, Sherren K, van Proosdij D (2019) Institutional Innovation for Nature-Based Coastal Adaptation: Lessons from Salt Marsh Restoration in Nova Scotia. Canada. Sustainability 11:6735. https://doi.org/10.3390/su11236735

Ransdell J (2019) Institutional innovation by the Asian infrastructure investment bank. Asian J Int Law 9:125-152. https://doi.org/10.1017/S2044251318000176

Rasiah R (1996) Innovation and institutions: moving towards the technological frontier in the electronics industry in Malaysia. J Ind Stud 3:78-102

Rasiah R, Shahrivar RB, Yap X-S (2016) Institutional support, innovation capabilities and exports: evidence from the semiconductor industry in Taiwan. Technol Forecast Soc Change 109:69-75. https://doi.org/10.1016/j.techfore.2016.05.015

Reed M, Wallace M (2015) Elite discourse and institutional innovation: making the hybrid happen in English public services. Res Sociol Organ 43:269-302. https://doi.org/10.1108/S0733-558X2 0150000043022

Regan PM (1993) Data integrity boards: institutional innovation and congressional oversight. Gov Inf Q 10:443-459. https://doi.org/10.1016/0740-624X(93)90040-7

Riccomini FE, Cirani CBS, Pedro SDC et al (2021) Innovation in educational marketing: a study applied to Brazilian private higher education institutions. J Mark High Educ. https://doi.org/10.1080/08841 241.2021.1966157 
Richardson J (1979) Institutional innovation: organizing for better international relationships. Ann Am Acad Pol Soc Sci 442:117-124. https://doi.org/10.1177/000271627944200114

Rickards T, De Cock C, Moger S et al (1996) Process: Implementation as a form of institutional innovation. Creat Innov Manag 5:252-259. https://doi.org/10.1111/j.1467-8691.1996.tb00151.x

Robin S, Schubert T (2013) Cooperation with public research institutions and success in innovation: evidence from France and Germany. Res Policy 42:149-166. https://doi.org/10.1016/j.respol.2012.06. 002

Rodima-Taylor D, Olwig MF, Chhetri N (2012) Adaptation as innovation, innovation as adaptation: an institutional approach to climate change. Appl Geogr 33:107-111. https://doi.org/10.1016/j. apgeog.2011.10.011

Rodríguez-Pose A, Zhang M (2020) The cost of weak institutions for innovation in China. Technol Forecast Soc Change. https://doi.org/10.1016/j.techfore.2020.119937

Rolfstam M (2012) An institutional approach to research on public procurement of innovation. Innov Eur J Soc Sci Res 25:303-321. https://doi.org/10.1080/13511610.2012.717475

Rong Z, Wu X, Boeing P (2017) The effect of institutional ownership on firm innovation: evidence from Chinese listed firms. Res Policy 46:1533-1551. https://doi.org/10.1016/j.respol.2017.05.013

Rosário FJP, Santa Rita LP, de Albuquerque PP (2013) Technology, relationship and support institutions on sectoral systems of innovation and production in Brazil's northwest bio ethanol and sugar agroindustry. J Technol Manag Innov 8:285-303

Rosenbusch N, Gusenbauer M, Hatak I et al (2019) Innovation offshoring, institutional context and innovation performance: a meta-analysis. J Manag Stud 56:203-233. https://doi.org/10.1111/joms. 12407

Ross SA (1989) Institutional markets, financial marketing, and financial innovation. J Finance 44:541. https://doi.org/10.2307/2328769

Ruan L, Liu H (2021) The impact of institutional innovation on internal control: evidence from Chinese state-owned enterprises. Int J Technol Manag 85:255-273. https://doi.org/10.1504/IJTM.2021. 115264

Rutherford TD (2001) The state of training: learning, institutional innovation, and local boards for training and adjustment in Ontario, Canada. Environ Plan A Econ Sp 33:1871-1891. https://doi.org/10. 1068/a33209

Ruttan VW (1989) Institutional innovation and agricultural development. World Dev 17:1375-1387. https://doi.org/10.1016/0305-750X(89)90079-X

Ruttan VW (2006) Social science knowledge and induced institutional innovation: an institutional design perspective. J Institutional Econ 2:249-272. https://doi.org/10.1017/S1744137406000403

Ruttan VW, Hayami Y (1984) Toward a theory of induced institutional innovation. J Dev Stud 20:203223. https://doi.org/10.1080/00220388408421914

Saka-Helmhout A, Chappin M, Vermeulen P (2020) Multiple paths to firm innovation in sub-saharan Africa: how informal institutions matter. Organ Stud 41:1551-1575. https://doi.org/10.1177/01708 40619882971

Sakaki H, Jory SR (2019) Institutional investors' ownership stability and firms' innovation. J Bus Res 103:10-22. https://doi.org/10.1016/j.jbusres.2019.05.032

Salandra R (2018) Knowledge dissemination in clinical trials: exploring influences of institutional support and type of innovation on selective reporting. Res Policy 47:1215-1228. https://doi.org/10. 1016/j.respol.2018.04.005

Sandberg M (2007) The evolution of IT innovations in Swedish organizations: a Darwinian critique of "Lamarckian" institutional economics. J Evol Econ 17:1-23. https://doi.org/10.1007/ s00191-006-0029-1

Sanginga PC, Abenakyo A, Kamugisha R et al (2010) Tracking outcomes of social capital and institutional innovations in natural resources management: methodological issues and empirical evidence from participatory Bylaw Reform in Uganda. Soc Nat Resour 23:711-725. https://doi.org/10.1080/ 08941920802192207

Sartor MA, Beamish PW (2014) Offshoring innovation to emerging markets: organizational control and informal institutional distance. J Int Bus Stud 45:1072-1095. https://doi.org/10.1057/jibs.2014.36

Sawang S, Zhou Y, Yang X (2017) Does institutional context matter in building innovation capability? Int J Technol Learn Innov Dev 9:153-168. https://doi.org/10.1504/IJTLID.2017.084933

Schickler E (2001) Disjointed pluralism: institutional innovation and the development of the US Congress. Princeton University Press, Princeton 
Schofield N (2000) Institutional innovation, contingency and war: a review. Soc Choice Welfare 17:463479. https://doi.org/10.1007/s003550050173

Schøtt T, Jensen KW (2016) Firms' innovation benefiting from networking and institutional support: A global analysis of national and firm effects. Res Policy 45:1233-1246. https://doi.org/10.1016/j. respol.2016.03.006

Schütz F, Schroth F, Muschner A, Schraudner M (2018) Defining functional roles for research institutions in helix innovation networks. J Technol Manag Innov 13:47-53. https://doi.org/10.4067/S071827242018000400047

Scott WR (2006) Institutions and organisations. Sage, Thousand Oaks

Sein-Echaluce ML, Abadía-Valle AR, Bueno-García C, Fidalgo-Blanco Á (2017) Interaction of knowledge spirals to create ontologies for an institutional repository of educational innovation best practices. Int J Hum Cap Inf Technol Prof 8:72-92. https://doi.org/10.4018/IJHCITP.2017040105

Sena V, Marra M, Demirbag M, Lubrano Lavadera G (2021) The Impact of Institutions on Collaborative Innovations and the Role of Equity-Based Entry Modes. Br J Manag. https://doi.org/10.1111/14678551.12511

Sewell WRD, Coppock JT, Pitkethly A (2005) Institutional innovation in water management: the Scottish experience. Routledge, London

Sha K, Song T, Qi X, Luo N (2006) Rethinking China's urbanization: an institutional innovation perspective. Build Res Inf 34:573-583. https://doi.org/10.1080/09613210600852730

Shackleton M, Raunio T (2003) Codecision since Amsterdam: a laboratory for institutional innovation and change. J Eur Public Policy 10:171-188. https://doi.org/10.1080/1350176032000058982

Shaffer JD (1969) On institutional obsolescence and innovation-background for professional dialogue on public policy. Am J Agric Econ 51:245-267. https://doi.org/10.2307/1237577

Shang Y, Fagan M (2006) Catalysing institutional innovation. Int J Technol Glob 2:340. https://doi.org/ 10.1504/IJTG.2006.011921

Sharma MK, Sharma RC (2021) Innovation framework for excellence in higher education institutions. Glob J Flex Syst Manag 22:141-155. https://doi.org/10.1007/s40171-021-00265-x

Sharma U, Lawrence S, Lowe A (2010) Institutional contradiction and management control innovation: A field study of total quality management practices in a privatized telecommunication company. Manag Account Res 21:251-264. https://doi.org/10.1016/j.mar.2010.03.005

Shin D-H (2004) Inter-institutional communications and process innovation: inter-institutional system and collaborative work process. J Comput Inf Technol 12:55. https://doi.org/10.2498/cit.2004.01. 05

Shu C, Zhou KZ, Xiao Y, Gao S (2016) How green management influences product innovation in China: the role of institutional benefits. J Bus Ethics 133:471-485. https://doi.org/10.1007/ s10551-014-2401-7

Siltaloppi J, Koskela-Huotari K, Vargo SL (2016) Institutional complexity as a driver for innovation in service ecosystems. Serv Sci 8:333-343. https://doi.org/10.1287/serv.2016.0151

Simmie J, Strambach S (2006) The contribution of KIBS to innovation in cities: an evolutionary and institutional perspective. J Knowl Manag 10:26-40. https://doi.org/10.1108/13673270610691152

Simpson J (2005) Cooperation and conflicts: institutional innovation in France's wine markets, 18701911. Bus Hist Rev 79:527-558. https://doi.org/10.1017/S0007680500081435

Singh VP, Allen T (2006) Institutional contexts for scientific innovation and economic transformation. Eur Plan Stud 14:665-679. https://doi.org/10.1080/09654310500500205

Smink MM, Hekkert MP, Negro SO (2015) Keeping sustainable innovation on a leash? Exploring incumbents' institutional strategies. Bus Strateg Environ 24:86-101. https://doi.org/10.1002/bse.1808

Smith N, Thomas E (2015) Socio-institutional environment and innovation in Russia. J East-West Bus 21:182-204. https://doi.org/10.1080/10669868.2015.1021066

Styhre A, Remneland-Wikhamn B (2016) The institutional work of life science innovation leadership: the case of a bio venture hub. Qual Res Organ Manag an Int J 11:253-275. https://doi.org/10.1108/ QROM-10-2015-1331

Sun F, Hong J, Ma X, Wang C (2017) Subnational institutions and open innovation: evidence from China. Manag Decis 55:1942-1955. https://doi.org/10.1108/MD-11-2016-0781

Suparjo ESS (2017) Professional competence and service innovation in higher education institutions in central Java, Indonesia. Eur Res Stud J XX:622-636. https://doi.org/10.35808/ersj/916 
Sus M (2019) Institutional innovation of EU's foreign and security policy: Big leap for EU's strategic actorness or much ADO about nothing? Int Polit 56:411-425. https://doi.org/10.1057/ s41311-017-0133-X

Suzuki M (2015) Identifying roles of international institutions in clean energy technology innovation and diffusion in the developing countries: matching barriers with roles of the institutions. J Clean Prod 98:229-240. https://doi.org/10.1016/j.jclepro.2014.08.070

Tang Y, Hu X, Petti C, Thürer M (2020a) Institutional incentives and pressures in Chinese manufacturing firms' innovation. Manag Decis 58:812-827. https://doi.org/10.1108/MD-08-2018-0933

Tang Y, Hu X, Petti C, Thürer M (2020b) Institution-driven innovation in Guangdong firms: moderating effects of in-house formal R\&D and industrial environment turbulence. Sci Public Policy 47:194206. https://doi.org/10.1093/scipol/scz058

Tao Q, Jinchuan S (2008) Taizhou Model: Institutional Innovation and the Development of Private Economy. China World Econ 16:106-119. https://doi.org/10.1111/j.1749-124X.2008.00117.x

Thani FN, Mazari E, Asadi S, Mashayekhikhi M (2021) The impact of self-development on the tendency toward organizational innovation in higher education institutions with the mediating role of human resource agility. J Appl Res High Educ Ahead-of-P. https://doi.org/10.1108/ JARHE-05-2020-0151

Ting L, Xin CQ, Qian YQ (2020) The influence of collaborative innovation among technology, institution and finance on China's economic growth. WSEAS Trans Bus Econ 17:796-805. https://doi.org/10. $37394 / 23207.2020 .17 .78$

Tingey M, Webb J (2020) Governance institutions and prospects for local energy innovation: laggards and leaders among UK local authorities. Energy Policy. https://doi.org/10.1016/j.enpol.2019.111211

Tolbert CJ, Mossberger K, McNeal R (2008) Institutions, policy innovation, and e-government in the American States. Public Adm Rev 68:549-563. https://doi.org/10.1111/j.1540-6210.2008.00890.x

Tomizawa A, Zhao L, Bassellier G, Ahlstrom D (2020) Economic growth, innovation, institutions, and the Great Enrichment. Asia Pacific J Manag 37:7-31. https://doi.org/10.1007/s10490-019-09648-2

Torres de Oliveira R, Verreynne M-L, Figueira S et al (2020) How do institutional innovation systems affect open innovation? J Small Bus Manag. https://doi.org/10.1080/00472778.2020.1775466

Tumbas S, Berente N, vom Brocke J (2018) Digital innovation and institutional entrepreneurship: chief digital officer perspectives of their emerging role. J Inf Technol 33:188-202. https://doi.org/10. 1057/s41265-018-0055-0

Turker D, Vural CA (2017) Embedding social innovation process into the institutional context: Voids or supports. Technol Forecast Soc Change 119:98-113. https://doi.org/10.1016/j.techfore.2017.03. 019

Tyson LD (1979) Incentives, income sharing, and institutional innovation in the yugoslav self-managed firm. J Comp Econ 3:285-301. https://doi.org/10.1016/0147-5967(79)90030-1

Unger B, Zagler M (2003) Institutional and organizational determinants of product innovations. Innovation 16:293-310. https://doi.org/10.1080/1351161032000126035

Van Bockhaven WMG, Matthyssens P, Vandenbempt K (2015) Drivers of institutional innovation in networks: Unleashing the innovation potential of domesticated markets. J Bus Ind Mark 30:414-435. https://doi.org/10.1108/JBIM-10-2013-0220

van der Heijden J, Kuhlmann J (2017) Studying incremental institutional change: a systematic and critical meta-review of the literature from 2005 to 2015. Policy Stud J 45:535-554. https://doi.org/10. $1111 /$ psj.12191

van der Krabben E, Lenferink S (2018) The introduction of urban land readjustment legislation as an institutional innovation in Dutch land policy. Habitat Int 75:114-121. https://doi.org/10.1016/j. habitatint.2018.03.004

van Dijk S, Berends H, Jelinek M et al (2011) Micro-institutional affordances and strategies of radical innovation. Organ Stud 32:1485-1513. https://doi.org/10.1177/0170840611421253

van Waarden F (2001) Institutions and innovation: the legal environment of innovating firms. Organ Stud 22:765-795. https://doi.org/10.1177/0170840601225002

Van Wijk J, Van der Duim R, Lamers M, Sumba D (2015) The emergence of institutional innovations in tourism: the evolution of the African Wildlife Foundation's tourism conservation enterprises. J Sustain Tour 23:104-125. https://doi.org/10.1080/09669582.2014.927878

van Wijk J, Zietsma C, Dorado S et al (2019) Social innovation: integrating micro, meso, and macro level insights from institutional theory. Bus Soc 58:887-918. https://doi.org/10.1177/0007650318 789104 
Vasudeva G (2009) How national institutions influence technology policies and firms' knowledge-building strategies: A study of fuel cell innovation across industrialized countries. Res Policy 38:12481259. https://doi.org/10.1016/j.respol.2009.05.006

Vecchi A, Della Piana B, Vivacqua E (2015) An Institutional-based view of innovation - an explorative comparison of business groups in China and India. Int J Innov Manag. https://doi.org/10.1142/ S1363919615500516

Veiga PM, Teixeira SJ, Figueiredo R, Fernandes CI (2020) Entrepreneurship, innovation and competitiveness: a public institution love triangle. Socioecon Plann Sci. https://doi.org/10.1016/j.seps.2020. 100863

Velho L (2004) Building social science research capacity in Bolivia: an institutional innovation. Int Soc Sci J 56:257-270. https://doi.org/10.1111/j.0020-8701.2004.00488.x

Ventura R, Quero MJ, Díaz-Méndez M (2020) The role of institutions in achieving radical innovation. Mark Intell Plan 38:310-324. https://doi.org/10.1108/MIP-01-2019-0050

Venugopal S, Viswanathan M (2019) Implementation of social innovations in subsistence marketplaces: a facilitated institutional change process model. J Prod Innov Manag 36:800-823. https://doi.org/ 10.1111/jpim. 12508

Vermeulen P, Büch R, Greenwood R et al (2007a) The impact of governmental policies in institutional fields: the case of innovation in the Dutch concrete industry. Organ Stud 28:515-540. https://doi. org/10.1177/0170840606067927

Vermeulen PAM, Van Den Bosch FAJ, Volberda HW (2007b) Complex incremental product innovation in established service firms: a micro institutional perspective. Organ Stud 28:1523-1546. https:// doi.org/10.1177/0170840607068082

Vickers I, Lyon F, Sepulveda L, McMullin C (2017) Public service innovation and multiple institutional logics: The case of hybrid social enterprise providers of health and wellbeing. Res Policy 46:17551768. https://doi.org/10.1016/j.respol.2017.08.003

Villavicencio GJD, Didonet SR, Dodd A (2015) Innovation: an institutional approach. Espacios 36:13

Vines R, Jones M, McCarthy G (2015) Collaborating across institutional and jurisdictional boundaries: Enabling the emergence of a national innovation system through public knowledge management. Knowl Manag Res Pract 13:187-197. https://doi.org/10.1057/kmrp.2013.41

Waldorff SB (2013) Accounting for organizational innovations: mobilizing institutional logics in translation. Scand J Manag 29:219-234. https://doi.org/10.1016/j.scaman.2013.03.010

Wallman JP (2009) An examination of Peter Drucker's work from an institutional perspective: how institutional innovation creates value leadership. J Acad Mark Sci 37:61-72. https://doi.org/10.1007/ s11747-008-0104-2

Wang C, Alvarez-Gaitan JP, Moore S, Stuetz R (2019a) Social and institutional factors affecting sustainability innovation in universities: a computer re-use perspective. J Clean Prod 223:176-188. https:// doi.org/10.1016/j.jclepro.2019.03.093

Wang C, Yi J, Kafouros M, Yan Y (2015) Under what institutional conditions do business groups enhance innovation performance? J Bus Res 68:694-702. https://doi.org/10.1016/j.jbusres.2014.08.002

Wang H, Zhao Y, Dang B et al (2019b) Network centrality and innovation performance: the role of formal and informal institutions in emerging economies. J Bus Ind Mark 34:1388-1400. https://doi. org/10.1108/JBIM-09-2017-0228

Wang J, Deng J (2021) Research on the effect of executive incentive institutional innovation on the cost of equity—evidence from chinese listed companies. Front Psychol. https://doi.org/10.3389/fpsyg. 2021.686955

Wang L, Huang Z (2020) Research on the synergetic innovation between pharmaceutical enterprises and scientific research institutions based on the quantum game. IEEE Access 8:63718-63724. https:// doi.org/10.1109/ACCESS.2020.2976544

Wang P, Swanson EB (2007) Launching professional services automation: institutional entrepreneurship for information technology innovations. Inf Organ 17:59-88. https://doi.org/10.1016/j.infoandorg. 2007.02.001

Watkins A, Papaioannou T, Mugwagwa J, Kale D (2015) National innovation systems and the intermediary role of industry associations in building institutional capacities for innovation in developing countries: a critical review of the literature. Res Policy 44:1407-1418. https://doi.org/10.1016/j. respol.2015.05.004 
Watt DC (2002) The 'War' against terror and the need for institutional innovation. Polit Q 73:288-298. https://doi.org/10.1111/1467-923X.00469

Weber F, Lehmann J, Graf-Vlachy L, König A (2019) Institution-infused sensemaking of discontinuous innovations: the case of the sharing economy. J Prod Innov Manag 36:632-660. https://doi.org/10. 1111/jpim.12499

Webster A, Gardner J (2019) Aligning technology and institutional readiness: the adoption of innovation. Technol Anal Strateg Manag 31:1229-1241. https://doi.org/10.1080/09537325.2019.1601694

Whitley R (2014) How do institutional changes affect scientific innovations? the effects of shifts in authority relationships, protected space, and flexibility. Res Sociol Organ 42:367-406. https://doi. org/10.1108/S0733-558X20140000042012

Whitley R (2000) The institutional structuring of innovation strategies: business systems, firm types and patterns of technical change in different market economies. Organ Stud 21:855-886. https://doi. org/10.1177/0170840600215002

Widyani AAD (2019) Innovation and performance antecedents of village credit institutions in Bali province. J Manag Inf Decis Sci 22:101-106

Wiklund H, Klefsjö B, Wiklund PS, Edvardsson B (2003) Innovation and TQM in Swedish higher education institutions possibilities and pitfalls. TQM Mag 15:99-107. https://doi.org/10.1108/09544 780310461116

Williams ME (2002) Market reforms, technocrats, and institutional innovation. World Dev 30:395-412. https://doi.org/10.1016/S0305-750X(01)00116-4

Windrum P, Schartinger D, Waring J (2018) Co-creation of social innovations and new professional institutions: diffusion of therapeutic patient education (TPE) for diabetes in Austria. Ind Innov 25:570593. https://doi.org/10.1080/13662716.2017.1295363

Wiskerke JSC, Roep D (2007) Constructing a sustainable pork supply chain: a case of techno-institutional innovation. J Environ Policy Plan 9:53-74. https://doi.org/10.1080/15239080701254982

Woodhill J (2010) Capacities for institutional innovation: a complexity perspective. IDS Bull 41:47-59. https://doi.org/10.1111/j.1759-5436.2010.00136.x

Wu J (2013) Diverse institutional environments and product innovation of emerging market firms. Manag Int Rev 53:39-59. https://doi.org/10.1007/s11575-012-0162-Z

Wu J, Ma Z, Liu Z, Lei CK (2019) A contingent view of institutional environment, firm capability, and innovation performance of emerging multinational enterprises. Ind Mark Manag 82:148-157. https://doi.org/10.1016/j.indmarman.2019.01.018

Wu J, Park SH (2019) The role of international institutional complexity on emerging market multinational companies' innovation. Glob Strateg J 9:333-353. https://doi.org/10.1002/gsj.1166

Wu J, Wang C, Hong J et al (2016) Internationalization and innovation performance of emerging market enterprises: The role of host-country institutional development. J World Bus 51:251-263. https:// doi.org/10.1016/j.jwb.2015.09.002

Wu J, Wu Z, Zhuo S (2015) The effects of institutional quality and diversity of foreign markets on exporting firms' innovation. Int Bus Rev 24:1095-1106. https://doi.org/10.1016/j.ibusrev.2015.05.001

Wu Y, Yang Y, Xu W, Chen Q (2020) The influence of innovation resources in higher education institutions on the development of Sci-tech parks' enterprises in the urban innovative districts at the stage of urbanization transformation. Land 9:1-36. https://doi.org/10.3390/land9100396

Xie A (2006) Institutional innovation and systematic construction of teacher education in the transformational period. Front Educ China 1:201-211. https://doi.org/10.1007/s11516-006-0003-6

Xie J, Yang Y (2021) IoT-based model for intelligent innovation practice system in higher education institutions. J Intell Fuzzy Syst 40:2861-2870. https://doi.org/10.3233/JIFS-189326

Xie X, Wu Y, Xie P et al (2019) Organizational innovation culture and firms' new product performance in two emerging markets: The moderating effects of institutional environments and organizational cohesion. J Manag Organ. https://doi.org/10.1017/jmo.2019.8

Xu H, Wang C, Dong K et al (2020) A study of methods to identify industry-university-research institution cooperation partners based on innovation Chain theory. J Data Inf Sci 3:38-61. https://doi.org/ 10.2478/jdis-2018-0008

Yang D, Jiao H, Buckland R (2017) The determinants of financial fraud in Chinese firms: does corporate governance as an institutional innovation matter? Technol Forecast Soc Change 125:309-320. https://doi.org/10.1016/j.techfore.2017.06.035

Yang D, Wang AX, Zhou KZ, Jiang W (2019) Environmental strategy, institutional force, and innovation capability: a managerial cognition perspective. J Bus Ethics 159:1147-1161. https://doi.org/ 10.1007/s10551-018-3830-5 
Yang G (2018) The cost of institutional innovation in the absence of an external governance mechanism—a case study on the 'Alibaba Partnership.' China J Account Stud 6:498-526. https://doi.org/ $10.1080 / 21697213.2019 .1612192$

Yang J, Al-Sayed R (2021) Barriers to radical innovation in research institutions in China. Int J Innov Sci Ahead-of-P. https://doi.org/10.1108/IJIS-04-2021-0075

Yang K (2016) Creating Public Value and Institutional Innovations across Boundaries: An Integrative Process of Participation, Legitimation, and Implementation. Public Adm Rev 76:873-885. https:// doi.org/10.1111/puar.12561

Yano G, Shiraishi M (2020) Finance, institutions, and innovation activities in China. Econ Syst. https:// doi.org/10.1016/j.ecosys.2020.100835

Yao Q, Liu J, Sheng S, Fang H (2019) Does eco-innovation lift firm value? The contingent role of institutions in emerging markets. J Bus Ind Mark 34:1763-1778. https://doi.org/10.1108/ JBIM-06-2018-0201

Yao Q, Zeng S, Sheng S, Gong S (2021) Green innovation and brand equity: moderating effects of industrial institutions. Asia Pacific J Manag 38:573-602. https://doi.org/10.1007/s10490-019-09664-2

Yau Y, Lau W (2018) Big data approach as an institutional innovation to Tackle Hong Kong's illegal subdivided unit problem. Sustainability 10:2709. https://doi.org/10.3390/su10082709

Yeung SM-C (2015) Innovation in the application of gri to visualize strategic goals for sustainable development - The case of tertiary institution, Hong Kong. Corp Ownersh Control 12:572-585

Yi J, Hong J, Hsu WC, Wang C (2017) The role of state ownership and institutions in the innovation performance of emerging market enterprises: evidence from China. Technovation 62-63:4-13. https:// doi.org/10.1016/j.technovation.2017.04.002

Yi Y, Liu Y, He H, Li Y (2012) Environment, governance, controls, and radical innovation during institutional transitions. Asia Pacific J Manag 29:689-708. https://doi.org/10.1007/s10490-010-9231-7

Yingbo L, Jiankun H, Li Z (2010) The transfer of innovation capability from universities to enterprises in China: An institutional framework. Int J Manag Enterp Dev 9:385-404. https://doi.org/10.1504/ IJMED.2010.037565

Yoshikawa T, Tsui-Auch LS, McGuire J (2007) Corporate governance reform as institutional innovation: The case of Japan. Organ Sci 18:973-988. https://doi.org/10.1287/orsc.1070.0290

Yu X, Paudel KP, Li D et al (2020) Sustainable collaborative innovation between research institutions and seed enterprises in China. Sustain. https://doi.org/10.3390/su12020624

Yu Z (2020) Beyond the state/market dichotomy: institutional innovations in China's electricity industry reform. J Environ Manage. https://doi.org/10.1016/j.jenvman.2020.110306

Zapata-Cantu L, González F (2021) Challenges for innovation and sustainable development in Latin America: the significance of institutions and human capital. Sustainability 13:4077. https://doi.org/ $10.3390 /$ su13074077

Zhang K, Putzel L (2016) Institutional innovation and forest landscape restoration in China: Multi-scale cross-sector networking, household fiscal modernization and tenure reform. World Dev Perspect 3:18-21. https://doi.org/10.1016/j.wdp.2016.11.002

Zhang Y, Tan W (2019) The leading small group: an institutional innovation for PPP projects in China. Built Environ Proj Asset Manag 9:291-301. https://doi.org/10.1108/BEPAM-12-2017-0132

Zhu Y, Wittmann X, Peng MW (2012) Institution-based barriers to innovation in SMEs in China. Asia Pacific J Manag 29:1131-1142. https://doi.org/10.1007/s10490-011-9263-7

Zweifel P (1995) Diffusion of hospital innovations in different institutional settings. Int J Econ Bus 2:465-483. https://doi.org/10.1080/758538017

Publisher's Note Springer Nature remains neutral with regard to jurisdictional claims in published maps and institutional affiliations. 